$11-1996$

\title{
Cultural Resources Survey of the Leander Rehabilitation Center, Williamson County, Texas
}

Diane E. Williams

Prewitt and Associates, Inc.

Martha Doty Freeman

Prewitt and Associates, Inc.

Marie E. Blake

Prewitt and Associates, Inc.

Karl W. Kibler

Cross Timbers Geoarcheological Services

Paul J. Maslyk

Prewitt and Associates, Inc.

Follow this and additional works at: https://scholarworks.sfasu.edu/ita

Part of the American Material Culture Commons, Archaeological Anthropology Commons, Environmental Studies Commons, Other American Studies Commons, Other Arts and Humanities Commons, Other History of Art, Architecture, and Archaeology Commons, and the United States History Commons

Tell us how this article helped you.

This Article is brought to you for free and open access by the Center for Regional Heritage Research at SFA ScholarWorks. It has been accepted for inclusion in Index of Texas Archaeology: Open Access Gray Literature from the Lone Star State by an authorized editor of SFA ScholarWorks. For more information, please contact cdsscholarworks@sfasu.edu. 


\section{Cultural Resources Survey of the Leander Rehabilitation Center, Williamson County, Texas}

\section{Creative Commons License}

\section{(c) (1) $\Theta$}

This work is licensed under a Creative Commons Attribution-NonCommercial-No Derivative Works 4.0 International License. 


\section{CULTURAi: RESOURCES SURVEY}

OF THE LEANDER REHABILITATION CENTER, WILLIAMSON COUNTY, TEXAS

by

Diane E. Williams

Marthe Doty Freemin

Marie E. Blake

Karl W. Kibler

and

Paul J. Maslyk

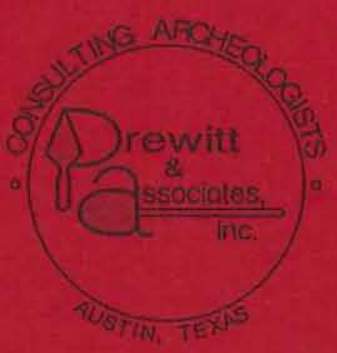

RERORTS OF.IINVESTIGATIONS, NUMABIR I13

Trexas Antroutries COMmitTeg Archeology Permit no. 1725 


\title{
CULTURAL RESOURCES SURVEY OF THE LEANDER REHABILITATION CENTER, WILLIAMSON COUNTY, TEXAS
}

\author{
by \\ Diane E. Williams \\ Martha Doty Freeman \\ Marie E. Blake \\ Karl W. Kibler \\ and \\ Paul J. Maslyk
}

Co-Principal Investigators: Elton R. Prewitt and Karl W. Kibler

REPORTS OF INVESTIGATIONS, NUMBER 113

Submitted to

Carter and Burgess, Inc.

Austin, Texas

by

Prewitt and Associates, Inc.

Consulting Archeologists

Austin, Texas

November 1996

TEXAS ANTIQUITIES COMMITTËE ARCHEEOLOGY PERMIT NO. 1725 



\section{TABLE OF CONTENTS}

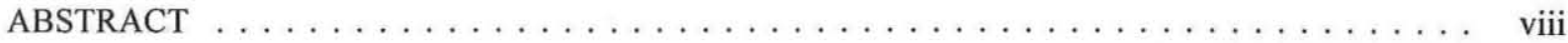

ACKNOWLEDGMENTS $\ldots \ldots \ldots \ldots \ldots \ldots \ldots \ldots \ldots \ldots \ldots \ldots \ldots \ldots \ldots \ldots \ldots$

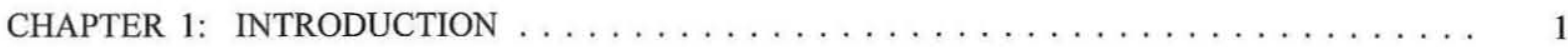

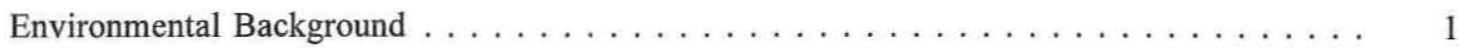

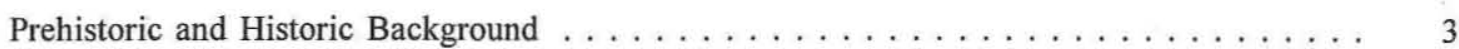

Prehistoric Period ....................... 3

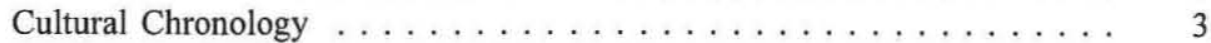

Previous Archeological Investigations in the

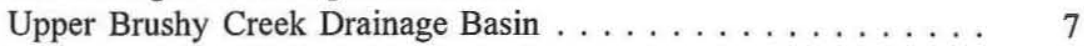

Historical Overview . . . . . . . . . . . . . . . . . . 8

The Samuel Damon and Rachel Saul Surveys before $1942 \ldots \ldots$. . . 8

Planning, Acquisition, and Development of the State

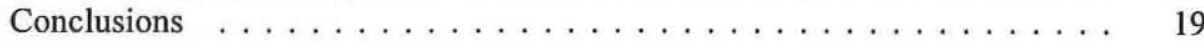

Dairy and Hog Farm $\ldots \ldots \ldots \ldots \ldots \ldots \ldots \ldots \ldots \ldots$

CHAPTER 2: METHODS OF INVESTIGATIONS $\ldots \ldots \ldots \ldots \ldots \ldots \ldots \ldots \ldots \ldots \ldots$

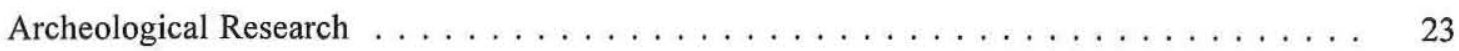

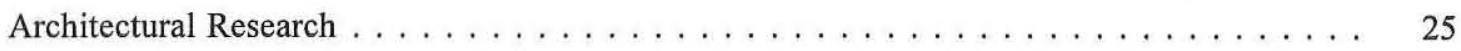

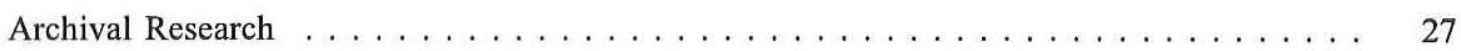

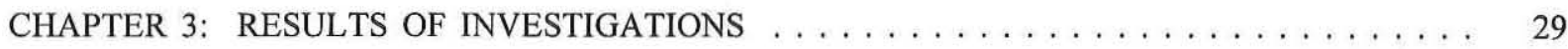

Archeological Sites . . . . . . . . . . . . . . . . . . . . . . . . . . 29

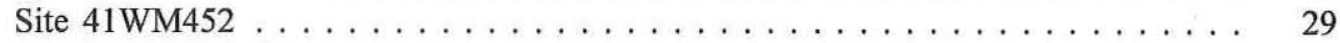

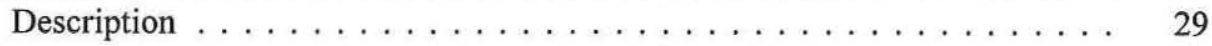

Cultural Materials Observed and Collected . . . . . . . . . . . 29

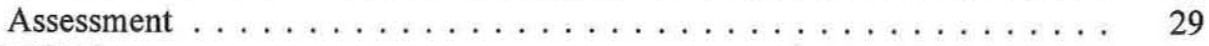

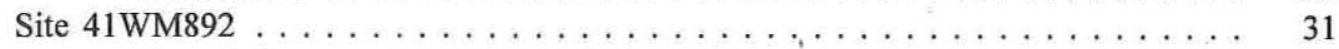

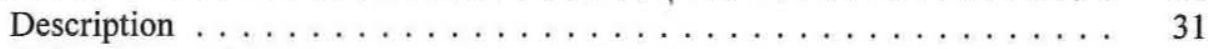

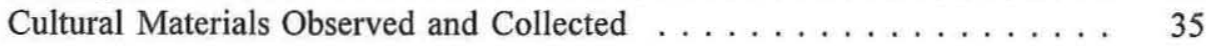

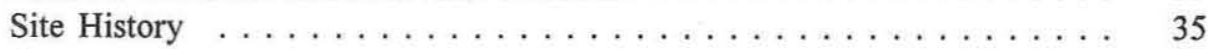

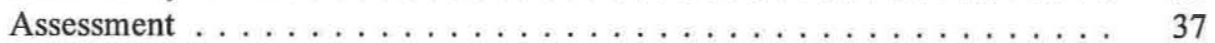

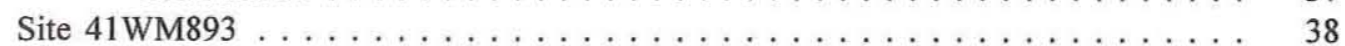

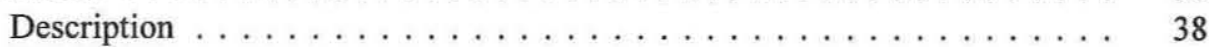

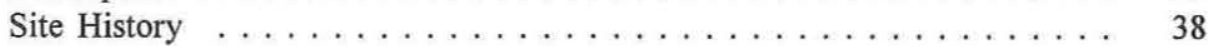

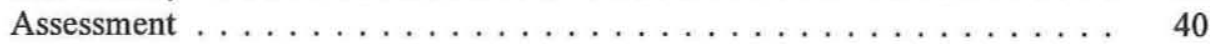

Site 41 WM896, Rhodes Farm . . . . . . . . . . . . . . . . 40

Description . . . . . . . . . . . . . . . . . 40

Cultural Materials Observed and Collected ............ 41

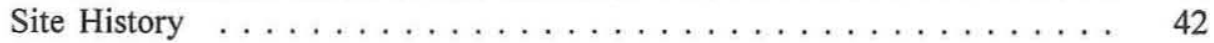

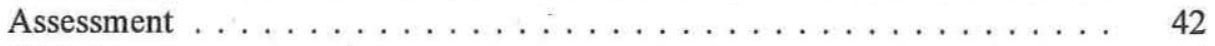

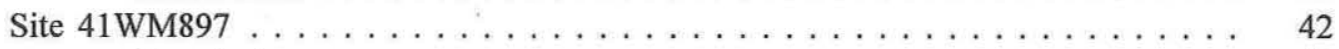

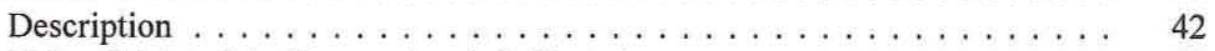

Cultural Materials Observed and Collected . . . . . . . . . . . 43

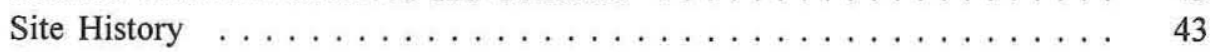

Assessment . . . . . . . . . . . . . . . . . . . . . . 44 


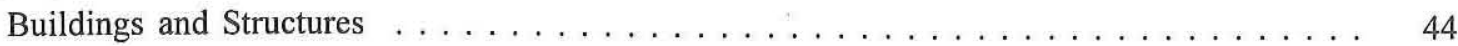

Historic Resource No. 1, Storekeeper/Accountant's Office and Warehouse . . . . . . 44

Historic Resource No. 2a, Superintendent's House . . . . . . . . . . . . . . . . . 46

Historic Resource No. 2b, Superintendent's Garage . . . . . . . . . . . . . . . . . 47

Historic Resource No. 3, Storekeeper/Accountant's Residence . . . . . . . . . . . . . 48

Historic Resource No. 4, Dairyman's Residence . . . . . . . . . . . . . . . . . . 49

Historic Resource No. 5, Maintenance Barn . . . . . . . . . . . . . . . . 50

Historic Resource No. 6a, Hay Barn and Implement Shed . . . . . . . . . . . . 51

Historic Resource No. 6b, Truck Scale . . . . . . . . . . . . . . . . . . 51

Historic Resources Nos. 7, 9, and 16, Water Troughs . . . . . . . . . 52

Historic Resource No. 8, Water Fountain . . . . . . . . . . . . . . . 53

Historic Resource No. 10, Bull Barn . . . . . . . . . . . . . . . . . 53

Historic Resource No. 11, Mule Barn . . . . . . . . . . . . . . . . . . 54

Historic Resources Nos. 12, 13, and 14, Calf Feeder Sheds . . . . . . . . . 54

Historic Resource No. 15, Feed Trough . . . . . . . . . . . . . . . . . 55

Historic Resource No. 17, Fence . . . . . . . . . . . . . . . . . . . 56

Historic Resources Nos. 18-20 and 22-24, Group Sheds/Dormitories . . . . . . . 56

Historic Resource No. 21, Kitchen, Laundry, and Restroom . . . . . . . . . . . 57

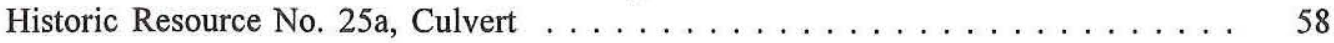

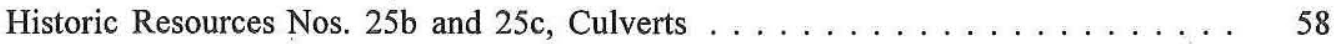

Historic Resource No. 26, Water Trough . . . . . . . . . . . . . . . . . . 58

Historic Resources Nos. 27 and 30, Pole Barns/Group Sheds . . . . . . . . . . 59

Historic Resource No. 28, Fencing Foundation . . . . . . . . . . . . . 60

Historic Resources Nos. 29 and 31, Feed Troughs . . . . . . . . . . . . . . 60

Historic Resource No. 32a, Swineherd Residence . . . . . . . . . . . . . . . . 61

Historic Resource No. 32b, Sheep Dip Tank . . . . . . . . . . . . . . . 62

Historic Resource No. 32c, Water Trough . . . . . . . . . . . . . . . . . . 62

Historic Resource No. 32d, Feed Trough . . . . . . . . . . . . . . . . . . 63

Historic Resource No. 32e, Water Trough . . . . . . . . . . . . . . . . . . . 63

Historic Resource No. 32f, Water Trough . . . . . . . . . . . . . . . . . . . . . 64

Historic Resource No. 33, Kitchen, Dining Room, and Dormitory . . . . . . . . . . 64

Historic Resource No. 34, Sewage Treatment Facility . . . . . . . . . . . . . . . . 65

Historic Resource No. 35, Sewer Pipe . . . . . . . . . . . . . . . . . . 66

Historic Resource No. 36, Livestock Chute . . . . . . . . . . . . . . . . . . 67

CHAPTER 4: ASSESSMENTS AND RECOMMENDATIONS $\ldots \ldots \ldots \ldots \ldots \ldots \ldots$

Archeological Resources . . . . . . . . . . . . . . . . . . . . . . . 69

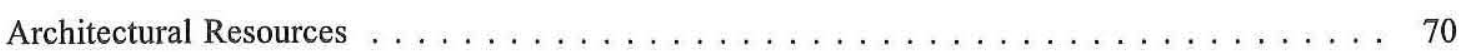

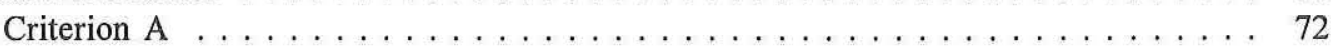

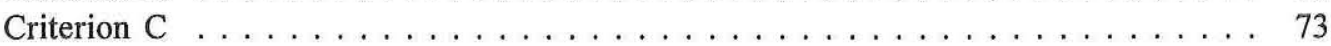

Mitigation Recommendations . . . . . . . . . . . . . . . . . 74

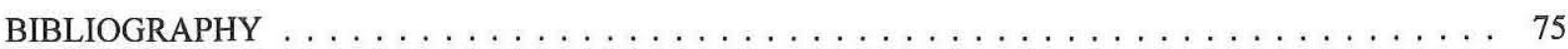

APPENDIX: Inventory of Buildings and Structures $\ldots \ldots \ldots \ldots \ldots \ldots \ldots \ldots \ldots \ldots$ 


\section{LIST OF FIGURES}

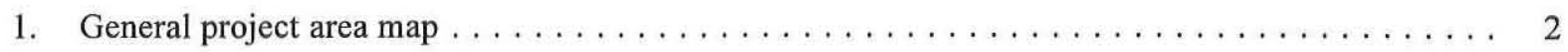

2. Comparison of prehistoric cultural sequences $\ldots \ldots \ldots \ldots \ldots \ldots \ldots \ldots \ldots \ldots \ldots$

3. Property transactions involving the N. J. Dedear tract, $1837-1942 \ldots \ldots \ldots \ldots \ldots \ldots \ldots \ldots$

4. Property transactions involving the T. W. Rhodes, E. D. Rhodes, and LCRA tracts, 1837-1945 _. 10

5. Historic properties at the State Dairy and Hog Farm, $1945 \ldots \ldots \ldots \ldots \ldots \ldots \ldots \ldots$

6. Historic properties at the State Dairy and Hog Farm, $1950 \ldots \ldots \ldots \ldots \ldots \ldots \ldots \ldots$

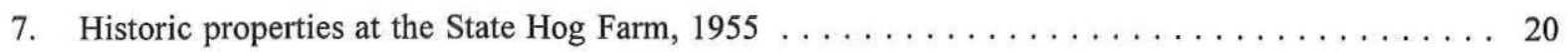

8. Areas of high, moderate, and low prehistoric site probability $\ldots \ldots \ldots \ldots \ldots \ldots \ldots \ldots 24$

9. Archeological sites and off-site shovel test locations $\ldots \ldots \ldots \ldots \ldots \ldots \ldots \ldots \ldots \ldots$

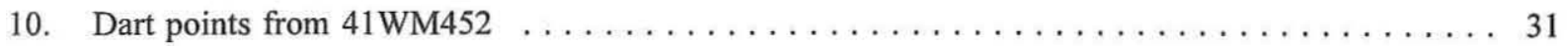

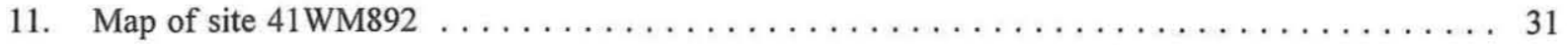

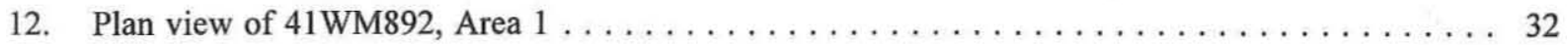

13. Photograph of stone enclosure in Area 1 of 41 WM892 $\ldots \ldots \ldots \ldots \ldots \ldots \ldots \ldots \ldots \ldots$

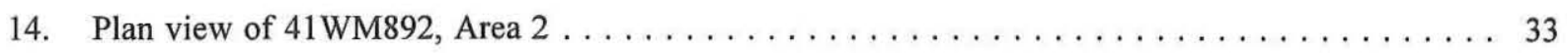

15. Photograph of stone enclosure in Area 2 of 41 WM892 $\ldots \ldots \ldots \ldots \ldots \ldots \ldots \ldots \ldots$

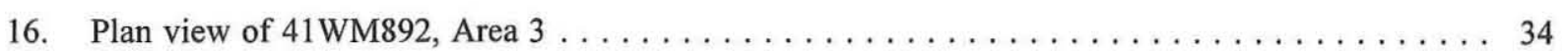

17. Plat and field notes of M. C. Hamilton's subdivision of a portion of the Rachel Saul League . . . 36

18. Photograph of railroad bed with exposed gravels, site 41 WM893 $\ldots \ldots \ldots \ldots \ldots \ldots \ldots$

19. Map of site 41 WM896, the Rhodes farm $\ldots \ldots \ldots \ldots \ldots \ldots \ldots \ldots \ldots \ldots \ldots \ldots \ldots \ldots \ldots$

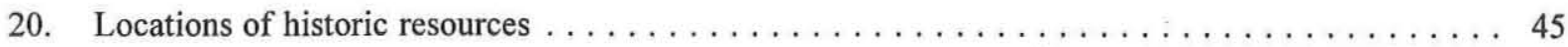

21. Photograph of Historic Resource No. 1, storekeeper/accountant's office and warehouse . . . . . 46

22. Photograph of Historic Resource No. 2a, Superintendent's house $\ldots \ldots \ldots \ldots \ldots \ldots \ldots \ldots$

23. Photograph of Historic Resource No. 2b, Superintendent's garage $\ldots \ldots \ldots \ldots \ldots \ldots \ldots$

24. Photograph of Historic Resource No. 3, storekeeper/accountant's residence . . . . . . . . . . . 49

25. Photograph of Historic Resource No. 4, dairyman's residence . . . . . . . . . . . . . . . 49

26. Photograph of Historic Resource No. 5, maintenance barn $\ldots \ldots \ldots \ldots \ldots \ldots \ldots \ldots \ldots$

27. Photograph of Historic Resource No. 6a, hay barn and implement shed $\ldots \ldots \ldots \ldots \ldots \ldots$

28. Photograph of Historic Resource No. $6 \mathrm{~b}$, truck scale, $\ldots \ldots \ldots \ldots \ldots \ldots \ldots \ldots \ldots \ldots$

29. Photograph of Historic Resources No. 7 and 9, water troughs $\ldots \ldots \ldots \ldots \ldots \ldots \ldots \ldots \ldots \ldots \ldots \ldots \ldots \ldots$

30. Photograph of Historic Resource No. 8, water fountain $\ldots \ldots \ldots \ldots \ldots \ldots \ldots \ldots \ldots \ldots$

31. Photograph of Historic Resource No. 10, bull barn $\ldots \ldots \ldots \ldots \ldots \ldots \ldots \ldots \ldots \ldots \ldots \ldots \ldots \ldots \ldots \ldots$

32. Photograph of Historic Resource No. 11, mule barn $\ldots \ldots \ldots \ldots \ldots \ldots \ldots \ldots \ldots \ldots$

33. Photograph of Historic Resources Nos. 12, 13, and 14, calf feeder sheds $\ldots \ldots \ldots \ldots \ldots$ 
34. Photograph of Historic Resource No. 15, feed trough $\ldots \ldots \ldots \ldots \ldots \ldots \ldots \ldots \ldots \ldots$

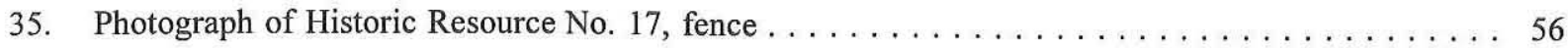

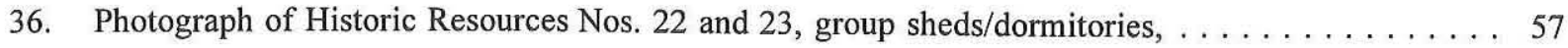

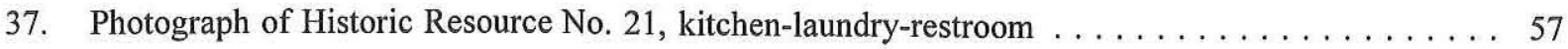

38. Photograph of Historic Resource No. 25a, culvert $\ldots \ldots \ldots \ldots \ldots \ldots \ldots \ldots \ldots \ldots \ldots$

39. Photograph of Historic Resource No. 26, water trough $\ldots \ldots \ldots \ldots \ldots \ldots \ldots \ldots \ldots$

40. Photograph of Historic Resources Nos. 27 and 30, pole barns/group sheds, . . . . . . . . . 60

41. Photograph of Historic Resource No. 28, fencing foundation $\ldots \ldots \ldots \ldots \ldots \ldots \ldots \ldots$

42. Photograph of Historic Resource No. 29, feed trough $\ldots \ldots \ldots \ldots \ldots \ldots \ldots \ldots \ldots \ldots$

43. Photograph of Historic Resource No. 32a, swineherd residence $\ldots \ldots \ldots \ldots \ldots \ldots \ldots \ldots \ldots$

44. Photograph of Historic Resource No. 32b, sheep dip tank $\ldots \ldots \ldots \ldots \ldots \ldots \ldots \ldots \ldots \ldots$

45. Photograph of Historic Resource No. 32c, water trough $\ldots \ldots \ldots \ldots \ldots \ldots \ldots \ldots \ldots \ldots$

46. Photograph of Historic Resource No. 32d, feed trough $\ldots \ldots \ldots \ldots \ldots \ldots \ldots \ldots \ldots \ldots \ldots \ldots \ldots \ldots$

47. Photograph of Historic Resource No. 32e, water trough $\ldots \ldots \ldots \ldots \ldots \ldots \ldots \ldots \ldots \ldots$

48. Photograph of Historic Resource No. 32f, water trough $\ldots \ldots \ldots \ldots \ldots \ldots \ldots \ldots \ldots \ldots$

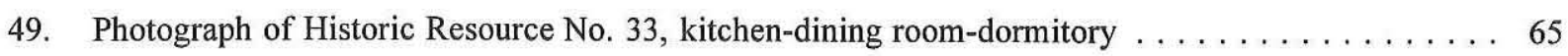

50. Photograph of Historic Resource No. 34, sewage treatment facility $\ldots \ldots \ldots \ldots \ldots \ldots \ldots$

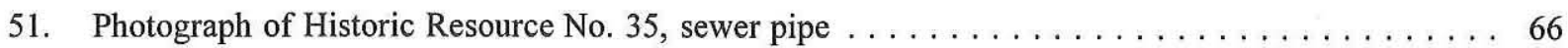

52. Photograph of Historic Resource No. 36, livestock chute $\ldots \ldots \ldots \ldots \ldots \ldots \ldots \ldots \ldots$

53. Recommended State Dairy and Hog Farm Administrative, Residential, and

Dairy Operations Historic District $\ldots \ldots \ldots \ldots \ldots \ldots \ldots \ldots \ldots \ldots \ldots \ldots \ldots \ldots \ldots$ 


\section{LIST OF TABLES}

1. State Diary and Hog Farm inventory, August $31,1948 \ldots \ldots \ldots \ldots \ldots \ldots \ldots \ldots \ldots \ldots$

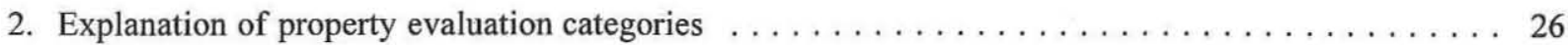

3. Contributing resources within the State Dairy and Hog Farm Administrative, Residential,

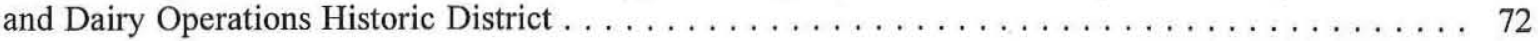




\begin{abstract}
In August-September 1996, personnel from Prewitt and Associates, Inc., conducted a cultural resources survey of ca. 725 acres of the former Leander Rehabilitation Center. The project area lies adjacent to U.S. Highway 183 and FM 620 in southern Williamson County, Texas. The survey resulted in additional documentation of one previously recorded prehistoric archeological site (41WM452), the identification and recording of four historic archeological sites (41WM892, 41WM893, 41WM896, and 41WM897), and reconnaissance-level documentation of 45 historic buildings and structures.

Site 41WM452 is an extensive upland lithic scatter and lithic procurement site which lacks subsurface deposits, features, and datable materials. Site 41WM892 is a wood-chopper camp that contains a number of rock alignments and limited artifact deposits dating to the first decade of the twentieth century. Site 41WM893 is a remnant of a railroad spur used during the 1937-1941 construction of Marshall Ford Dam (now Mansfield Dam). Site 41WM896 contains a small number of features and sparse artifact deposits associated with the 1937-1945 Rhodes farmstead. Site 41 WM897 is an isolated historic well with unknown associations. None of these archeological sites contains important information, and it is recommended that they be considered not eligible for listing in the National Register of Historic Places or for designation as State Archeological Landmarks.

The 45 buildings and structures, at 36 locations, are associated with the former State Dairy and Hog Farm. This farm was established in 1942, expanded after 1945, and reached its peak years of production as a hog farm between 1950 and the late 1960s. Created to serve the needs of the State Board of Control and the State Hospital, the facility is significant for its success in food production for eleemosynary institutions in Austin and throughout Texas, as well as for its role in the application of modern psychiatric treatment based on the therapeutic value of manual labor. Among the surveyed resources are dwellings, an office and warehouse building, a dormitory, a variety of agricultural buildings and structures, and infrastructural elements, all built between 1943 and 1955. Twenty-one of the 45 surveyed resources are recommended as being eligible for listing in the National Register of Historic Places under Criteria A and C as Contributing resources in a historic district and for designation as State Archeological Landmarks.
\end{abstract}




\section{ACKNOWLEDGMENTS}

Many individuals, agencies, and organizations are responsible for the successful completion of this project. The archeological field crew of Joan Baker and Kyle Killian performed admirably, despite the heavy juniper undergrowth and August heat. The field crew was directed by Project Archeologist Paul Maslyk and Project Historical Archeologist Marie E. Blake. Diane E. Williams served as Project Architectural Historian and Martha D. Freeman served as Project Historian.

The following individuals or groups of individuals are recognized for their valuable contributions to the project. Hank B. Smith, P.E., of Carter and Burgess, Inc., served as the overall Project Manager and provided copies of project area maps and legal plats. Bob Skiles, Staff Archeologist at the General Land Office, supplied various historic maps, aerial photographs, and invaluable assistance throughout the project. Roy Molina, Assistant Director of the General Land Office Surveying Division, coordinated the mapping of one archeological site (41WM892) and supervised the surveying crew consisting of Elisondro Leos, David Holmes, Willie Miles, Charlie Strauch, and Mike McKarzel. Cynthia Gerken, Planner in the Asset Management Division of the General Land Office, also provided valuable support and assistance throughout the project. Myles Miller of the Texas Historical Commission provided advice and approved the scope of work for the archeological survey. Roy Jones, facilities manager at the Texas Mental Health and Mental Retardation Department, provided access to plans and drawings for the Leander Rehabilitation Center as well as contact with Elaine Albritton, daughter of former State Dairy and Hog Farm business manager Leonard Wynn. Mr. and Mrs. Leonard Wynn and Elaine Albritton supplied important information on the development, use, and history of the facility between 1945 and 1970. Sam Richards of the Department of Mental Health and Mental Retardation also provided access to important files and documents. Robert N. Williams, retired Civil Engineer, provided information on the history, application, and significance of the Imhoff tank septic system. Joe C. Freeman, AIA, supplied data on cavity-wall construction and septic systems. The staffs at the following agencies and organizations are also recognized for their support and assistance: the Archives and Records and Surveying Divisions at the General Land Office, the Archives Division at the Texas State Library and Archives (who made available the records of the State Board of Control), the Williamson County Clerk's office, The Williamson County Sun (who provided microfilm copies of the newspaper), the Center for American History at The University of Texas at Austin, and the Austin History Center.

The staff at Prewitt and Associates, Inc., provided help throughout all stages of this project. Elton R. Prewitt and Karl W. Kibler served as Co-Principal Investigators. Karl also conducted a reconnaissance-level geomorphic study of the project area. Karen M. Gardner provided assistance with obtaining archeological site numbers and coordinated the laboratory efforts. Ellen Atha illustrated the artifacts depicted in this report. Sandra L. Hannum and Brian J. Wootan drafted the maps and figures. Ross C. Fields and Melissa C. Hennigan had the task of editing and integrating the products of several authors into a coherent report. Linda Foster did a final edit and produced the report. 


\section{.}




\section{INTRODUCTION}

This report presents the results of Phase I cultural resource investigations of approximately 725 acres of the former Leander Rehabilitation Center, Texas Department of Mental Health and Mental Retardation, in south-central Williamson County, Texas (Figure 1). These investigations included an archeological survey, archival and historic research, and an historic architectural survey. They were conducted by Prewitt and Associates, Inc., in August 1996 under a subcontract with Carter and Burgess, Inc., of Austin, Texas. The project area is bounded generally by South Brushy Creek on the north, the Southern Pacific Railroad on the east, U.S. Highway 183 on the west, and FM 620 on the south. Currently, the property is state-owned land administered jointly by the Texas General Land Office (GLO) and the Texas Department of Transportation (TxDOT). Within the project area are remnants of facilities known originally as the State Dairy and Hog Farm and later as the Leander Rehabilitation Center.

Although final plans for the disposition of the former Leander Rehabilitation Center property are not yet solidified, it is known that most of the project area is slated for eventual sale and/or development and that some of the future developments will likely inolve federal funding or permitting. Consequently, cultural resource investigations are required under Section 106 of the National Historic Preservation Act of 1966 (P.L. 89-665, as amended) and the applicable federal standards outlined in Protection of Historic Properties (36 C.F.R. 800) and the National Register of Historic Places (36 C.F.R. $60)$. Because the GLO and TxDOT are units of state government, the investigations were conducted under Texas Antiquities Committee Archeology Permit No. 1725 to comply with the Texas Antiquities Code. All buildings and structures and archeo- logical sites are evaluated in terms of their eligibility for listing in the National Register of Historic Places and for designation as State Archeological Landmarks.

The remaining portion of this chapter contains environmental and cultural background information. Chapter 2 outlines the methods of investigations, while Chapter 3 presents the results of the investigations. The final chapter states assessments and recommendations regarding the documented cultural resources.

\section{ENVIRONMENTAL BACKGROUND}

The project area is located within the Jollyville Plateau, a physiographic unit assigned to either the Edwards Plateau (Garner and Young 1976:5) or the Lampasas Cut Plain of the Grand Prairie (Hill 1901:79; Johnson 1931:125). The Balcones Escarpment, which forms the western border of the Blackland Prairie, is approximately $8 \mathrm{~km}$ to the east. The project area is situated within the upper Brushy Creek drainage basin on an upland divide between South Brushy Creek on the north and Lake Creek on the south.

Over 95 percent of the project area is characterized by level to moderately sloping and generally undissected upland plateau surfaces. The upland plateau consists of limestones of the Edwards Formation of the Lower Cretaceous Fredericksburg Group (Barnes 1981; Garner and Young 1976:Plate VII, 33-35). The upland surfaces are mantled with thin, patchy accumulations of gravelly clay and silt, upon which thin gravelly clay and silty Mollisols of the Eckrant-Georgetown soil associations have formed (Werchan and Coker 1983). Residual chert pebbles and cobbles are common in these shallow 


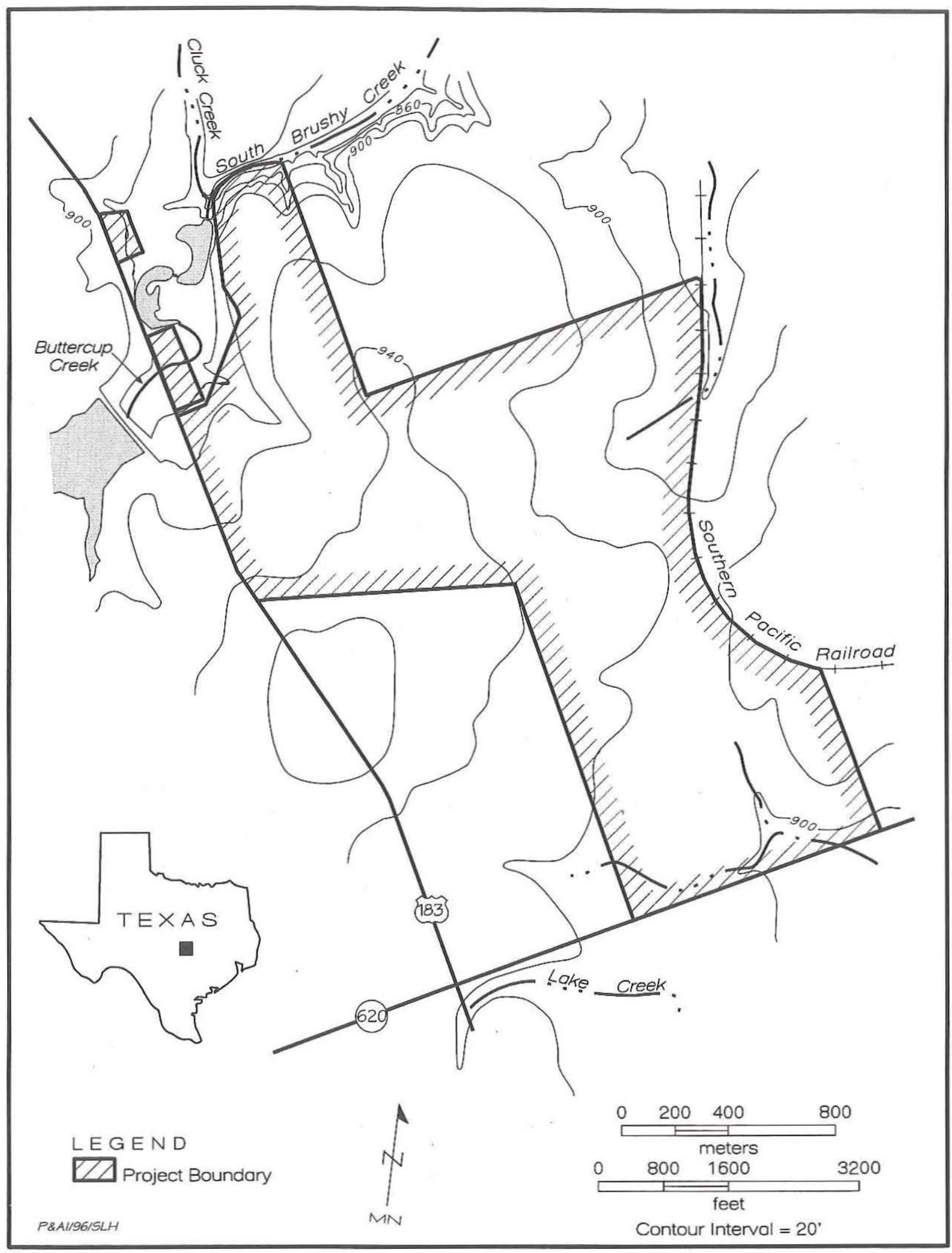

Figure 1. General project area map. 
soils and on exposed bedrock.

The northern margin and portions of the northwestern margin of the project area extend into the South Brushy Creek and Buttercup Creek valleys. These areas make up less than ca. 5 percent of the total project area and consist of deeply entrenched, small, gravelly, braided streams. Much of the Buttercup Creek valley has been modified due to quarrying activities and the impoundment of water above its confluence with Cluck Creek. Exposures of late Quaternary alluvium in the Buttercup Creek valley reveal a thick gravelly fill mantled by a thin drape (ca. 40-60 cm) of dark brown gravelly silt. Late Quaternary fill within the South Brushy Creek valley exists under two small constructional surfaces. The lowest surface, $\mathrm{T}_{0}$, consists of longitudinal gravel bars and gravel clasts shed from the bordering limestone escarpment. The higher surface, $\mathrm{T}_{1}$, is ca. $3 \mathrm{~m}$ above the channel. Only small narrow remnants of this surface exist. The fill below the $T_{1}$ surface consists primarily of gravelly, silty clay loam.

The modern vegetation in the project area is oak savannah with scattered thickets of live oaks and scrub oaks (Johnson 1931). This is probably not an accurate representation of the prehistoric floral communities because of extensive alterations during historic times. The eastern portion of the Edwards Plateau supports a diversity of fauna characteristic of the Balconian biotic province (Blair 1950:112-115). Like the flora, the fauna have been significantly impacted by historic activities and modern development in the immediate vicinity.

\section{PREHISTORIC AND HISTORIC BACKGROUND}

\section{Prehistoric Period}

\section{Cultural Chronology}

The prehistoric cultural sequence for the upper Brushy Creek basin follows schemes devised for the larger region of Central Texas. This sequence can be divided into three broad periods: Paleoindian, Archaic, and Late Prehistoric, although the terms Neoarchaic (Prewitt 1981, 1985) and Post-Archaic (Johnson and Goode 1994) have been used at times in place of the term Late Prehistoric. Prewitt's (1981, 1985) prehistoric cultural-historical framework, which incorporates discrete temporal and technological units (i.e., phases), is used by many researchers, but recently revised chronologies have been proposed by Johnson and Goode (1994) and Collins (1995). These revised chronologies do not use the term "phase" to describe cultural-historical units, and instead have opted for named "intervals" or "patterns" based on diagnostic projectile point styles and associated radiocarbon assays (e.g., Martindale-Uvalde interval of the Early Archaic period) within each period or subperiod. These three cultural chronologies are compared in Figure 2.

The Paleoindian period (11,500-8800 B.P.) represents the earliest known cultural manifestation in North America. Sites and isolated artifacts of this period are fairly common across Central Texas. The period is often described as having been characterized by small but highly mobile bands of foragers who were specialized hunters of Pleistocene megafauna. However, a more accurate view of Paleoindian lifeways includes the utilization of a much wider array of subsistence resources. Recent investigations at the nearby Wilson-Leonard site (41WM235) support this view and have challenged the fundamental defining criteria, that of artifacts in association with late Pleistocene megafauna, of the Paleoindian period (Masson and Collins 1995).

Environmental conditions during the Paleoindian period were quite different than today, presenting the early inhabitants with a much different array of resources. Nordt et al. (1994) view this period as a transition between cooler and moister late Pleistocene conditions and warmer and drier Holocene conditions. They estimate that warm season, or $\mathrm{C}_{4}$, grasses steadily increased in number throughout this period. Toomey et al. (1993) also see this time as a period of transition, with summer temperatures increasing rapidly but remaining $2-3^{\circ} \mathrm{C}$ below modern values. Toomey et al. (1993) suggest that effective moisture decreased around 14,000 B.P. and then increased, peaking at ca. 10,500 B.P.

Collins (1995) divides the Paleoindian period into early and late subperiods. The early subperiod consists of two projectile point style intervals, Clovis and Folsom. Clovis chipped stone artifact assemblages, including the diagnostic fluted lanceolate Clovis point, were produced by bifacial, flake, and prismatic-blade techniques on high-quality and oftentimes exotic lithic materials (Collins 1990). Along with chipped stone artifacts, Clovis assemblages include engraved stones, bone and ivory 


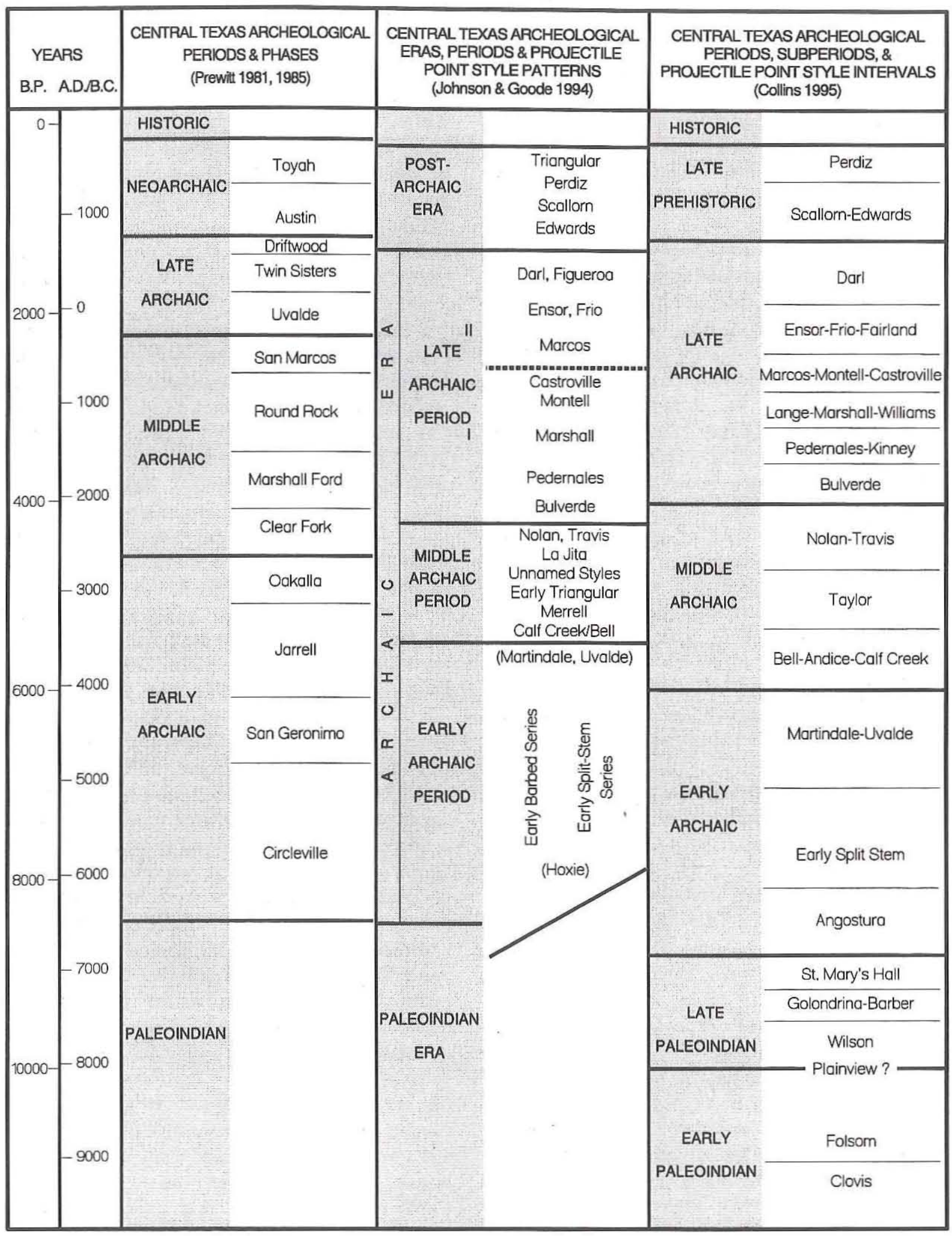

Figure 2. Comparison of prehistoric cultural sequences of Prewitt (1981:Figure 4, 1985:Figure 5), Johnson and Goode (1994:Figure 2), and Collins (1995:Table 2). 
points, stone bolas, and ochre (Collins 1995:381; Collins et al. 1992). Analyses of Clovis artifacts and site types suggest that Clovis "peoples" were well-adapted, generalized hunter-gatherers with the technology to hunt larger game but that they did not solely rely on it. In contrast, Folsom tool kits, consisting of fluted Folsom points, thin unfluted (Midland) points, large thin bifaces, and end scrapers, are more indicative of specialized hunting, particularly of bison (Collins 1995:382).

Spanning the end of the Early and initial Late Paleoindian subperiods are several projectile point styles for which temporal, technological, or cultural significance is unclear. Plainview, a type name typically assigned to any unfluted lanceolate Paleoindian point, is one example. Collins (1995:382) has noted that most of these points are not similar to the Plainview type-site points in thinness and flaking technology. Also problematic are the chronological position and cultural signifance of Dalton and San Patrice dart points. The succeeding Late Paleoindian subperiod includes three projectile point style intervals spanning the period from ca. 10,000 to 8800 B.P.: Wilson, Golondrina-Barber, and St. Mary's Hall. Components and artifact and feature assemblages of these three intervals appear to be Archaic-like in nature and in many ways may represent a transition between the Early Paleoindian and succeeding Archaic periods (Collins 1995:382).

The Archaic period ( 8800 to $1300-1200$ B.P.) is generally believed to represent a shift toward hunting and gathering of a wider array of animal and plant resources and a decrease in group mobility (Willey and Phillips 1958:107-108), although such changes may have been well under way by the beginning of the period. Throughout the ca. 7,600year-long period, major climatic changes probably presented Archaic populations with varying subsistence challenges. The Archaic is generally subdivided into Early, Middle, and Late subperiods (Black 1989; Collins 1995; Story 1985:28-29). Each of the three subperiods includes several temporal-stylistic units or intervals based on diagnostic projectile point styles and associated radiocarbon assays (Collins 1995).

Early Archaic (8800-6000 B.P.) sites are small and their tool assemblages are very diverse (Weir 1976:115-122), suggesting that populations were highly mobile and densities low (Prewitt 1985:217). It has been noted that Early Archaic sites are concentrated along the eastern and southern margins of the Edwards Plateau (Johnson and Goode 1994; McKinney 1981). This distribution may be indicative of climatic conditions at the time, as these environments have many more reliable water sources and a diverse subsistence base. Microfaunal records and sedimentary evidence from stream valleys and along the eastern Edwards Plateau depict a climatic regime in flux, from mesic conditions during the beginning of the Early Archaic to extremely xeric and back to mildly xeric conditions at the end of the subperiod (Collins et al. 1990; Toomey et al. 1993). Three projectile point style intervals are recognized: Angostura, Early Split Stem (including Gower and Jetta), and Martindale-Uvalde. Manos, metates, hammerstones, Clear Fork and Guadalupe bifaces, and a variety of other bifacial and unifacial tools are common to all three intervals. The construction and use of rock hearths and ovens reflect a specialized subsistence strategy (exploitation of roots and tubers?) during the Early Archaic. These burned rock features most likely represent the technological predecessors of the larger burned rock middens extensively used later in the Archaic period (Collins 1995:383).

During the Middle Archaic period (60004000 B.P.), the number and distribution of sites, as well as site size, increased, probably due to increases in population densities (Prewitt 1981:73; Weir 1976:124, 135). Macrobands may have formed at least seasonally, or an increased number of small groups may have utilized the same sites for longer periods of time (Weir 1976:130-131). A greater reliance on plant foods is suggested by the presence of burned rock middens toward the end of the Middle Archaic, although tool kits still imply a strong reliance on hunting (Prewitt 1985:222-226). Three projectile point style intervals constitute the Middle Archaic: Bell-Andice-Calf Creek, Taylor, and Nolan-Travis. The Bell-Andice-Calf Creek and Taylor intervals reflect a shift in lithic technology from the preceding Martindale-Uvalde interval (Collins 1995:384).

Johnson and Goode (1994:25) suggest that the Bell-Andice-Calf Creek interval represents an influx of bison-hunting groups from the Eastern Woodland margins into the Central Texas region during a slightly more mesic period. Bison disappeared as more-xeric conditions returned during the later Nolan-Travis interval. The style change represents another shift in lithic technology (Collins 1995:384; Johnson and Goode 1994:27). Prewitt (personal 
(1995:386) divides this period into three subperiods. The first subperiod, beginning in the late seventeenth and early eighteenth centuries, marks an era of more-permanent contact between Europeans and Native Americans as the Spanish moved northward out of Mexico to establish settlements and missions on their northern frontier. There is little available information on aboriginal groups and their ways of life except for the fragmentary data gathered by the Spanish missionaries. Much of this fragmentary data comes from the San Antonio and South Texas areas. Groups in these areas have been collectively referred to as Coahuiltecans because of an assumed similar way of life; however, many individual groups existed (Campbell 1988). The inevitable and disastrous impacts to native social structures and economic systems by disease and hostile encounters with Europeans and intruding groups, such as the Apache, were already underway at this time.

The second subperiod begins with the establishment of the mission system in the 1720 s and ends with its ultimate demise around 1800 . Some indigenous groups moved peacefully into mission life, giving up their nomadic hunting and gathering way of life. Others were forced in or moved in to escape the increasingly hostile actions of southwardmoving Apaches and Comanches. By the end of this time, many Native American groups had been decimated by European expansion and disease; intrusive groups such as the Tonkawa, Apache, and Comanche had moved into the region to fill the void. Few sites attributable to these groups, outside of mission sites, have been investigated. To complicate matters, many aboriginal ways of life continued even after contact with the Spanish. For example, the manufacture of stone tools continued for many groups even after settling in the missions (Fox 1979). The third subperiod, from 1800 to the last half of the nineteenth century, witnessed the final decimation of the aboriginal groups and the defeat and removal of the Apaches and Comanches to reservations by the United States.

\section{Previous Archeological Investigations in the Upper Brushy Creek Drainage Basin}

The earliest archeological investigations in the upper Brushy Creek drainage basin are credited to J. E. Pearce (1919, 1928-1938). Beginning around 1912 and continuing for almost 30 years, Pearce conducted a series of site reconnaissance efforts and excavations of burned rock middens. A few of his more notable burned rock midden excavations include the Cedar Park Mound (41WM8), the Cluck Springs Mound (41WM24), and the W. G. Bell Mound (41WM14).

Archeological investigations during the middle part of the century were limited, until recent development within the upper Brushy Creek watershed fostered several systematic archeological surveys and excavations. Whitsett (1981) and Fox and Whitsett (1984) conducted surveys along South Brushy Creek below the confluence of Cluck and Buttercup Creeks. The earlier survey documented site 41WM439, consisting of two burned rock middens and a dense scatter of lithic debitage at the confluence of Cluck and Buttercup Creeks. The later survey recorded 14 prehistoric sites along South Brushy Creek, including 1 rockshelter, 1 burned rock midden, 2 sites with burned rock middens associated with lithic scatters, and 10 lithic scatters (one is 41WM452, which extends into the current project area). Recommendations were made to either test or protect three sites thought to be significant (Fox and Whitsett 1984).

In the headwaters of Buttercup and Cluck Creeks, archeological surveys (Briggs 1983; Mercado-Allinger et al. 1984) recorded 10 prehistoric sites, including 1 upland burned rock midden, 3 lithic scatters associated with sinkholes, and 6 lithic scatters. Subsequent archeological testing by Coffman and Prewitt (1985) at two of the sinkhole sites (41WM572 and 41WM580) failed to demonstrate significance and eligibility for listing in the National Register of Historic Places.

The Texas Department of Transportation documented three prehistoric sites along Brushy and Spanish Oak Creeks during an archeological survey for the extension of FM 1431. Excavations were conducted at one of these sites, Wilson-Leonard (41WM235), in 1982-1984. Additional excavations at the Wilson-Leonard site were conducted by the Texas Archeological Research Laboratory (TARL), The University of Texas at Austin in 1992. The multidisciplinary investigations by TARL have provided significant data regarding paleoenvironments, human adaptations, and cultural chronology of Central Texas, particularly for the Paleoindian period (Masson and Collins 1995).

Several other archeological surveys have been conducted in the upper Brushy Creek watershed 
since the mid 1980s (Bryant 1985; Coffman et al. 1985; Fields et al. 1985; Howard 1983; Howard and Jackson 1984a, 1984b; Hubbard et al. 1984; Mercado-Allinger and Ragsdale 1984; Voellinger and Nightengale 1985). These surveys have documented over 80 prehistoric sites, primarily deflated upland lithic scatters and burned rock middens. Many of these sites are disturbed or have little contextual integrity due to erosion, overgrazing, land-clearing activities, and development. Few if any of the sites were recommended as eligible for listing on the National Register of Historic Places.

\section{Historical Overview}

\section{The Samuel Damon and Rachel Saul Surveys before 1942}

The project area encompasses portions of the Rachel Saul and Samuel Damon Surveys, two large nineteenth-century grants that lay along the waters of South Brushy and Cluck Creeks (Figures 3 and 4). Settlement adjacent to the project area occurred by the 1830 s but appears to have been delayed in the area itself until the turn of the century.

Prior to 1900, ownership of a portion of the Saul League was vested in speculator Morgan C. Hamilton, who subdivided his holdings into 14 lots of varying sizes shortly before completion of the Austin and Northwestern Railroad and development of Rutledge, a community and trade center (Deed Record 27:405-407; ${ }^{1}$ Scarbrough 1980:450). Sales of the lots were slow, and the portion of the Saul Survey located in the eastern half of the project area remained vested in Hamilton, his nephew Robert A. Smith, and Travis County resident N. B. Mays until the mid 1880s (Deed Record 34:130-131; 39:40-41).

Intensive agricultural and natural resources development of the project area is believed to have occurred by the turn of the century, when approximately 1,500 acres in the Saul and Damon Leagues were owned by W. E. Armstrong of Travis County and John Tyler of Williamson County (Deed Record 112:373-377). In 1904, Tyler became the sole owner of the acreage (Deed Record 113:373-377), and he appears to have been the first individual to develop the property intensively. Encouraged by the County. proximity of the railroad, which was being used by numerous capitalists to transport cedar products from the Hill Country, Tyler deeded the timber on much of his property to A. F. Martin \& Brother, an Austin firm that dealt in cedar (Deed Record 113: 598-600). Between 1905 and 1908, the Martins held a lease that allowed them to establish work camps (site 41WM892) and cut timber on 731 acres in and adjacent to the project area and to ship cordwood out from Rutledge Station on the Houston and Texas Central Railroad.

On October 14, 1912, John Tyler sold eight tracts of land in the Saul and Damon Surveys to J. T. and W. B. Sites of Caldwell County; less than 2 years later, W. B. Sites sold his half-interest to J. T. Sites, who had become a resident of Williamson County (Deed Record 161:293-296, 400-402). Sites then held the tracts intact until 1916, when he sold the 467 acres in the Saul Survey (lots 9 and 12-14; and all of lots 5,10 , and 11 lying west of the Houston and Texas Central right-of-way) to R. L. Bewley (Deed Record 177:106-107). The Bewleys owned the land only briefly before selling it to Austin druggist Van M. Smith (Austin American, July 27, 1959:3, July 28, 1959:23; Austin Statesman, July 27, 1959:7; Deed Record 181:28-29). One-anda-half years later, O. L. Koock bought the land (Deed Record 183:604-606), which became known as the Koock Ranch. While the Koocks probably constructed extensive improvements in the western portion of lot 10 (now demolished), their residence was in Austin, 'where Koock owned a hardware store and jewelry company on Congress Avenue (American Statesman, October 4, 1940:n.p.).

In 1935, Koock lost his Williamson County property to foreclosure by the Montpelier Savings Bank and Trust Company of Montpelier, Vermont (Deed Record 276:115). The company held the eastern portion of the Koock Ranch intact until March 29, 1937, when it sold 128 acres to the Lower Colorado River Authority (Deed Record 283:549). Eight months later, the company sold the balance of the land west of the railroad right-of-way to Hays County residents T. W. and Hattie Rhodes (Deed Record 288:459). Soon after, the Rhodeses moved to their 339-acre tract, where they operated a stock farm until 1945 (Williamson County Sun, April 28, 1966:2). They were joined by their son, E. D. (Dean) Rhodes, who lived in Austin but who bought the 113.85-acre tract immediately south of the T. W. Rhodes farm from the Lower Colorado 


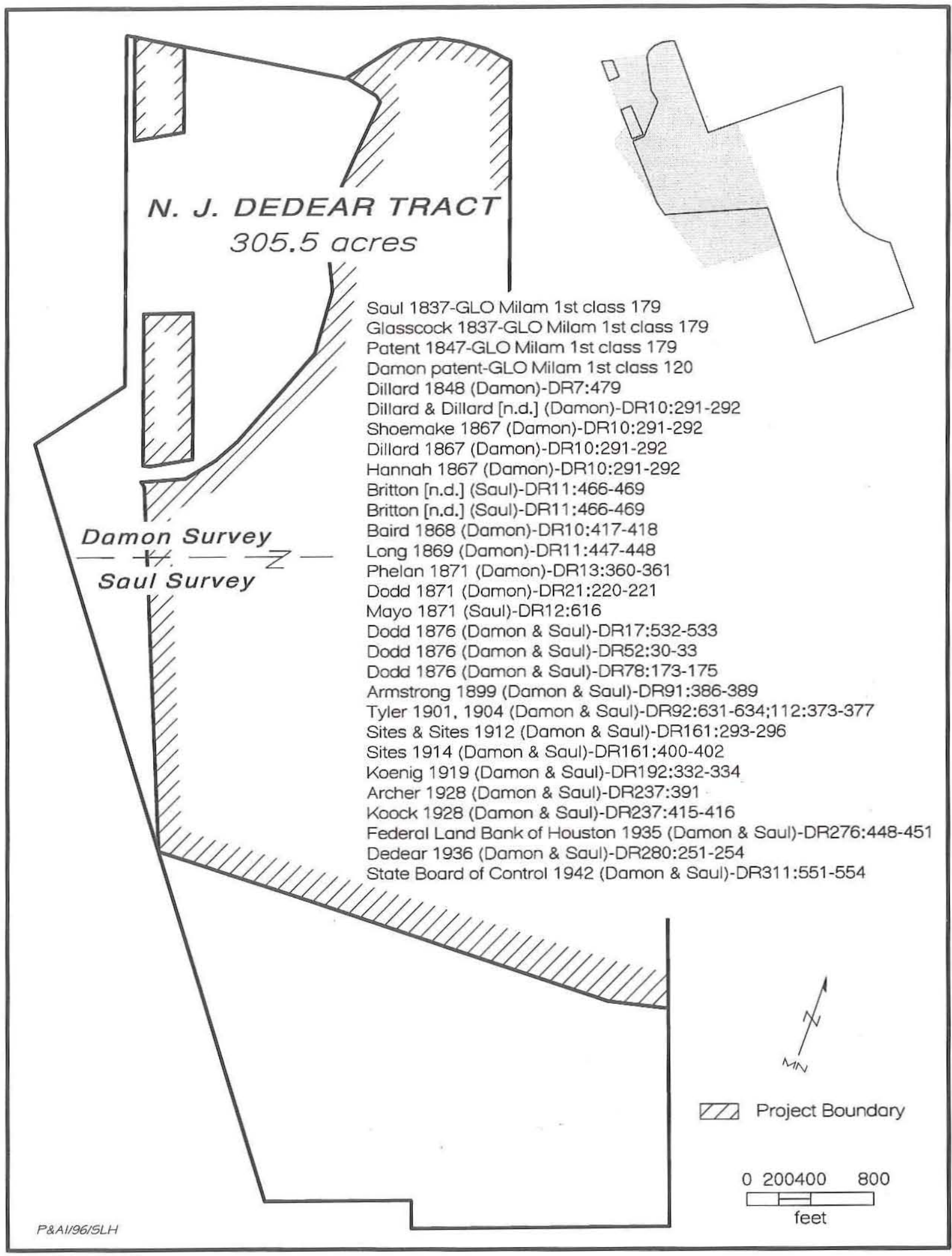

Figure 3. Property transactions involving the N. J. Dedear tract, 1837-1942. 
Saul 1837-GLO Milam 1st class 179

Glassock 1837-GLO Milam 1st class 179

Patent 1847-GLO Milam 1st class 179

Hamilton 1854-DR31:159-160

Mays 1881 (lots 11-12)-DR39:40-41

Smith 1883 (lots $3,5,6,9,10,13,14$ )-DR31:159-160

Graves 1884 (lots 3, 5, 6, 9-14)-DR34:130-131; 39:40-41

Graves 1894 (lots 3-6, 9, 10, 13, 14)-DR77:42-43

Green (lots 5, 11, 12)-DR73:180-181

Graves 1898 (lots 9, 10, 13, 14)-DR87:200-201

Purcell 1900 (lots 10, 13)-DR90:139

Armstrong \& Tyler 1904 (lots 5, 11, 12)-DR111:339-342

Tyler 1904 (lots 5, 9-14)-DR112:373-377

Sites \& Sites 1912 (lots 5, 9-14)-DR161:293-296

Sites 1914 (lots 5, 9-14)-DR161:400-402

Bewley 1916 (lots 5, 9-14)-DR177:106-107

Smith 1916 (lots 5, 9-14)-DR181:28-29

Koock 1918 (lots 5, 9-14)-DR183:604-606

Koock 1918 (lot 9)-DR185:553-554

Montpelier Savings Bank \& Trust Co. 1935 (lots 5, 9-14)-DR276:115

T. W. Rhodes 1937 (339 ac.)-DR288:459

/ State Board of Control 1945 (339 ac.)-DR328:548-549
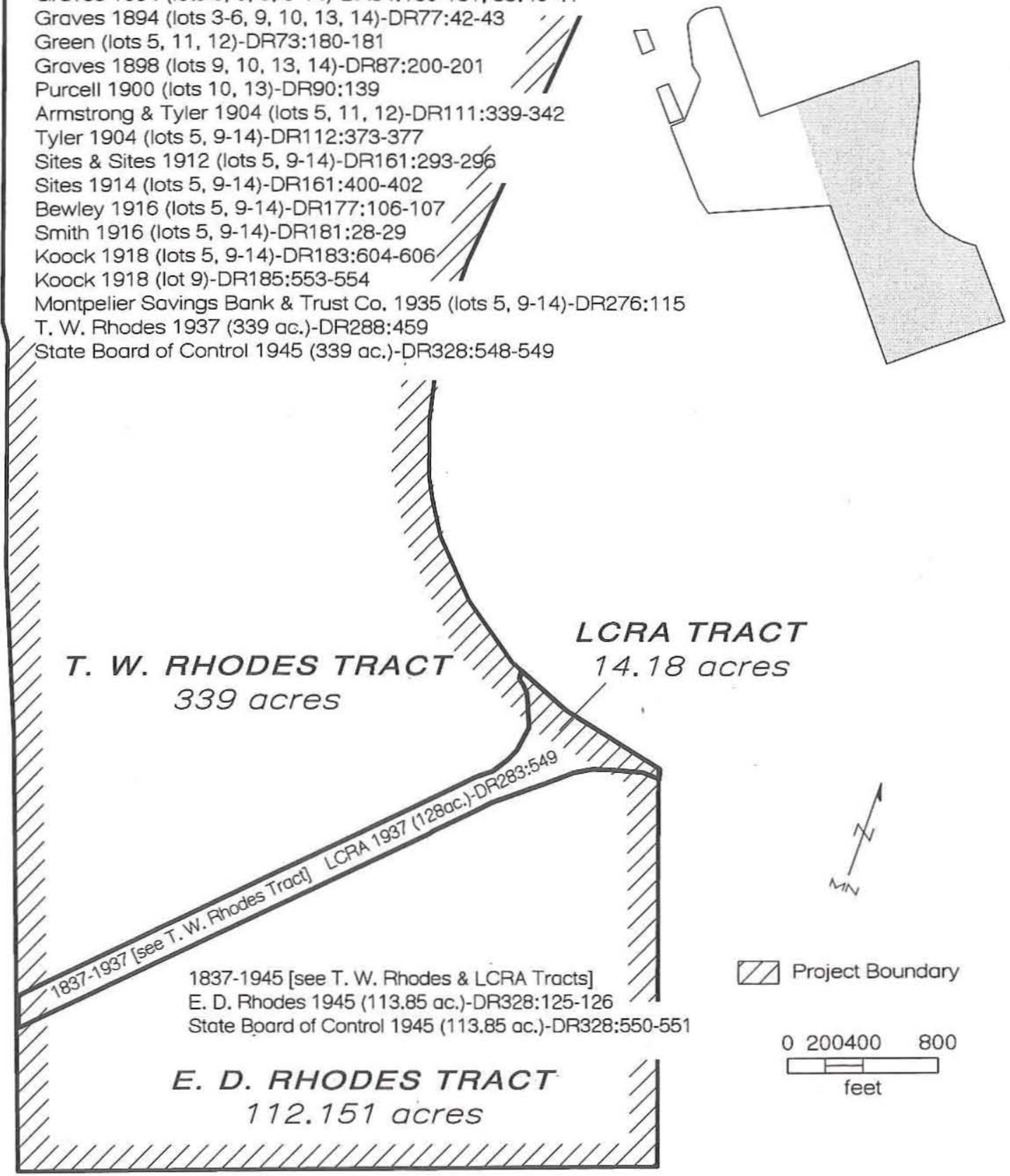

P\&AI/96/SLH

Figure 4. Property transactions involving the T. W. Rhodes, E. D. Rhodes, and LCRA tracts, 1837-1945. 
River Authority on April 12, 1945 (Deed Record 328:125-126). Later that year, the two families sold their farm tracts to the State Board of Control, and the land passed from private ownership (Deed Record 328:548-551).

West of the Rhodes farms on the Rachel Saul and Samuel Damon Surveys, J. T. Sites retained ca. 441 acres after selling off the land to the east to R. L. Bewley in 1916. On December 22, 1919, he sold the balance of his property to Paul Koenig of Williamson County (Deed Record 192:332-334). The Koenigs held the land until April 27, 1928, when they conveyed 325 acres to Austin resident Roy C. Archer (Deed Record 237:391). On October 6, 1928, Archer sold ca. 305 acres of the property to O. L. Koock, who added that acreage to his ranch to the east in the Saul Survey (Deed Record 237: 415-416) and subsequently lost it in foreclosure to the Federal Land Bank of Houston (Deed Record 276:448-451).

On May 29, 1936, the land in the project area was divided once again when the Federal Land Bank sold the western portion of the Koock Ranch to N. J. Dedear of Williamson County (Deed Record 280:251-254). Comprised of 307.05 acres in the Saul and Damon Surveys, the new Dedear tract encompassed the western portion of the survey area. It was the location of a farmstead (now destroyed) which the Dedears repaired or rebuilt in 1937 (Deed of Trust Record 66:216).

The Dedear family ranched on their property from 1936 until 1942, when they sold 305.05 acres in four tracts to the State Board of Control (Deed Record 311:511-554). N. J. and Ellen Dedear moved to Round Rock, and the state began to use the property for agricultural purposes within a year.

\section{Planning, Acquisition, and Development of the State Dairy and Hog Farm}

Acquisition of land for a state dairy and hog farm did not occur until June 1942. However, the State Board of Control had become increasingly aware after December 1941 that purchase of a facility where it could raise dairy cows and swine, use garbage generated by Austin's eleemosynary (charitable) institutions, and contribute to their relative self-sufficiency in the production of meat and milk was a problem to be solved. Three issues in particular made acquisition and development of such a facility desirable. First, while eleemosynary institutions in Texas had a long tradition of supplying their own needs through farming and gardening (Foster 1889:xxxii), nonetheless they also relied on private companies to supplement meat, fruit, and other foodstuffs. After 1941, however, meat, milk, fruits, and vegetables became scarce as supplies were diverted to the government in support of the war effort. Second, as the government became increasingly restrictive, there was a threat that slaughter facilities at the abattoir in Austin might not be available to the state. In 1943, the federal Office of Price Administration ordered city abattoirs closed and filed suit against the City of Austin (State Board of Control, Box 1991/16-53). Unfortunately, as the local newspaper pointed out, "the bureaucracy" failed to appreciate the fact that the state had been unable to get bids on the meat required for its wards, and so the Board of Control had been forced to buy live animals and have them slaughtered locally. The Austin abattoir was the only place where that activity could be carried out safely. Closure of the facility "would send the state back to the primitive procedure of butchering its meat out under the trees," wasting food desperately needed by the state hospitals and homes (Austin History Center, AF, Municipal Buildings). Finally, the state needed additional facilities in which to house numerous syphilitics. According to Wynn (1996), "the state jails were crammed full" of these individuals, and "the county commissioners and judges were eating [the State Board of Control] up," demanding that the Board take care of the problem. The Austin State Hospital had to make room for these men, but there was no space at the hospital. In desperation, the Board's new chairman, Weaver Baker, sent approximately 100 patients to the Steiner Ranch west of Austin where they lived in a tent camp and cut cedar. Later, the same group was sent to the old Civilian Conservation Corps camp at Longhorn Cavern. In the 1940s, the State Dairy and Hog Farm provided room for as many as 50 patients from the State Hospital. The men lived at the farm in a dormitory and worked with the animals (Wynn 1996).

In early 1942, when the State Board of Control began its search for a rural tract, board members and the legislature had several specific aims in mind. According to State Auditor C. H. Cavness (American Statesman, February 20, 1948:n.p.), the state did not intend that the new facility would be self-sustaining. Rather, it would "furnish a use for garbage from the 
local institutions, remove the menace to public health caused by raising hogs within the city limits of Austin, and provide a place for combining dairy and swine raising activities - thereby reducing [the] cost of operating such enterprises separately at each institution." Finally, the "farm" would provide "work of considerable therapeutic value to a limited number of patients and[,] in addition, [augment] the supply of much needed raw milk for processing by the Austin State Hospital dairy products plant for use in the various institutions" (State Board of Control, Box 1991/16-56). In Austin, similar therapeutic systems were in place at the Austin State School Farm Colony east of town and the Austin State Hospital, where patients helped to raise crops and were "employed for occupational therapy treatment" (Cavness [1948]:14).

By March of 1942, the Board's Superintendent of Dairies, A. T. Bratton, had examined scores of tracts, rating them according to their size, price, distance from Austin, improvements, and availability to water (State Board of Control, Box 1991/16-9). Some lobbying was done by agents for prospective sellers (State Board of Control, Box 1991/16-53), but on April 15, 1942, the State Board of Control voted to purchase the Dedear farm "for the use of dairy and hog ranch. ..." The price was $\$ 27.50$ per acre. According to meeting minutes, the farm was 14 miles northwest of the Austin State Hospital and consisted of 305 acres, 20 of which were in cultivation. While cedar was present, approximately 150 acres of pasture had been cleared. Livestock on the farm included 60 sheep, 50 goats, 15 head of cattle, and 4 horses. Improvements, which were located in the vicinity of the future dairy and hog farm headquarters, consisted of a recently rebuilt six-room frame house with a sheet iron roof, a 20 -x-65-ft sheep shed, a small grain bin, a $247-\mathrm{ft}-$ deep water well with windmill, and a surface tank that had been created when a dam was built across the nearby creek (State Board of Control, Box 1991/16-9).

The State Board of Control officially established the State Dairy and Hog Farm in June 1942, and by September, future farm superintendent Charles Goodwin was living at the facility, probably in the old Dedear home (State Board of Control, Box 1991/16-44). While operations at the farm appear to have been minimal during the balance of 1942 , the Board clearly was making plans for physical improvements. In July 1943, for example, they requested proposals to "cut all cedar timber located on an area of the Dedear Farm in Williamson County, Texas, to be designated by C. A. Goodwin, Superintendent . . ." (State Board of Control, Box 1991/16-44). They also prepared a budget that would provide funding for buildings that would be used by the dozen-odd employees and approximately 16 patients from the Austin State Hospital who worked at the facility (State Board of Control, Box 1991/16-56).

The fiscal year August 31, 1943-August 31, 1944 , was a busy one that resulted in the construction of buildings and infrastructure and in the creation of the basic spatial organization of the facility (Figure 5). In general, the northern portion of the Dedear tract was used for the swine operation and included hog pens and farrowing sheds. The central portion of the tract included the dairy operation, housing, administrative facilities, and basic infrastructure (Wynn 1996). An accounting of monies expended at the facility indicates that a number of buildings were erected, including three brick cottages for employees $(\$ 8,960.00)$, a kitchen and dining room for patients $(\$ 3,970.00)$, and sleeping quarters for patients $(\$ 5,975.00)$. Improvements to the infrastructure included repairs to the tank dam and completion of a water system $(\$ 9,000.00)$, installation of a sewage disposal system $(\$ 6,980.00)$, installation and extension of electric services $(\$ 1,490.00)$, road construction $(\$ 1,975.00)$, and fences and fence improvement $(\$ 1,980.00)$ (State Board of Control [1947]:57-58).

State Board of Control records show that farm production stood at $\$ 17,604.50$, income derived largely from the sale of milk and hogs. That amount compared favorably with 1942-1943 gross production values for the other two state institutions in Austin that showed farm income. The Austin State Hospital, for example, had income of $\$ 4,717.50$, while the Austin State School Farm Colony had income of $\$ 17,089.15$ (State Board of Control, Box 1991/16-84). According to a Board press release, the total value of all agricultural and dairy goods produced by the state's 23 eleemosynary institutions during the year preceding the State Dairy and Hog Farm's first full year of production was $\$ 645,885.56$, almost half of that coming from dairy products and $\$ 72,454.21$ being derived from hogs (State Board of Control, Boxes 1991/16-40 and 1991/16-84).

The outstanding first year of production at the 
Figure 5. Historic properties at the State Dairy and Hog Farm, 1945. 
State Dairy and Hog Farm was followed in 19441945 by larger production statistics as the facility leased adjoining farmland and continued to improve its buildings and infrastructure. ${ }^{2}$ No doubt concerned by the federal government's threat to close the Austin abattoir, the Board of Control apparently authorized construction of a slaughterhouse at the State Dairy and Hog Farm near the hog pens in the northern portion of the Dedear tract. Board records indicate such a structure was in place by 1944-1945 (State Board of Control, Box 1991/16-44). ${ }^{3}$ Production increased, and by September 1, 1945, the superintendent could report that the farm had provided 496,196 pounds of raw milk, 515 hogs, and 50 calves to the system (State Board of Control, Box 1991/16-44).

At the beginning of the state's development of the State Dairy and Hog Farm, the Board of Control had hired an Austin architect named Walter C. Moore, Jr., to provide engineering and design services. A graduate of Austin High School and The University of Texas with a bachelor of science degree in architecture, Moore began work for the Board by at least early 1943, when he was involved in the design and construction of not only buildings at the farm but also the design and construction supervision of improvements at the Texas Confederate Home for Men (State Board of Control, Box 1991/16-65). He was employed first in the Engineering Division (State Board of Control, Box 1991/16-12), where he became the Board's sole architect after several other men entered military service (State Board of Control, Box 1991/16-65). In October 1945, he officially was appointed to act as architect for the Board of Control "to perform all the duties now assigned him, as well as for the further purpose of designing for eleemosynary service new buildings provided for from current

\footnotetext{
${ }^{2}$ While published biennial appropriation budgets do not show that any funds were expended for construction in 1944-1945, a note in the accounts generated by the State Dairy and Hog Farm indicates that out of an appropriation of $\$ 37,980.00, \$ 20,755.07$ was spent on new construction (State Board of Control, Box 1991/16-44).

${ }^{3}$ According to a communication from the Board chairman to Mayor Tom Miller, the Board had to supply some 9,000 pounds of dressed meat every week to the eight state institutions that were located in and adjacent to Austin (State Board of Control, Box 1991/16-53).
}

appropriations, and for the further purpose of planning reconversion of army camps, or posts already assigned us, or which may hereafter be assigned. . ." (State Board of Control, Box 1991/16-12). Moore worked as the Board's architect from 1945 to 1949 and then as supervising architect for the Board of Texas State Hospitals and Special Schools from 1949 until 1957, when he joined The University of Texas system (Austin American-Statesman, August 29, 1984:F24).

By 1945, when the State Dairy and Hog Farm was operating at capacity, the State Board of Control began to contemplate acquisition of two adjoining tracts of land in order to establish "a school for delinquent negro girls." The Board purchased 452.85 acres adjoining the current facility from T. W. and Hattie Rhodes and E. D. (Dean) and Fern Rhodes for a total of $\$ 17,208.30$ on August 27, 1945 (Board of Control, Box 1991/16-12; Deed Record 328:548-551). Almost immediately, however, a World War II prisoner of war camp in Mexia became available, and the State Board of Control decided to convert that facility instead for use by the school. As a result, the Rhodes tracts became available for use by the State Dairy and Hog Farm, the capacity of which more than doubled. In September 1945, the Board ordered that World War II veteran Leonard Wynn be appointed manager of the "Rhodes farm." He and his wife moved into the Rhodes farmstead, which consisted of a residence, smokehouses, a barn, crib, garage, brooder house, and several sheds (State Board of Control, Box 1991/16-85).

Under the leadership of Moore and the State Board of Control, the State Dairy and Hog Farm changed and developed significantly during the postwar years (Figure 6). Within 2 weeks of his appointment, for example, Moore recommended reusing a number of the hundreds of governmentconstructed buildings that had been declared surplus. Among the buildings located at the Longhorn Cavern Civilian Conservation Corps Camp that the Board approved moving to the farm were 15 units of prefabricated shed-type garages that could be dismantled and reassembled to provide two $24-\mathrm{x}-90-\mathrm{ft}$ cow sheds. Another prefabricated building measuring $20 \times 70 \mathrm{ft}$ could be moved and re-erected "to serve as a kitchen and dining hall for negro and white patients and white employees." Finally, Moore recommended that the kitchen and dining hall spaces in the current farm dormitory be converted 
Figure 6. Historic properties at the State Dairy and Hog Farm, 1950. 
into additional dormitory space and that J. A. Wallace be employed as carpenter-foreman to carry out the re-erection and conversion work (State Board of Control, Boxes 1991/16-12 and 1991/16-18).

During the winter of 1945-1946, Moore also oversaw the design and construction of new buildings at the State Dairy and Hog Farm. According to a general repairs and improvements appropriation dated February 1, 1946, preliminary plans were being prepared for new slaughterhouse equipment, and money had been budgeted for four other items: (1) installation of a cold storage plant for cooling and curing needs; (2) purchase of hog slaughtering and processing equipment; (3) construction of additional hog sheds, feeding platforms, and fencing; and (4) acquisition of dairy barn equipment. The total cost of these improvements was $\$ 21,500.00$ (State Board of Control, Box 1991/16-31).

Follow-up inspection reports dated February 18 and March 22, 1946, indicate that facilities on-site included a dormitory, milking barn, sewage disposal plant, storage warehouse, three brick cottages, a slaughterhouse, and barns and sheds (State Board of Control, Box 1991/16-31). Four months later, inspection reports noted the presence of a dormitory building where renovations had occurred, a milking barn, four cow sheds, a feed barn, a small salt house, three brick cottages, a small garage, a slaughterhouse, and a small cottage at the hog pens. The reports also confirmed the completion of the new kitchen and dining room building which was built with materials salvaged from the Longhorn Cavern Civilian Conservation Corps Camp (State Board of Control, Boxes 1991/16-32, 1991/16-56, and 1991/16-65).

Improvements to buildings at the State Dairy and Hog Farm were paralleled by improvements to the grounds. August 1946 saw the removal of underbrush and small timber to increase pasture size and grass cover, as well as the transporting of patients to cut cedar posts and repair and rebuild outside fence lines (State Board of Control, Boxes 1991/16-31 and 1991/16-32). One observer also remarked on the need to improve the slaughter equipment and hog pens on the Dedear tract: the pens were in "unbelievable" condition, and he was astounded that "we could be raising so many hogs under such unsanitary conditions (even for hogs). The slaughter equipment, of which there is practically nothing, is entirely inadequate for serving almost all of the Austin institutional population."
He suggested that the Board of Control make use of the appropriation that had been made for slaughtering, and that they "make provision for the removal of all hog pens to an area which is more easily drained and where the hogs can get to some green pasture" (State Board of Control, Box 1991/16-56).

Improvements and additions continued in 1947 with the hauling of gravel from a pit near the slaughterhouse to cover roads and dairy and hog lots. Superintendent Goodwin, with Moore's recommendation, hired James A. Wallace as carpenter foreman in March 1947 "to construct two new buildings" at the farm (State Board of Control, Box 1991/16-31). One of those buildings was a duplex cottage that was completed in the fall of 1947 and was located near the three brick cottages. The location of the second building is not known (State Board of Control, Box 1991/16-31).

In February 1948, Business Manager Leonard L. Wynn was able to report that, on a monthly average, the State Dairy and Hog Farm furnished approximately 15,000 pounds of pork and about 50,000 to 60,000 pounds of raw milk to the Austin State Hospital Dairy Products Plant. ${ }^{4}$ The farm had as a goal the furnishing of enough pork to satisfy the needs of all the eleemosynary institutions in Austin. Construction and improvement of the existing plant was helpful in achieving this goal, as was the constant brush clearing to open new pastures. But what was needed above all else was construction of new hog pens. Wynn projected that such pens would allow the farm to "almost double our hog production with hardly any new added operating expense" (State Board of Control, Box 1991/16-56).

An inventory of the State Dairy and Hog Farm on August 31,1948, revealed that the farm was an intensively developed facility (Table 1). The following buildings were located at the Dedear property (adjacent to present-day U.S. Highway 183): the storekeeper-accountant's office and warehouse, a carpenter shop, dormitory, and main kitchen and dining room. Four cottages provided housing for the superintendent, storekeeper-accountant, head dairyman, and head farmer. In addition, there were two duplex cottages. The dairy area included a dairy barn, three feed storage barns, a salt house,

\footnotetext{
${ }^{4}$ This plant was located near the intersection of Guadalupe Street and Lamar Boulevard.
} 
and four holding pen sheds. Miscellaneous buildings included two garages, a storage shed, two chicken houses, and a slaughterhouse. Finally, the Dedear portion of the farm also included old hog pens, a pump house, barn, 48 farrowing sheds, sheds for shelter, and group sheds.

To the east, at the Rhodes portion of the farm, were 40 new farrowing sheds. Southeast of the new sheds, the Rhodes farm buildings still were intact. It seems likely that the Rhodes residence was occupied by an employee who oversaw the hog operation, since the head dairyman and farmer had accommodations at the headquarters on the old Dedear farm (State Board of Control, Box 1991/16-85).

Appropriation budgets for the years 1949-1953 were nonspecific beyond indications of expenditures for "improvements and repairs." None of those budgets indicates that funds were spent for new facilities at the State Dairy and Hog Farm. In addition, annual reports of the Board of Control to the governor are missing for the critical years 1954-1957. However, information provided by former storekeeper-accountant Leonard Wynn indicates that the period 1949-1951 represented a watershed for the farm. First, a legislative act split up the eleemosynary system in 1949 and created the Board of Texas State Hospitals and Special Schools. Subsequently, the Board hired Dr. T. B. Carroll to serve as veterinarian. According to Wynn (1996), Carroll "cleaned things up," purchased improved Holsteins in Minnesota, and doubled the farm's milk production.

Carroll's employment was followed by the resignation of superintendent Charles Goodwin, who was replaced by Leonard Wynn. Wynn phased out the dairy operation and doubled the size of the hog operation, completing construction of the easternmost facilities on which construction had begun in the late 1940s. He also promoted and encouraged the involvement of resident patients at the farm, recognizing the therapeutic value of outdoor work as the men began to take on simple and then more complicated tasks (Wynn 1996). ${ }^{5}$

\footnotetext{
${ }^{5}$ Wynn (1996) credited the ideas of psychiatrist Karl Menninger, a native of Topeka, Kansas, who was trained as a doctor at Harvard University and, with his father and brother, established an important clinic in Topeka. Eventually, Menninger became chief consultant to the
}

Further expansion of the hog operation occurred in the mid 1950s, when Wynn oversaw construction of another 52 farrowing sheds and 7 group sheds located west of the first set of sheds built in 1950 (Figure 7). With his staff, Wynn also fine-tuned the farm operation, introducing an innovative system for feeding the hogs that used a truck, garbage collected at each of the state institutions in Austin, and steam that cooked the garbage before it was fed to the hogs. By the 1960s, this highly successful system was one of the most productive in the state, and farm workers raised and slaughtered approximately 3,000 hybrid hogs per year.

Operation of the State Dairy and Hog Farm continued even as control of the farm was transferred to the newly created Texas Department of Mental Health and Mental Retardation in 1965 (Department of Mental Health and Mental Retardation, Leander Rehabilitation Center-History). In May 1969, the last of the hogs were slaughtered at the farm. Simultaneously, the 61st Legislature authorized the Department of Mental Health and Mental Retardation "to construct, establish and maintain a special facility for the resocialization, training, education, rehabilitation, supervision, treatment, care and control of mentally ill and mentally retarded persons of this state" (Department of Mental Health and Mental Retardation, Leander Rehabilitation Center-History). During the next decade, the Department of Mental Health and Mental Retardation redeveloped the site (now called the Leander Rehabilitation Center), removing some buildings that had been used in the operation of the farm, modifying others to serve as recreational and treatment facilities, and building new facilities such as camp houses and a dam across South Brushy Creek to create a lake (Department of Mental Health and Mental Retardation, Ownership Records).

Between ca. 1969 and 1985, Department of Mental Health and Mental Retardation patients enjoyed the relatively secluded facilities at the Leander Rehabilitation Center. Then in 1985 the legislature passed SB 1350, by which the General Land Office conveyed 50 acres in the northwest corner of the center to the Texas Parks and Wildlife

Kansas state hospitals, an advocate for the mentally ill in state institutions, and a promoter of the important roles hospital personnel could play in the healing of patients (Hall 1959:xvi-xxvi). 
TABLE 1

STATE DAIRY AND HOG FARM INVENTORY, AUGUST 31, 1948*

\section{Land and Improvements}

Land:

Dedear Farm, 305.50 Acres

Rhodes Farm, 452.15 Acres

Total Land

Improvements:

Roads

Fences, Gates and Cattle Guards

Water Wells, Mains, Towers, Sewer Lines, etc.

Miscellaneous Improvements

Dairy Barn

Old Hog Pens

Total Improvements

\$ $19,986.27$

$17,211.95$

$37,197.32$

$8,238.64$

$5,644.67$

$12,523.36$

900.15

859.92

$28,166.74$

Total Land and Improvements

$65,364.06$

\section{Buildings}

Administration:

Storekeeper-Accountants Office and Warehouse

Carpenter Shop

Dormitory

Main Kitchen and Dining Room

Dairy:

Dairy Barn

Feed Storage Barn - A

$$
\begin{aligned}
& -B \\
& -C
\end{aligned}
$$

$8,000.00$

800.00

$8,000.00$

$2,000.00$

$10,000.00$

$2,000.00$

$2,000.00$

$2,000.00$

100.00

Salt House

Holding Pen Shed - A

$$
\text { - B }
$$

- C

- D

$1,000.00$

$1,000.00$

$1,000.00$

$1,000.00$

Miscellaneous:

Garage, Superintendent's Residence

Storage Shed for Residences

Chicken Houses, Frame - 2 @ \$25.00

500.00

500.00

50.00

500.00

Garage, Truck and Tractor

$1,500.00$

New Hog Pens, Rhodes Farm:

Tool House and Utility Shed

200.00

Sheds, Farrowing - 40@\$200.00

$8,000.00$

Old Hog Pens, Dedear Farm:

Pump House

Feed Storage Barn

Sheds, Farrowing - 48 @ \$83.33

100.00

$1,000.00$

$4,000.00$

100.00

$3,000.00$

Sheds, Group -6 @ \$500.00

Picnic Grounds:

Cook Shack, Sheet Iron

200.00

Outdoor Toilet

50.00 


\begin{tabular}{|l|r|}
\hline Table I, continued & \\
\hline Residence Houses: & $5,000.00$ \\
Superintendent's Home & $4,000.00$ \\
Storekeeper-Accountants Cottage & $4,000.00$ \\
Head Dairyman's Cottage & $2,000.00$ \\
Head Farmer's Cottage & $5,000.00$ \\
New Duplex Cottage & $4,000.00$ \\
Old Duplex Cottage & $4,000.00$ \\
Rhodes Farm Buildings: & 50.00 \\
Residence & 10.00 \\
Brooder House, Chickens & 25.00 \\
Outdoor Toilet & 25.00 \\
Chicken House, Pole Frame & 50.00 \\
Smoke House, Log & 500.00 \\
Smoke House, Railroad Ties & 75.00 \\
Barn, Feed - Log & 75.00 \\
Sheep and Goat Shed & 50.00 \\
Cow Shed, Milking & $1,100.00$ \\
Crib, Grain and Hay, Log & \\
Garage, Truck and Tractor & $88,560.00$ \\
Total Buildings & \\
\hline *Fom State Board of Control, Box 1991/16-85. & \\
\hline
\end{tabular}

Department. Three years later, SB 52 passed by the 70th Legislature transferred the balance of the tract to the State Department of Highways and Public Transportation (now TxDOT). The Department of Mental Health and Mental Retardation leased the facilities back for 5 years, but the Leander Rehabilitation Center finally closed on August 31, 1993 (Department of Mental Health and Mental Retardation, Leases, Permits and Licenses).

\section{Conclusions}

Agricultural and commercial development of the project area appears to have occurred in the late nineteenth century, spurred initially by construction of the Austin and Northwestern Railroad in the early 1880s. By 1900-1910, the local economy was dominated by the production of stock and crops, and by the cutting and marketing of cedar products. The 1930s brought a period of economic depression that was alleviated somewhat by employment opportunities offered during the construction of dams on the Colorado River. The project area was traversed briefly by one feature associated with that construction activity - the Marshall Ford Dam railroad, used to transport construction and other supplies from the main rail line at Rutledge to the dam site.

During the 1940s, the face of the project area changed dramatically when the State Board of Control, seeking to acquire rural land a convenient distance outside the Austin city limits, purchased the 305-acre Dedear farm adjacent to present-day U.S. Highway 183 . Needing a site that could accommodate a swine and dairy operation and alleviate overcrowding in existing state institutions, the Board purchased the farm in 1942 and began operating the State Dairy and Hog Farm by 1943. Threatened closure of the Austin abattoir, increasing scarcity of food products brought on by the war effort, and the Board's desire to make Austin's eleemosynary institutions as self-sufficient as possible led to redevelopment of the Dedear property as a dairy operation and acquisition of the adjoining Rhodes farms in 1945 for an expanded swine operation.

Between 1942 and the early 1950s, facilities at the State Dairy and Hog Farm consisted of buildings constructed before 1942 at the Dedear and T. W. Rhodes farms, new construction that probably was designed by Board architect Walter C. Moore and his staff, and Civilian Conservation Corpsconstructed buildings from Longhorn Cavern that were declared surplus after World War II. The 
Figure 7. Historic properties at the State Hog Farm, 1955. 
early to mid 1950s brought with them a refocusing of farm activities as the dairy operation ceased and hog production doubled. Between 1950 and 1955, buildings were constructed on the Rhodes tract to accommodate a new swine operation. Further redevelopment occurred after the late 1960s when agricultural use ceased and the newly designated Leander Rehabilitation Center carried out an educational and recreational mission.

Today, a number of resources testify to the earlier agricultural use of the property. Believed to be the only major state eleemosynary institution constructed in Texas during World War II, the State
Dairy and Hog Farm played an important role in the healing of patients, while also filling the needs of Austin-area institutions for dairy and meat products. During the 1950s and 1960s, exclusive refocus of the farm on hog production and development of innovative feeding techniques enabled the employees and patients to supply meat to institutions throughout the state (Wynn 1996). Until 1970 the State Hog Farm was a functioning element in a system whose intent was to further the self-sufficiency of the state's eleemosynary institutions. For the most part, those resources date from ca. 1943 to 1969 , the period of most intensive development and use of the property. 



\section{METHODS OF INVESTIGATIONS}

This chapter outlines the methods used for the Phase I cultural resource investigations at the Leander Rehabilitation Center. Archeological, architectural, and archival research methods are described below.

\section{ARCHEOLOGICAL RESEARCH}

Prior to the archeological survey, a site file search was conducted at the Texas Archeological Research Laboratory, The University of Texas at Austin. Several prehistoric and historic sites were noted adjacent to the project area, and one site (41WM452) appeared to extend into the project area. The nine prehistoric sites include a rockshelter, four lithic scatters, two burned rock midden sites, and two open campsites (Fox and Whitsett 1984; Whitsett 1981). The two previously recorded historic sites near the project area relate to the Rutledge settlement and date to the late nineteenth and early twentieth centuries (Mercado-Allinger and Ragsdale 1984).

The project area was visited before the fieldwork to familiarize personnel with the project area boundaries, topography, and geomorphic settings. This allowed the Project Archeologist and Principal Investigators to divide the project area into areas of high, moderate, and low potential for the presence of intact prehistoric sites (Figure 8). Areas designated as high probability were located along the northern and northwestern margins of the project area, along South Brushy and Buttercup Creeks. These areas make up less than 5 percent of the project area. Moderate probability areas consisted of the slightly dissected and gently sloping upland areas overlooking the valleys of South Brushy and Buttercup Creeks. Low probability areas consisted of the nearly level and undissected upland areas away from the stream valleys. A subsequent meeting with representatives from the GLO and the Texas Historical Commission confirmed the delineation of areas of high, moderate, and low archeological site potential. Areas with the potential for historic archeological sites were determined after archival investigations were conducted and aerial photography and maps examined. The documentation of historic period archeological resources focused on localities, features, and components predating the establishment of the State Dairy and Hog Farm.

Once areas of site potential were determined, a 100 percent pedestrian survey was conducted by walking systematic transects over the project area. In areas of high probability, transects were spaced at 10-20-m intervals, depending upon conditions (density of vegetation, ground exposure, etc.). Limited off-site shovel testing was also employed in these areas as a means of site detection. Areas of moderate probability were surveyed at $20-40-\mathrm{m}$ intervals, and low probability areas were surveyed using transects spaced at $40 \mathrm{~m}$ or more. Areas with a high potential for historic period sites were thoroughly field checked. Black-and-white aerial photographs $(1 \mathrm{inch}=300 \mathrm{ft})$, legal plat maps, and USGS 7.5' topographic maps were used to navigate over the project area. Areas devoid of dense vegetation, whether natural or artificial, were closely examined for any evidence of cultural materials such as burned rocks, historic artifacts (glass, ceramics, metal, etc.), lithic debitage, mussel shells, and stone tools. The areas closely examined included (but were not limited to) animal burrows, drainage cutbanks, roadcuts, shallow drainages, and deflated areas. When cultural materials were located, an intensive survey of the immediate area was conducted to 


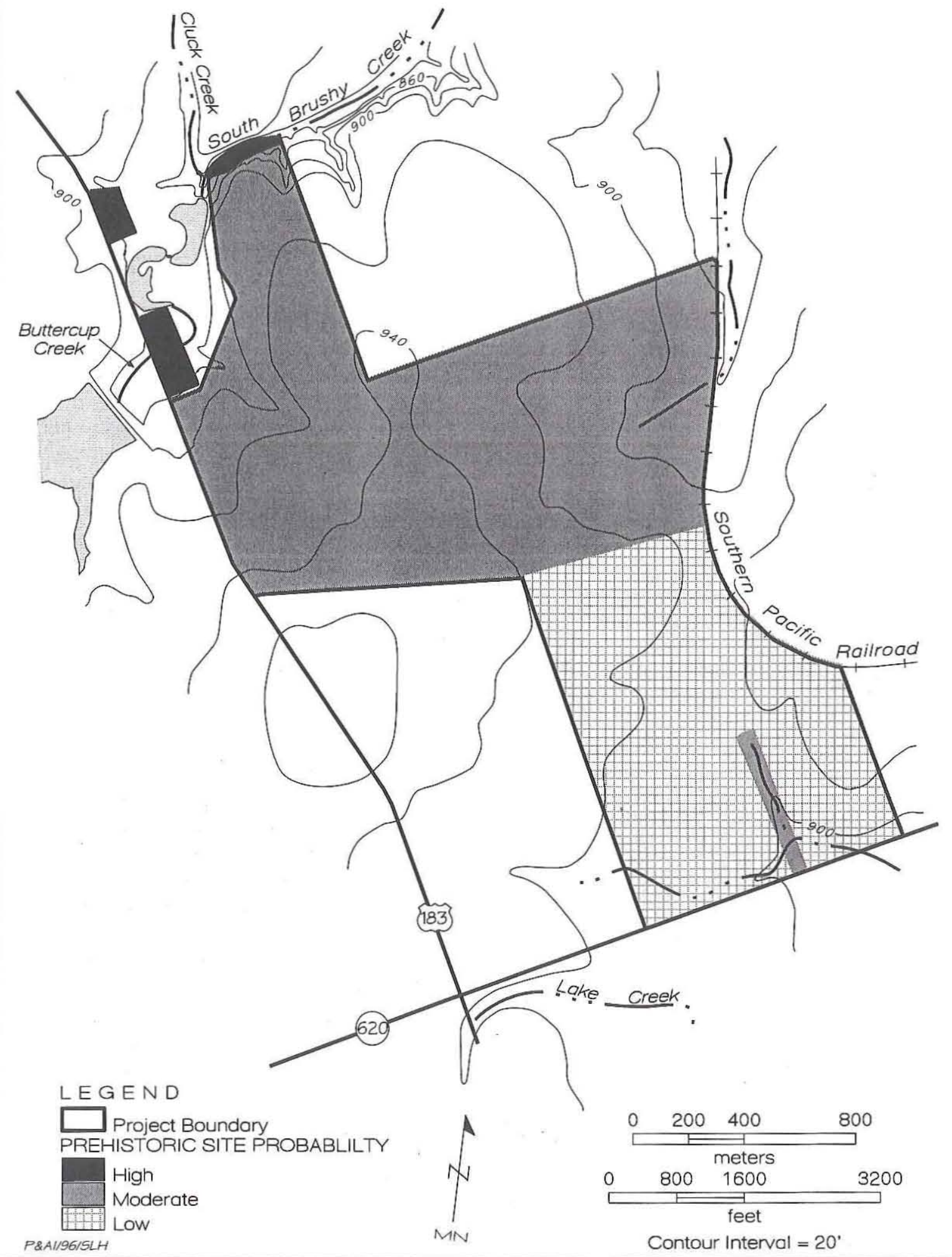

Figure 8. Areas of high, moderate, and low prehistoric site probability. 
locate concentrations of artifacts or features. Shovel tests were excavated, unless exposed bedrock or less than $10 \mathrm{~cm}$ of sediment was present. All shovel tests, including off-site tests, were excavated in $20-\mathrm{cm}$ levels. All excavated matrix was screened through $1 / 4$-inch-mesh hardware cloth. Only diagnostic artifacts and artifacts recovered from shovel tests were collected and labeled with appropriate provenience data. Temporally sensitive historic artifacts (e.g., glass or ceramics with makers' marks or with distinctive decorations) were also collected. Site documentation included the completion of State of Texas Archeological Site Data Forms, sketch maps, and photographs. All field records were kept in a standard format and included a daily journal, shovel test records, project area maps, aerial photos, and photograph logs. The field survey required 33 person-days of effort.

\section{ARCHITECTURAL RESEARCH}

The Project Architectural Historian conducted a comprehensive reconnaissance-level survey of all nonarcheological buildings, structures, sites, and objects built before 1952 to evaluate their potential eligibility for listing in the National Register of Historic Places or for designation as State Archeological Landmarks. Thirty-six sites (some with multiple secondary features) totaling 45 resources were surveyed. Among them are single-family dwellings, barns, sheds, dormitories, water and feed troughs, a truck scale, an office and warehouse, and infrastructural elements such as culverts, fencing, and a septic system.

Prior to beginning fieldwork, the Project Architectural Historian reviewed historic maps, including USGS and state highway maps, archival information, and a preliminary narrative history of the farm prepared by the Project Historian. The map review provided information on buildings and structures present at given dates. However, such data typically are not comprehensive and can be used only as a guide to the extent of development at any given period, not as definitive documentation. The review of archival data and the preliminary narrative history identified administrative decisions and agricultural programs that affected the construction of buildings and structures and the overall development of the State Dairy and Hog Farm. Questions remained, however, regarding the dates of construction and original uses of many buildings.
The single day of fieldwork involved a reconnaissance-level survey conducted on foot and by vehicle. Each nonarcheological building, structure, site, and object thought to have been built before 1952 was documented on a field record form, noting the approximate date of construction in increments of five years, approximate date of alterations (if any), type of alterations (if any), resource type (building, structure, site, or object), property type (domestic, agricultural, or infrastructural), property subtype (if any), condition, and exterior materials. A preliminary property evaluation was then assigned to each recorded resource, using the following designations: High, Selected Medium, Medium, Selected Low, or Low. These categories were assigned based on preservation potential after assessing the visual characteristics of the resources, their condition, and their architectural integrity using National Park Service guidelines for assessing integrity and potential National Register of Historic Places eligibility; Table 2 explains these categories in more detail. Each resource was plotted on a current USGS map using the unique site number assigned during the survey process. Sites with a primary resource and related secondary resources, such as a dwelling and a garage, were assigned a site number followed by a letter (e.g., $2 a$ and $2 b$ ). Numbers affixed to some of the resources, such as $600 / 8120$, also were recorded. In some cases, one or both of these numbers are missing. In those situations, the missing numbers were indicated by a question mark. 'The 600 series numbers may date to the facility's operation as a dairy and hog farm. The 8000 series may reflect new numbering assigned when the farm became the Leander Rehabilitation Center. In addition, one black-and-white photograph and two color slides were taken of each surveyed property, and identifying information on each photograph was recorded on photo identification sheets.

Subsequent to the fieldwork, the Project Architectural Historian met with Department of Mental Health and Mental Retardation staff member Roy Jones to review existing site plans and architectural drawings for the State Dairy and Hog Farm. The majority of the available drawings and maps date from the 1970s and are not pertinent to the historic period. The original drawings would have been important keys in documenting the development of the farm and in assessing the relative architectural significance of the buildings and structures there. Regrettably, the original plans for the farm were 


\begin{tabular}{|c|c|}
\hline & $\begin{array}{c}\text { TABLE } 2 \\
\text { EXPLANATION OF PROPERTY EVALUATION CATEGORIES }\end{array}$ \\
\hline Category & Discussion \\
\hline High Priority & $\begin{array}{l}\text { These resources are considered the most significant in a survey area, retain a high degree of } \\
\text { physical and architectural integrity, have few alterations, and possess strong associations with the } \\
\text { historic context. They are most likely to meet one or more of the eligibility criteria for listing } \\
\text { in the National Register of Historic Places. They may be individually eligible for National } \\
\text { Register listing. If included within the boundaries of a National Register historic district, they } \\
\text { are almost always considered Contributing resources to the district. }\end{array}$ \\
\hline $\begin{array}{l}\text { Selected Medium } \\
\text { Priority }\end{array}$ & $\begin{array}{l}\text { These resources have less architectural integrity and possibly less historic significance than } \\
\text { properties in the High category, but they are unusual property types or architectural styles, use } \\
\text { unusual construction methods, or for some other reason indicate a potentially significant history } \\
\text { in relation to development patterns. While they may meet one or more National Register } \\
\text { eligibility criteria, they are less often individually eligible for the National Register because of } \\
\text { alterations that have removed or obscured important character-defining design features. If } \\
\text { included in a National Register historic district, they are almost always considered Contributing } \\
\text { resources to the district. }\end{array}$ \\
\hline Medium Priority & $\begin{array}{l}\text { These resources usually have less integrity than those identified as High or Selected Medium } \\
\text { properties. They are almost always characterized by alterations or deterioration of materials that } \\
\text { have removed, changed, or obscured original design features, or by less-significant associations } \\
\text { with the historic context. As such, they are not generally considered individually eligible for the } \\
\text { National Register. If included in a National Register historic district, they are almost always } \\
\text { considered Contributing resources to the district. }\end{array}$ \\
\hline $\begin{array}{l}\text { Selected Low } \\
\text { Priority }\end{array}$ & $\begin{array}{l}\text { These resources are those that are not yet } 50 \text { years of age and do not meet the National Register } \\
\text { criteria considerations for exceptional properties. They are, however, unusual property types, or } \\
\text { are unusual or significant architectural styles, or employ unusual or significant methods of } \\
\text { construction, or for some other reason indicate a relationship to development patterns that will } \\
\text { become significant as more time passes. These properties often possess a high degree of } \\
\text { architectural integrity and display well-defined characteristics associated with Modernism or } \\
\text { another architectural or engineering development, which, while not currently exceptional, will be } \\
\text { increasingly important as resources built in the 1950s and thereafter become } 50 \text { years old. These } \\
\text { also may be resources that are } 50 \text { years old or older and that have been significantly altered but } \\
\text { may be important for their historical associations. Although they are unlikely to be eligible for } \\
\text { National Register listing individually, they may reveal useful information about the development } \\
\text { of a community, a neighborhood, or a facility. In rare cases, they may be eligible for listing on } \\
\text { the National Register for the information they can provide about building technology or for } \\
\text { archeological reasons. If located within a National Register historic district, they are usually } \\
\text { considered Noncontributing resources within the district. }\end{array}$ \\
\hline Low Priority & $\begin{array}{l}\text { These resources have less significance than those in the other categories. They may be properties } \\
\text { built at the very end of the historic period which have lost most of their original character- } \\
\text { defining architectural elements through modifications, or they may represent types still highly } \\
\text { common and widely found. They do not generally meet National Register criteria. If located } \\
\text { within a National Register historic district, they are usually considered Noncontributing resources } \\
\text { within the district. }\end{array}$ \\
\hline
\end{tabular}


apparently discarded in 1993 when the facility closed. However, Mr. Jones was able to provide information about Leonard Wynn, storekeeper/ accountant and business manager of the State Dairy and Hog Farm between 1945 and 1969. A site visit with the Wynns was arranged, during which the Project Historian and the Project Architectural Historian conducted an oral interview with the Wynns and their daughter Elaine Albritton. They provided information about the development of the farm, approximate dates of construction for most of the extant resources, and an understanding of the programs and activities of the facility in those years.

Upon conclusion of the site visit and oral interview, the Project Architectural Historian correlated archival data about which there were questions with information gained in the interview to accurately revise dates of construction for several of the buildings and structures included in the architectural survey. Information gained from the informants also clarified the original uses of many of the buildings and allowed for an understanding of the functional relationships of the extant resources.

The final steps of the project focused on the preparation of the report and the supporting survey materials. Information from the field photograph log sheets was prepared. Labels for the $35-\mathrm{mm}$ slides were prepared and affixed to the slides in site number order, and the photographic materials (35-mm black-and-white contact sheets, photograph identification sheets, $35-\mathrm{mm}$ black-and-white negatives, and $35-\mathrm{mm}$ color slides) were compiled into three-ring presentation notebooks.

\section{ARCHIVAL RESEARCH}

Archival research focused on collecting information about the history of the land comprising the State Dairy and Hog Farm prior to its purchase by the state in 1942 and 1945 and collecting other data to identify sites, buildings, and structures that were constructed by the state after 1942 . Research began with visits to the Williamson County Courthouse and General Land Office for the purpose of compiling legal abstracts and identifying areas that might have a high probability of containing historic sites. In addition, the Project Historian examined aerial photographs. This initial phase of research resulted in the identification of a railroad bed constructed by the Lower Colorado River Authority in the 1930s and two pre-1942 farmsteads, belonging to the Kooch and Dedear families.

Additional research was conducted at the Department of Mental Health and Mental Retardation, the Center for American History, the General Land Office, and the State Library and Archives. At the Archives, the Project Historian examined all files of the State Board of Control for the period 1940-1960, looking for information about the State Dairy and Hog Farm specifically, and about state eleemosynary institutions in general. Supplementary information was obtained from the Austin History Center and the offices of the Williamson County Sun. An additional visit was made to the county clerk's office seeking information about an earlytwentieth-century site (41WM892) that was recorded during the fieldwork. 
, 


\section{RESULTS OF INVESTIGATIONS}

This chapter presents documentation on the one prehistoric and four historic archeological sites recorded within the project area. Documentation and architectural information on 45 buildings and structures within the project area are also presented, as well as the results of the archival research.

\section{ARCHEOLOGICAL SITES}

The archeological survey extended the site boundaries of one previously recorded prehistoric site (41WM452) and recorded four historic sites (41WM892, 41WM893, 41WM896, and 41WM897) (Figure 9). The survey consisted of a 100 percent pedestrian survey of the project area and off-site shovel testing in high and moderate probability areas. In total, 13 off-site shovel tests were excavated. Five shovel tests (Shovel Tests 13-17) were excavated on the $T_{1}$ terrace of South Brushy Creek. The depths of these shovel tests ranged from 23 to $32 \mathrm{~cm}$, and the tests were terminated after encountering dense gravels. No cultural materials were recovered. Four shovel tests (Shovel Tests 1-4) were excavated near or adjacent to Buttercup Creek. The depths of these shovel tests ranged from 8 to $30 \mathrm{~cm}$. The gravelly silty clay loam prevented deeper excavations. No cultural materials were recovered in these shovel tests. Four shovel tests (Shovel Tests 9-12) were excavated in two moderate probability areas. Shovel Tests 9 and 10 were excavated to 11 and $15 \mathrm{~cm}$, respectively. Excavations were impeded by the gravelly black silty clay loam. Shovel Tests 11 and 12 were excavated to 33 and $32 \mathrm{~cm}$, respectively, on the north side of a shallow ephemeral drainage. No cultural materials were recovered from Shovel Tests 9-12.

\section{Site 41 WM452}

\section{Description}

Site $41 \mathrm{WM} 452$ is an upland lithic scatter and lithic procurement site, previously recorded by Fox and Whitsett (1984) on an adjacent property as a Late Archaic open quarry/occupation site measuring $900 \mathrm{~m}$ (north-south) by 2,000 m (east-west). They collected a Montell dart point fragment from the site. The current investigations revisited the site and extended the boundaries, enlarging it to $1.3 \mathrm{~km}$ (north-south) by $2.5 \mathrm{~km}$ (east-west). The site is limited to the generally undissected upland plateau surface, which is severely deflated and consists of very thin discontinuous patches of dark brown to black clayey and silty sediment, exposed bedrock, and residual chert cobbles.

\section{Cultural Materials Observed and Collected}

Lithic debitage and tested chert cobbles were observed scattered across the surface. The collection of two temporally diagnostic artifacts, Pedernales and Marshall dart point fragments (Figure 10), suggests that the site was utilized during the Late Archaic period.

\section{Assessment}

The lack of depth and site stratigraphy and the potential presence of overlapping and mixed temporal components severely limit the information that this site could provide. It is recommended that 41WM452 be considered not eligible for listing in 
Figure 9. Archeological sites and off-site shovel test locations. 

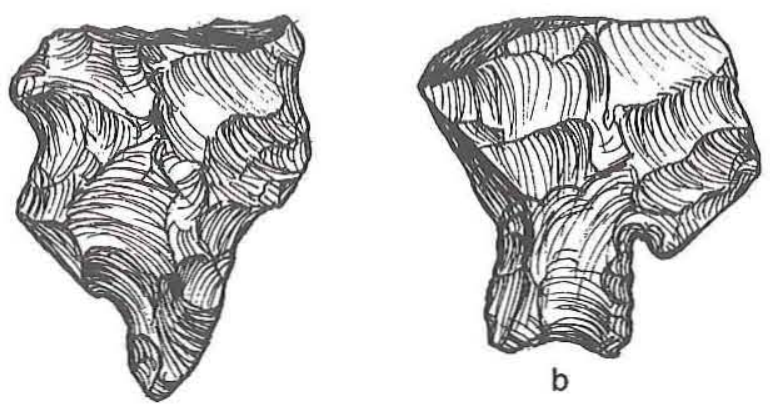

a

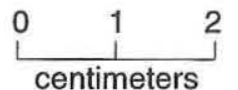

Figure 10. Dart points from 41WM452. (a) Marshall; (b) Pedernales.

the National Register of Historic Places or for designation as a State Archeological Landmark.

\section{Site 41 WM892}

\section{Description}

Site 41 WM892 consists of a series of historic rock features and artifact scatters. As described below, several lines of evidence indicate that the site represents a group of campsites associated with historic wood chopping for the production of cordwood: (1) deed records show that the surrounding tracts were leased to wood choppers during the first decade of the twentieth century; (2) the artifacts at the site date to a range that includes this period; (3) the site has features that are not consistent with what would be expected at a typical farmstead or ranchstead; and (4) no other candidates for a wood chopper's camp were found during the survey. One of the features at $41 \mathrm{WM} 892$ reportedly represents a dugout associated with an unknown African American occupant, but the relationship between this possible occupation and the wood-chopper component remains unknown.

The site lies in an upland area densely wooded with juniper trees. A small ephemeral tributary of South Brushy Creek runs through the middle of the site. Soils across the entire site are extremely shallow. Limestone bedrock occurs very close to the surface in most places. As a result, artifactual deposition is also shallow, and the materials within 41WM892 are surficial. Because of the lack of deposition, there is no potential for a subsurface component, and thus shovel testing was not done.
The site consists of three separate areas (Areas $1-3)$, but based on their proximity to one another and archival evidence of corporate activity suggesting cohesiveness, the three areas are designated as one site (Figure 11). These areas have concentrations of features and artifacts that could represent either different activity areas or simply separate campsites. All three areas have one characteristic in common. All have rock alignments that appear to be the remains of rock walls. The rocks utilized for this construction are the naturally occurring Edwards limestone which is subaerially exposed over much of the project area. The limestone tends to weather to very irregular shapes and configurations, exhibiting many holes and uneven surfaces. This material is not well suited to dry-laid construction techniques since it does not stack squarely. The walls at 41WM892 appear to have been constructed simply by piling stones on top of one another, not in courses and without mortar. As a result, all of the rock alignments at the site have now slumped and exist only as low mounds. There are not enough

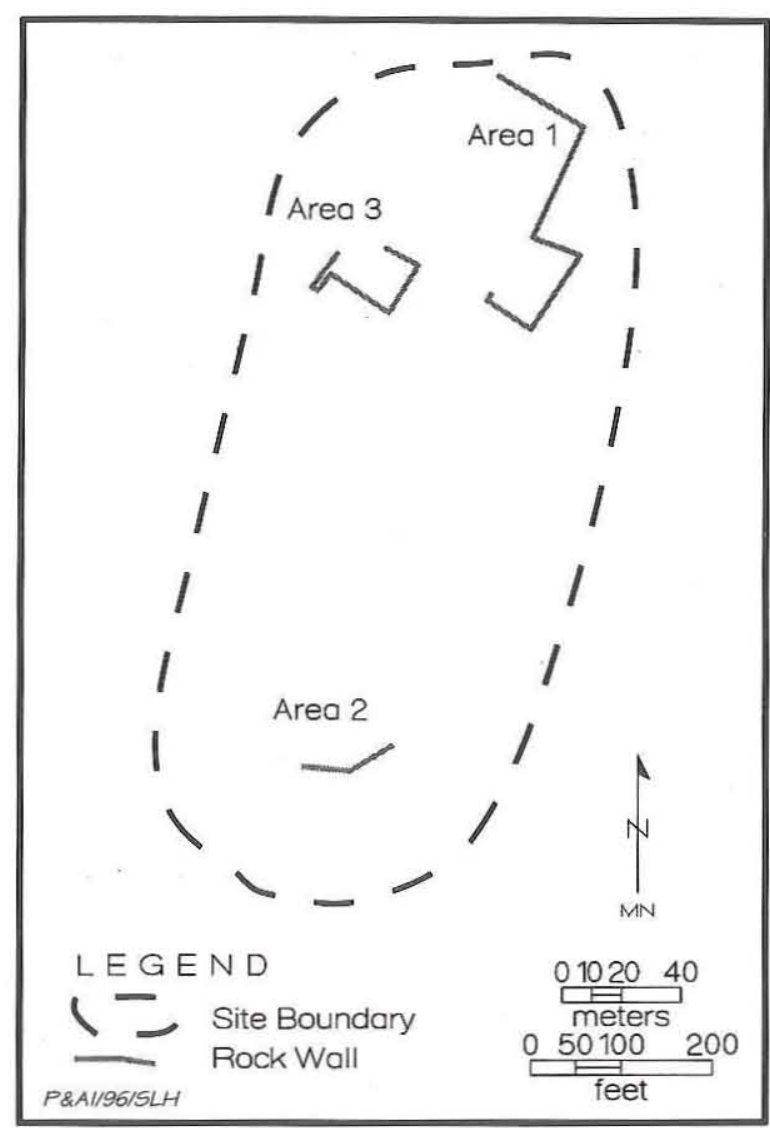

Figure 11. Map of site 41WM892. 
rocks in and adjacent to the alignments to have formed walls more than about a meter high, and thus if the alignments do represent fences (e.g., for livestock), they may have been topped by brush or logs to extend them to a functional height. There is no evidence of any other fencing materials such as posts, wire, nails, or fencing staples. Another possible function for the alignments is that they served as soil retaining walls, although this does not seem likely given their irregular configurations and their placement on the landscape.

Area 1 is located in the northernmost part of the site. It has one continuous alignment which forms roughly two areas: a three-sided rectangular area to the south and a squared corner to the north (Figure 12). The wall is built of natural rocks averaging 30 to $50 \mathrm{~cm}$ in length. Most of the wall survives to no more than $50 \mathrm{~cm}$ in height. The southern rectangular area, measuring ca. $32 \times 18 \mathrm{~m}$, does not have a wall on its western side. It is possible that a western wall was once present but has been destroyed. However, all of the remaining wall retains visible stone construction. The vicinity of the rock wall is now overgrown with dense juniper. The rock wall may have served as an enclosure for livestock, such as mules used as draft animals.

Area 1 also has another much smaller and functionally different enclosure (Figure 13). This feature is located near the rock alignment and is identical in the type of construction but is not part of the alignment. This feature is a fully enclosed, roughly rectangular shape, oriented northeast-southwest along its long axis. The enclosure is approximately $6 \mathrm{~m}$ long by $5 \mathrm{~m}$ wide. The walls enclose a large depression approximately $1.2 \mathrm{~m}$ deep. The subterranean portion is unlined, but rocks from the walls and copious amounts of leaf litter have accumulated in the depression, thus suggesting the interior was originally even deeper.

According to a story told to an informant, this subterranean feature was a dugout dwelling once occupied by an "old Black man" (Albritton 1996). Reportedly, the dugout had a lean-to roof and was occupied sometime in the period ca. 1900-1910. It is unclear if this structure was related to cedar chopping activities on the land. Given the known information, it is not possible to determine who constructed the feature. The exact relationship and chronology between the cedar choppers and the possible Black occupant are also unclear, especially

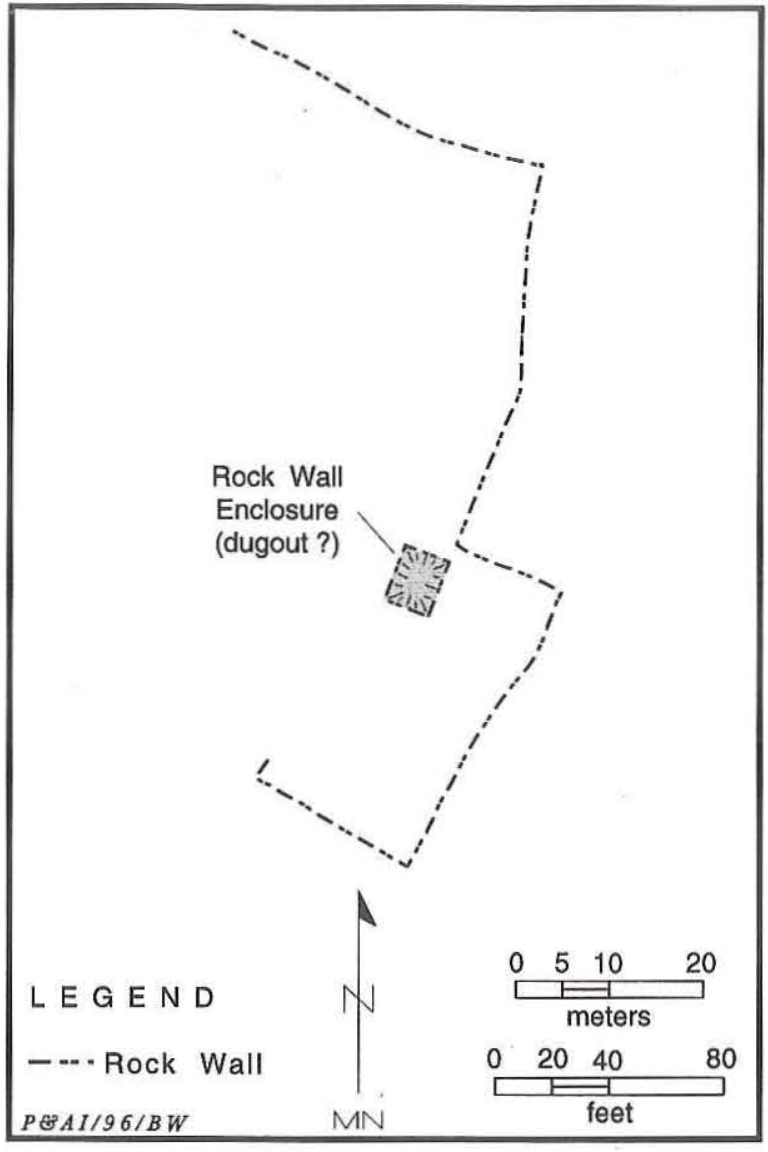

Figure 12. Plan view of $41 \mathrm{WM} 892$, Area 1.

considering the possibly overlapping periods of use. The only artifacts present in this area of the site are two sheet metal fragments. The lack of any other artifacts in this area makes the question even more puzzling.

Area 2 is the southernmost area of the site, and it is the only area that lies south of the small drainage that runs through the site area. One defined rock alignment lies in the eastern portion of this area. From its western end, it runs in an easterly direction for $30 \mathrm{~m}$, then takes a $55^{\circ}$ turn and runs for another $23 \mathrm{~m}$ (Figure 14). At the western end of the wall is a rock pile, the function of which is unknown. The function of the alignment itself is also unclear. It could have functioned as a boundary wall, but it is unclear what boundaries would have been delineated within a wood-chopper camp. It is more likely that this alignment is a remnant of a larger enclosure for livestock.

Several other rock piles are also located within Area 2. They are not well defined, and it is possi- 


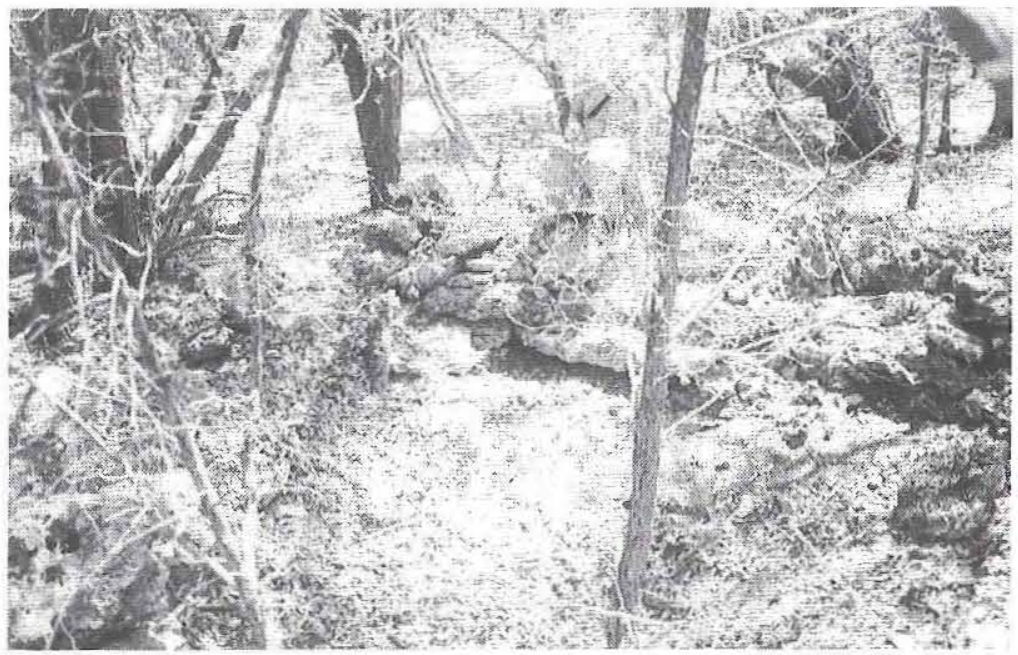

Figure 13. View north of stone enclosure in Area 1 of 41 WM892. appears that the original shape of the pen was roughly rectangular or ovate, with a south-facing opening, possibly for a gate. The enclosure is oriented northwest-southeast along its long axis. Though the walls have fallen, the interior dimensions are approximately $8.5 \times 4 \mathrm{~m}$. This would be an appropriate size and shape for a pen to hold one, or maybe two, animals. According to the timber deed (Deed Record 113:599), the wood choppers could have no more than eight horses or mules on the land at a time, and therefore individual workers might have had smaller enclosures or pens for ble that these piles could be the fallen remains of rock walls. One feature where this is most likely the case is a possible animal pen/enclosure in the southern part of Area 2 (Figure 15). The northeastern portion of the enclosure wall has now been disrupted by the growth of a juniper tree, but it single animals.

A light scatter of artifacts is present in the western portion of Area 2. This scatter is not associated with the rock alignment or with the rock enclosure/pen. There are three rock piles within the area of the scatter, and one of these is associated

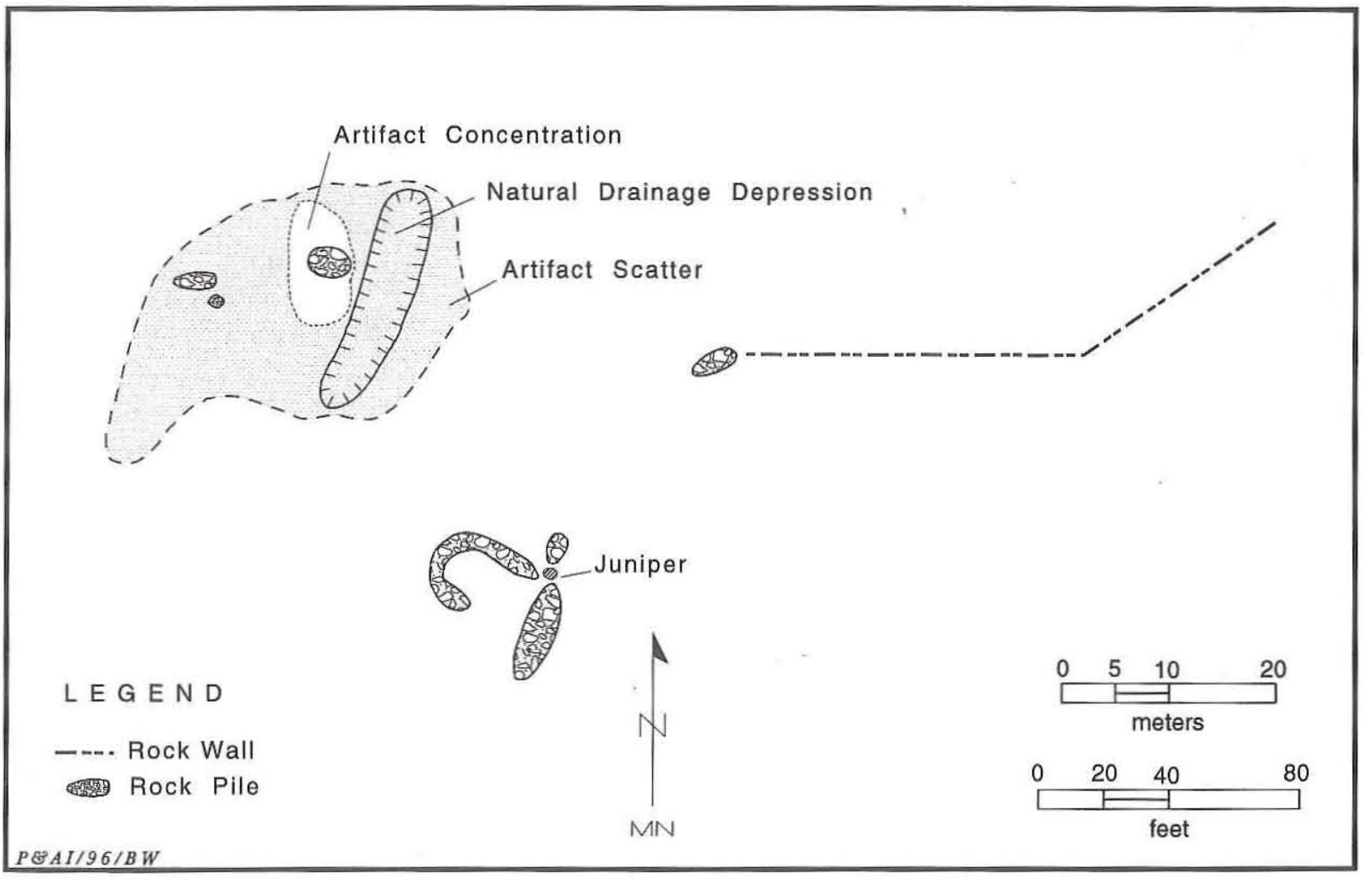

Figure 14. Plan view of 41 WM892, Area 2. 


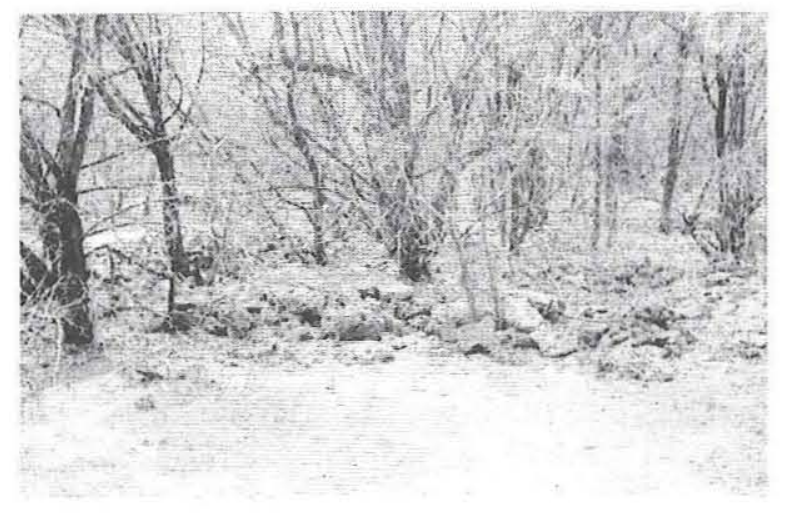

Figure 15. View south of stone enclosure in Area 2 of 41WM892.

with the most concentrated part of the scatter. The meaning of this spatial distribution and the relationship between the artifacts and rock piles are unclear. However, it is possible that both material refuse and construction refuse (excess rocks) were dumped or disposed of in this vicinity, taking advantage of a natural drainage depression.

Area 3 is located in the westernmost part of $41 \mathrm{WM} 892$, north of the drainage. Of the three areas that make up this site, Area 3 appears to be the most intact. The features in this area include a large rock wall enclosure, a circular depression, and an artifact scatter (Figure 16).

The rock wall enclosure in this area is constructed in the same manner as the other rock walls and enclosures at the site. It is made of natural unmortared limestone. These walls create a complete rectangular enclosure, and rocks are visible along almost its entire length. The exception is one $8.5-\mathrm{m}$ section of wall at the northwestern corner of the enclosure which is visible only as a low earthen berm covered with juniper needles. The enclosure is oriented northwest-southeast along its long axis. It is approximately $32 \mathrm{~m}$ long, and its width ranges from 15 to $20 \mathrm{~m}$, with the structure being larger at its southeastern end. The southwestern corner of the enclosure has a 7.5-m projecting section which is $2 \mathrm{~m}$ wide. It forms a sort of closed "chute." Of all the rock features within 41WM892, this one is the most obvious animal enclosure.

The next feature within Area 3 is a large depression to the west of the enclosure. This depression is circular, with a diameter of $3 \mathrm{~m}$ and a depth of

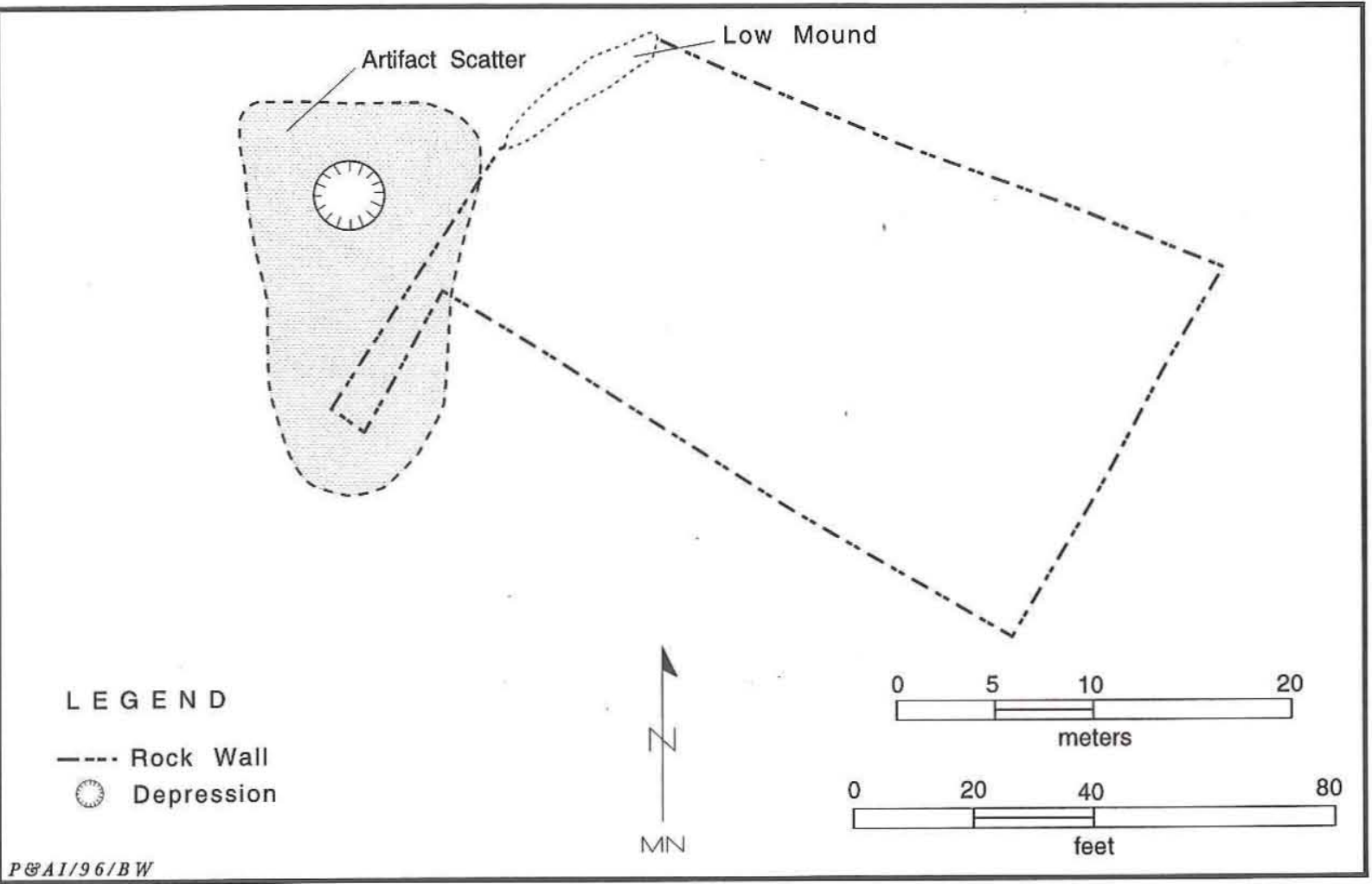

Figure 16. Plan view of 41WM892, Area 3. 
approximately $0.75 \mathrm{~m}$. The depression is shallow and sloping in cross section. Though not well suited for water storage in and of itself, it might have been a location where a metal tank cistern was placed. In this case, it would have been convenient to the livestock enclosure.

The final feature of Area 3 is a surface artifact scatter in the vicinity around the depression and the chute projecting from the enclosure. These artifacts are discussed in detail below.

\section{Cultural Materials Observed and Collected}

Areas 2 and 3 have artifact scatters, each having fewer than 50-75 items, while Area 1 does not. Materials observed on the surface in Area 2 include undecorated ironstone, enameled tin kitchenware, clear container glass, opaque light blue glass, machinery parts, monochrome green decal ironstone, molded porcelain, solarized glass, stoneware with a greenish brown slip glaze, and olive green bottle glass. A surface collection of diagnostic materials from the Area 2 artifact scatter consists of the following: molded soft-paste porcelain $(\mathrm{n}=1)$; decal-decorated whiteware $(\mathrm{n}=1)$; slip-glazed stoneware jug sherds $(n=4)$; a fragment of an unidentifiable Royal Arms-type maker's mark from Burslem, England, printed in black on an undecorated ironstone sherd $(n=1)$; olive green bottle base $(\mathrm{n}=1)$; slightly solarized container glass with embossed letters ". . . DIS . . . . . ANSAS CIT ..." (n = 1); slightly solarized panel bottle fragment with embossed letters " $\mathrm{CH}$..." $(\mathrm{n}=1)$; slightly solarized bottle finish $(n=1)$; flint container glass with embossed letters ". . . MO.U ..." $(n=1)$; clear glass screw-top bottle finish $(n=1)$; light blue table glass $(n=1)$; and a cast iron handle $(n=1)$. These types of artifacts are consistent with an occupation from the late nineteenth century to the early twentieth century.

Materials observed in Area 3 include monochrome blue decal ironstone, stoneware with brown slip glaze, brown snuff bottle fragments, clear container glass, enameled tin kitchenware, a galvanized metal bucket, leather shoe parts (including metal eyelets and a nailed heel), an auto fender and tire (possibly Model A), an oil can, and tin cans. A surface collection of diagnostic materials from this area consists of the following: green floral decaldecorated whiteware $(\mathrm{n}=1)$; undecorated whiteware $(n=1)$; Albany-type slip-glazed stoneware $(n=4)$; snuff bottle shoulder fragment $(n=1)$; clear container glass $(\mathrm{n}=1)$; solarized container glass $(\mathrm{n}=1)$; and a four-hole sew-through white porcelain button $(n=1)$. Many of these items are large and appear to have been deposited as refuse (dumped) as opposed to being primary deposits associated directly with a specific activity. These artifacts are also consistent with an occupation during the period between the late nineteenth century and the first decade of the twentieth century.

\section{Site History}

Site 41 WM892 is located on lot 11 of the Morgan C. Hamilton Subdivision of the Rachel Saul League. The Saul League was granted to George Washington Glasscock of Williamson County on September 16, 1847 (Deed Record 31:159-160), and Glasscock sold one-quarter of the league (1,107 acres) to Morgan C. Hamilton of Travis County on May 22, 1854 (Deed Record 5:370-371). Hamilton, state comptroller in 1867, delegate to the Constitutional Convention in 1868-1869, U.S. senator from 1870 to 1877, and brother of Reconstruction governor Andrew Jackson Hamilton (Texas State Historical Association 1996:3:430; Webb 1952:I:760), subdivided the quarter league into 14 lots (Figure 17) which he classified according to their usefulness. Of lots 11 and 12 , Hamilton stated that they had "pretty good timber and good land for cultivation" (Deed Record 27:226-227).

On October 29, 1881, Hamilton sold lots 11 and 12 to N. B. Mays of Travis County (Deed Record 39:40-41). Four years later, Mays sold the lots to Dr. C. A. Graves of Travis County, who already owned lots 5, 9, 10, 13, and 14 (Deed Record 34:130-131). Graves held the land until May 1, 1895, when he sold the portions of lots 5, 11, and 12 west of the Austin and Northwestern Railroad to Isabella Green of Travis County (Deed Record 73:180-181). Green and other individuals then became parties in a legal dispute with W. E. Armstrong and John Tyler, who recovered a judgment against Green and her associates. Settlement in favor of Armstrong and Tyler resulted in the public auction of all of lot 12 and the portions of lots 5 and 11 lying west of the railroad, and on March 1, 1904, the two men became the new owners of the property (Deed Record 111:339-342).

Shortly after settlement of the lawsuit, Armstrong sold his interest in the Williamson 


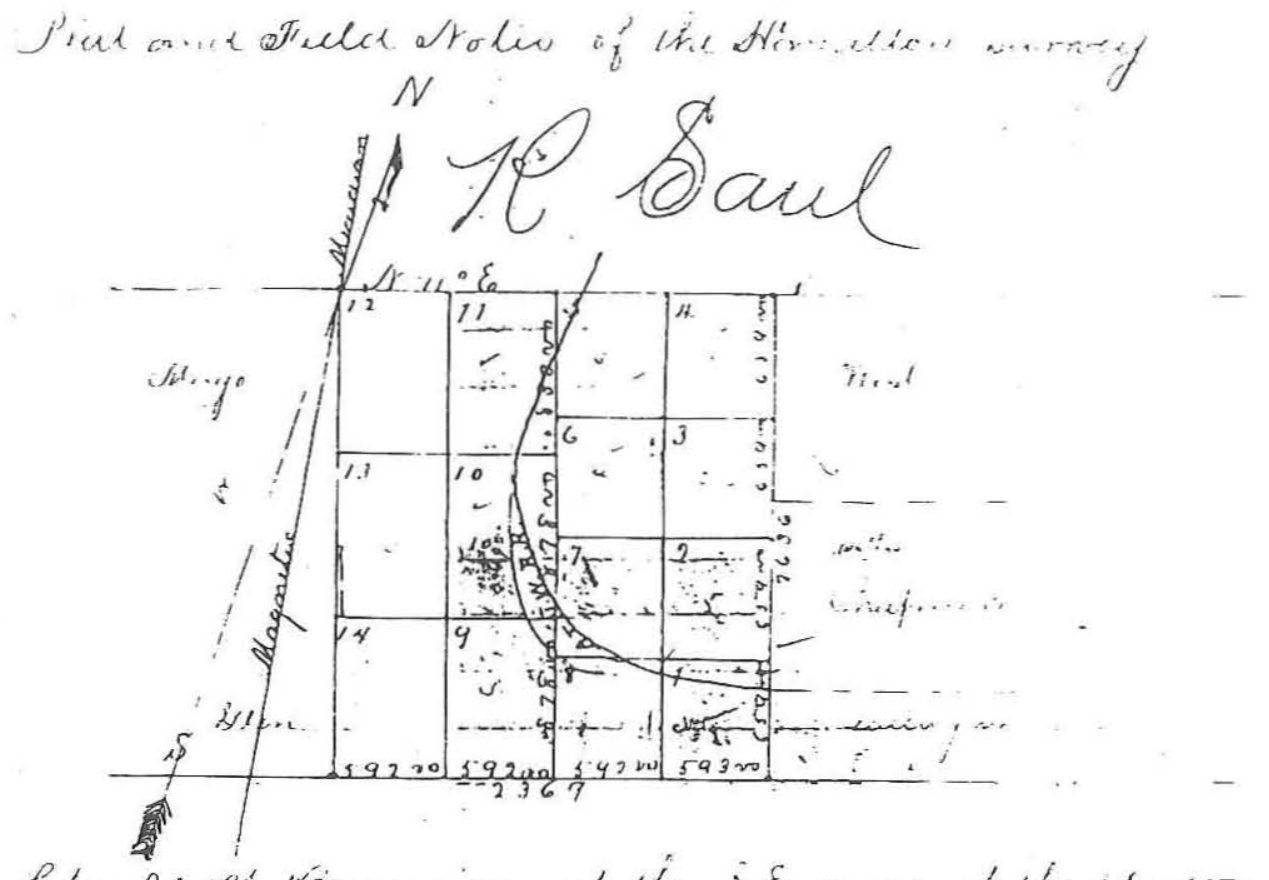

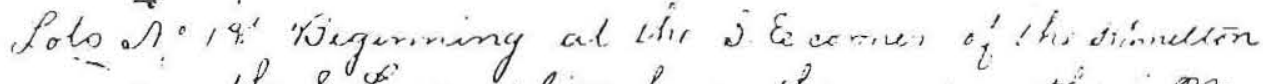
surray on the \&. Seague lino. berng the pame as the is of corner of Milligans tract a stahi in a sione mzownel, chance \&n. It along the Leagueline 543 varas a clate, wn a do tone mound; Ghence. If 19091659 varas a done maind thence S. 7 E 5 3 varas a otone mound on the line betwren form-

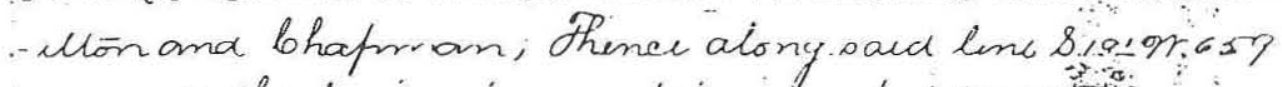
varas to the frgiming eontaining al-out 690 icicici-

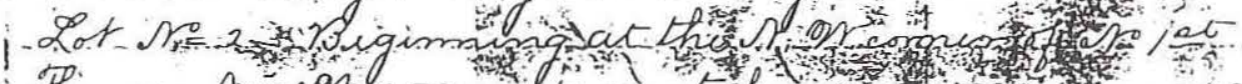

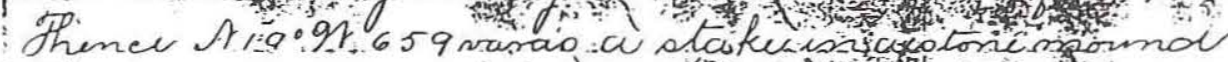

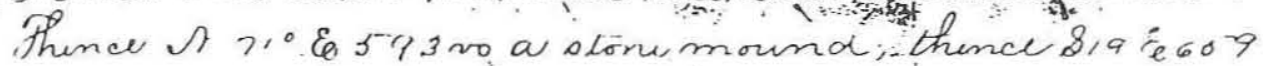
varas along tramellon and bhajproms hine a stove mond

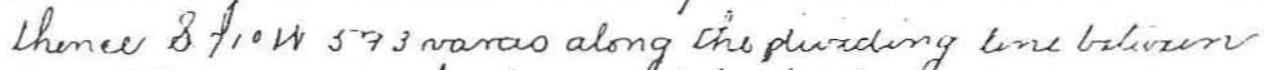

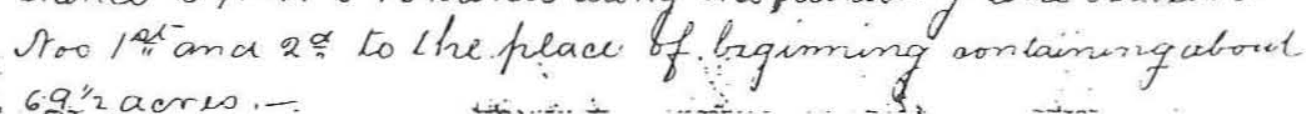

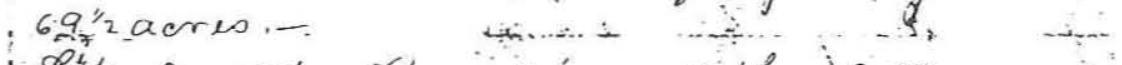

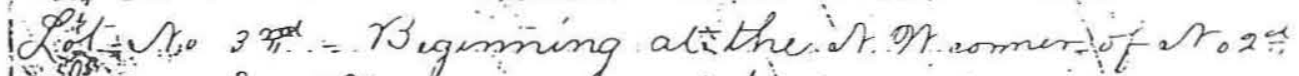

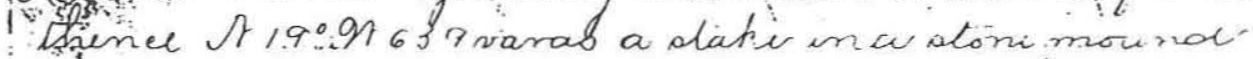

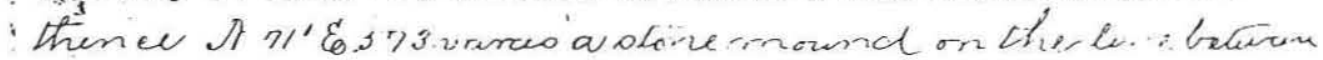

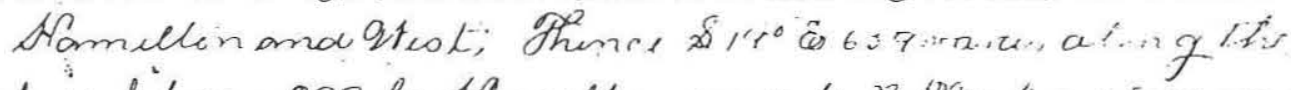

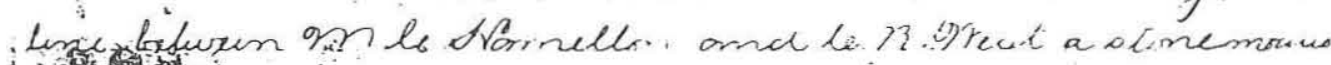

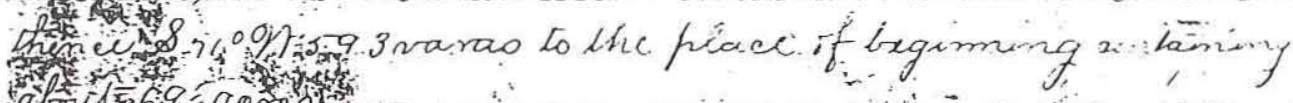

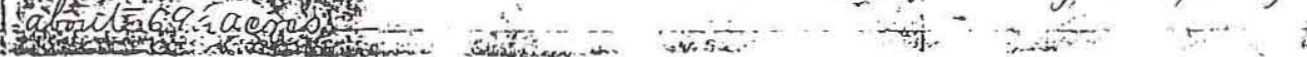

Figure 17. Plat and field notes of M. C. Hamilton's Subdivision of a portion of the Rachel Saul League. 
County land to Tyler, together with his interest in three other sizable tracts nearby (Deed Record 112:373-378). Tyler wasted no time in exploiting the natural resources along South Brushy Creek. In a move that would both provide immediate revenue and increase available pasture, Tyler signed a timber deed on November 18, 1905, with the Austin firm A. F. Martin \& Brother. Comprised of A. F. Martin and J. A. Martin of Austin, the cedar-cutting company was a corporate body that was active in Williamson County during the early twentieth century.

The deed signed by Tyler and A. F. Martin \& Brother was standard for the time. ${ }^{6}$ Tyler deeded "all the timber large enough for cord wood, that is; the timber three inches and over in diameter. ..." The timber was located on four tracts of land, one being near Rutledge Station, the second being west on the Austin and Burnet Road, the third being lot 13 and all of lot 10 west of the Houston and Texas Central Railroad, and the fourth being lot 12 and all of lots 11 and 5 lying west of the railroad. A. F. Martin \& Brother agreed to pay John Tyler $\$ 500.00$ in advance for the first thousand cords of wood and 50 cents per cord cut thereafter for a period of 3 years beginning December 31, 1905. The Martins received "free water and camping privileges for the wood choppers and haulers, and free pasturage for not exceeding eight horses or mules ..." (Deed Record 113:598-599).

Tyler also granted the Martins and their wood choppers and haulers "free ingress and egress" over his property as they supervised the work and transported the wood product "to Rutledge Station on the Houston \& Texas Central Railroad," successor to the Austin and Northwestern Railroad. Working together, Tyler and the Martins would agree on the locations of gates that would be installed in the fence line so that the wood could be loaded on the railroad easily (Deed Record 113:599-600).

Site 41WM892 suggests that the Martins

\footnotetext{
${ }^{6}$ The wording in the 1905 deed appears to be erroneous in two particulars. First, Tyler excepted the tracts from the deed, but then clearly stated that he was selling the "said timber, as above provided, on the tracts of land above described," i.e., the four tracts of land that he said were excluded. Second, he excluded the pecan and cedar, a clear misstatement since A. F. Martin \& Brother dealt in cedar products and their other, contemporaneous timber deeds in the area excluded pecan and oak.
}

fulfilled the terms of their contract with Tyler before moving on to their next business venture-development of the Austin White Lime Company with investor A. H. Robinson of Austin (Deed Record 124:612-613). Tyler sold the property, together with other tracts in the Damon Survey, 4 years after the Martins' contract lapsed (Deed Record 161: 293-296), and the land use remained predominantly agricultural.

\section{Assessment}

Site 41WM892 appears to be the location of a corporate-run wood-chopping camp that was active between 1905 and 1908. The camp was operated by Austin residents A. F. and J. A. Martin under the business name A. F. Martin \& Brother and is an example of a type of historic property that was once widely distributed throughout the Texas Hill Country during the late nineteenth and early twentieth centuries. Wood-chopping campsites were characterized by their large areal extent and paucity of artifacts. The sites were occupied for relatively brief periods of time by local and immigrant labor. Because of the volume of wood cut, such sites often were located near railroads; significantly, the Austin and Northwestern Railroad hauled large volumes of cedar from Llano County as well as Williamson County, serving the needs of entrepreneurs such as the Martin brothers and Malcolm Reed, businessmen who appear to have used cedar cutting as a springboard to other corporate enterprises.

While 41 WM892 is marginally interesting because it represents a commercial activity that once played a prominent role in the economy of the region, it does not appear to be eligible for listing in the National Register of Historic Places or for designation as a State Archeological Landmark. It is recommended that it be considered ineligible under National Register Criterion D because it lacks the ability to contribute important archeological information. The features are of low integrity and difficult to interpret with confidence, artifacts are scarce and of limited interpretive utility, and there is no potential for subsurface deposits with good integrity that could yield further information about structures, activities, or material culture associated with a cedar chopper camp. No amount of additional recording will make the function(s) of the rock alignments clearer, nor would collection of the artifacts exposed on the surface reveal anything that 
is not already obvious (i.e., the material culture of cedar choppers was dominated by utilitarian goods that were readily available, and they did not dispose of great amounts of trash).

National Register Criterion $\mathrm{C}$ requires that a site "embody the distinctive characteristics of a type, period, or method of construction, or that [it] represent the work of a master, or that [it] possess high artistic values, or that [it] represent a significant and distinguishable entity whose components may lack individual distinction" (National Park Service 1991:2). These requirements are most applicable to standing buildings or structures. Site 41WM892 does not contain buildings, and the structures present, i.e., the rock alignments presumably representing wall remnants, are not of sufficient integrity to convey "distinctive characteristics of a type, period, or method of construction." For this reason, the site does not appear to qualify for the National Register under Criterion C.

The potential significance of 41WM892 under National Register Criteria A and B centers on its association with corporate cedar chopping, an activity that was important to the local economy, and its association with A. F. and J. A. Martin, Austin businessmen who later developed the Austin White Lime Company. Additional historical research could be done to more fully explore these associations, for example to document the overall economic role of corporate cedar chopping in the first decade of the twentieth century, the relative importance of this site relative to other as-yet-unrecorded cedar chopping camps, and the importance of the Martins as local businessmen during the interval that 41WM892 was used. But an argument for conducting such additional research is not compelling given the low integrity of the physical remains at the site. As stated in National Register Bulletin 15 (National Park Service 1991:46), "Archeological sites eligible under Criteria A and B must be in overall good condition with excellent preservation of features, artifacts, and spatial relationships to the extent that these remains are able to convey important associations with events or persons." National Register Bulletin 32 (Boland 1991:25) further states that for a property to be significant under Criterion B, it must "retain integrity from the period of its significant historic associations." Given that many of the components that originally made up the cedar chopper camp at 41 WM892 are now gone (e.g., the habitations), that the remaining features are of uncertain function and thus limited interpretability, and that discernible distinctions between habitation areas and work areas have not survived, it would be difficult to argue that the site retains integrity from its period of use. Hence, it is recommended that the site be considered ineligible under Criteria A and B.

\section{Site 41 WM893}

\section{Site Description}

Site 41 WM893 is a remnant of the railroad spur constructed to facilitate work on Marshall Ford Dam (now Mansfield Dam) in the years 1937 to 1941. It originates at the southernmost point where the Leander Rehabilitation Center property line intersects the Southern Pacific Railroad. This is the area where construction materials would have been off-loaded from the main Southern Pacific line at Rutledge and on-loaded onto the spur for transport to Marshall Ford Dam. This loading area, called the "lay-down yard," was accommodated within an expanded right-of-way. The lay-down yard was constructed of poured concrete. After use of the spur was discontinued, the lay-down yard was dismantled, and large slabs of that concrete were discarded in the project area.

The middle section of the rail bed remains visible on the ground, whereas its berm on the southwestern and northeastern ends is not observable. The length of the surviving section is $475 \mathrm{~m}$. The 85 -m-long northeasternmost end of the surviving portion is a low sloping berm $11 \mathrm{~m}$ wide and $1.5 \mathrm{~m}$ high. The width and height remain consistent along the next $54 \mathrm{~m}$ to the southwest, but this segment is topped with angular rocks averaging in size from 10 to $20 \mathrm{~cm}$ along with smaller gravels (Figure 18). The rail bed then extends for another $336 \mathrm{~m}$ to the southwest as a berm without rocks or gravel. At the southwestern end of the visible remnant, the berm dissipates in a wooded area, and no other features or artifacts related to the railroad spur survive. Neither ties nor rails are in place. Most of the railroad remains are located within an area of tall native grasses and occasional trees.

\section{Site History}

Site 41 WM893 is located on lots 9,10 , and 14 of the Morgan C. Hamilton Subdivision of the 


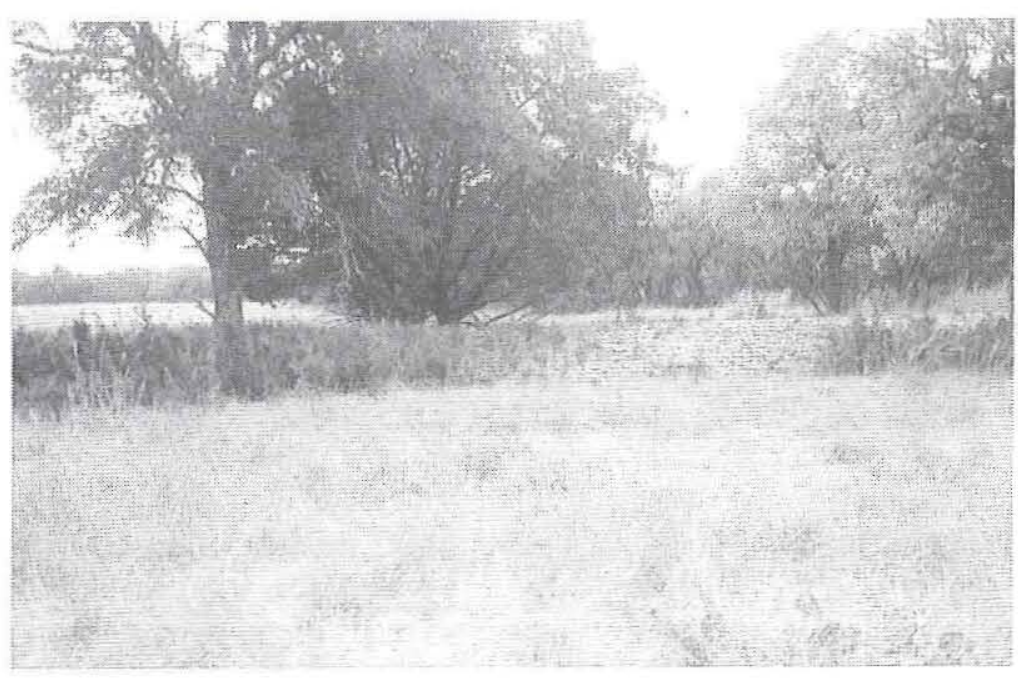

Figure 18. View south of railroad bed with exposed gravels, site 41WM893.

August 17, 1936. The Lower Colorado River Authority awarded a contract for construction on December 3 to the fledgling firm of Brown \& Root, Inc., in partnership with the McKenzie Construction Company of San Antonio (Banks and Babcock 1988:95).

Groundbreaking occurred on February 19, 1937, but construction was delayed when the U.S. Comptroller General's Office discovered that Congress had not authorized the project and the federal government did not own the dam site, prerequisites to the involvement of the Bureau of Reclamation which was to direct construction and furnish materials. Indeed, authori-

Rachel Saul League. The site runs diagonally across the lots from northeast to southwest and splits into a "V" before intersecting the old Austin and Northwestern Railroad bed a short distance south of the community of Rutledge.

The legal history of site 41 WM 893 is similar to that of site 41WM892 until March 29, 1937, when the Lower Colorado River Authority acquired 128 acres from the Montpelier Savings Bank and Trust Company. The property included the southernmost portion of the present-day project area, encompassing the portions of lots 9 and 14 lying south of the "most Northerly line of the Lower Colorado River Authority or Marshall Ford Dam railroad right of way. . . ." Another part of the legal description referred to "the proposed railroad right of way of the Lower Colorado River Authority," suggesting that the railroad had not been constructed by March 29, 1937, but that the Authority anticipated constructing a line from the Southern Pacific (formerly Austin and Northwestern) Railroad line to the future Marshall Ford Dam (Deed Record 283:549).

According to Banks and Babcock (1988:94), the Marshall Ford Dam was the "key flood control link" in the chain of dams comprised of Buchanan, Inks, Marshall Ford, and Austin and constructed by the Lower Colorado River Authority between 1935 and 1941. Marshall Ford, the third of the dams, was patterned after Grand Coulee Dam on the Columbia River and was located at a site selected by the Lower Colorado River Authority board on zation for funding did not occur until July 1937 following heavy lobbying in Washington, D.C., by a delegation comprised of Lower Colorado River Authority board members, counsel Alvin J. Wirtz, and Congressman Lyndon B. Johnson (Banks and Babcock 1988:95).

Construction of the Marshall Ford Dam, which was renamed Mansfield Dam in honor of U.S. Representative J. J. Mansfield, occurred between 1937 and 1941 when its 266.41-ft height and 7,098.39-ft length created a reservoir capacity of $1,170,752$ acre $\mathrm{ft}$. While the dam also was designed to store water and generate electricity, it was "the only structure in the Highland Lakes chain specifically designed to contain floodwaters" (Banks and Babcock 1988:232).

Specific records have not been located regarding site 41WM893 and its role in the construction of the Marshall Ford Dam. However, its identity in legal records, date of acquisition, and date of the sale of the 113.85 acres that surrounded the right-of-way by the Lower Colorado River Authority on April 12, 1945 , all suggest that the site was associated with the construction of the dam between 1937 and 1941 . Most likely, it was built by Brown \& Root. According to Scarbrough (1980:450), the "spur" was built from Rutledge on the main rail line to Mansfield Dam "to transport construction materials." Finally, the large slabs of broken concrete located in the "Y" adjacent to the main rail line are reminiscent of reinforced pads used as a lay-down yard for storing construction materials and equipment. 


\section{Assessment}

Site 41 WM893 is associated with the construction of the important Marshall Ford Dam, the "key flood control link" in what became known as the Highland Lakes chain. The Marshall Ford Dam Railroad probably was one of the first such construction projects of the then-fledgling firm of Brown \& Root, Inc., a company that has since become one of the largest construction companies in the world. The site appears to be the only portion of right-ofway that survives; the balance of the route parallels present-day FM 620. However, as an archeological site, 41WM893's lack of archeological deposits or other associated features means the site has fairly low integrity. Therefore, it is recommended that 41WM893 be considered not eligible for listing in the National Register of Historic Places or for designation as a State Archeological Landmark.

\section{Site 41WM896, Rhodes Farm}

\section{Description}

Site 41 WM896 is the remains of the Rhodes farm, which was occupied from 1937 to 1945 . It operated just previous to and in the initial years of the State Dairy and Hog Farm. It is located $1.1 \mathrm{~km}$ northeast of the U.S. 183 and FM 620 intersection. The site lies in an upland area that is partially wooded with junipers. Ground cover consists mostly of native grasses and clusters of prickly pear cactus. A tributary of Lake Creek is located ca. $400 \mathrm{~m}$ to the east. Soil deposition across the site area is generally shallow, and limestone bedrock is exposed in some places. As a result, shovel testing was not conducted.

Site 41 WM 896 is represented mostly by surface farm and household features (Figure 19). Portions of this facility continued to be used after the property was acquired for the State Dairy and Hog Farm, and additional livestock troughs moved to the area in the 1950s are not considered as part of the historic site. Also not part of the site is a modern dump area northwest of the former house location. Historic features include a circular stock tank, a sheep dip tank, a rectangular stock trough, a drilled well, a concrete platform, concrete piers, and a collapsed septic system. Further information on the Rhodes farm, its associated features, and photographs of the features are presented in the architectural resources section (Historic Resources Nos. 32b, 32c, and $32 \mathrm{e}$ ).

One older feature that was reportedly moved to the site is the circular stock tank (Wynn 1996). It is located at the easternmost end of the site, farthest

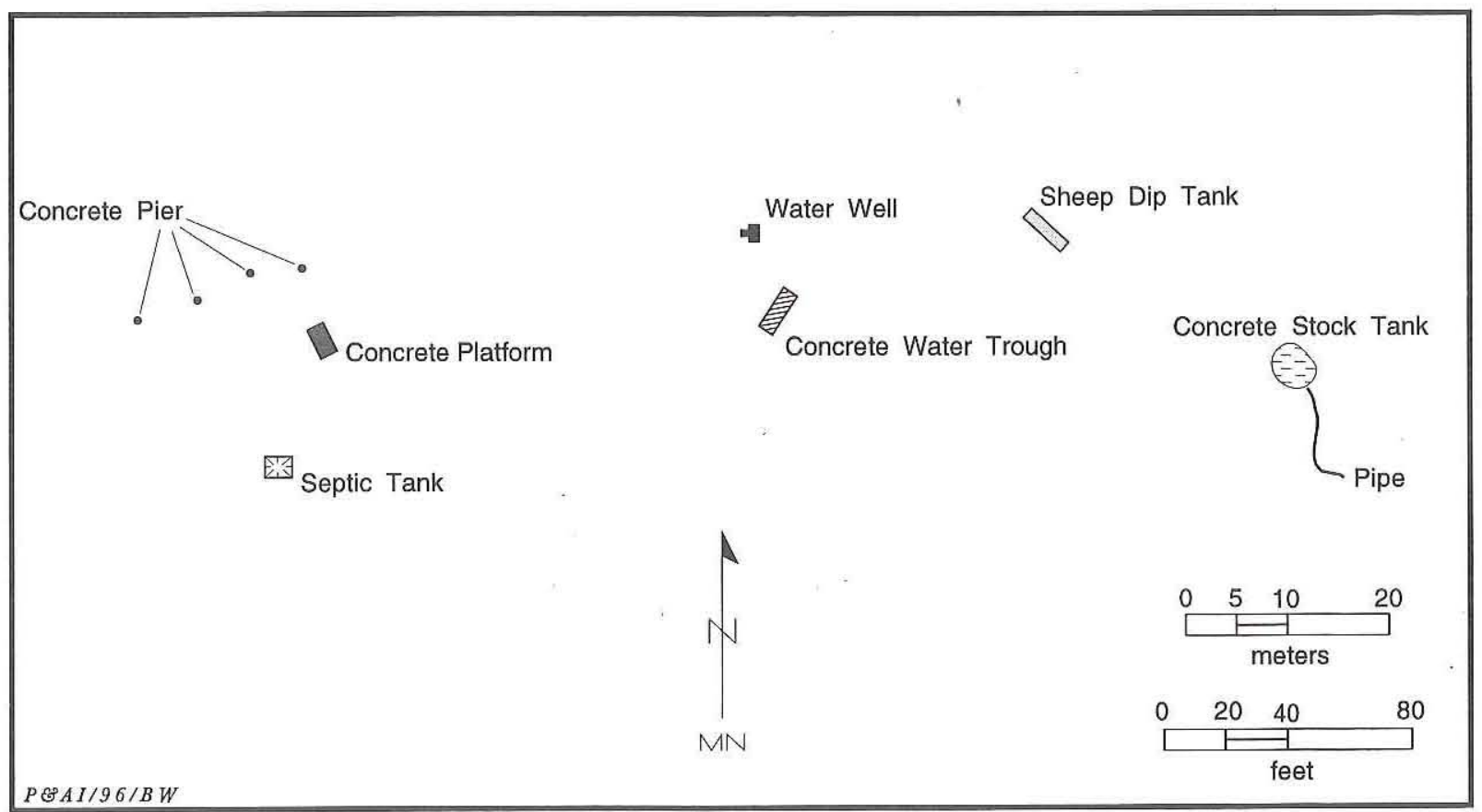

Figure 19. Map of site 41WM896, the Rhodes farm. 
away from the house area. The tank is constructed of poured concrete and is not perfectly circular. Its shape most closely resembles an irregular oval, with its north-south dimension being $2.54 \mathrm{~m}$ and its eastwest dimension being $1.98 \mathrm{~m}$. The walls of the stock tank are $0.39 \mathrm{~m}$ tall. A metal inlet pipe extends out of the southern side of the tank for ca. $10 \mathrm{~m}$. All the remaining farm and house features are definitely related to the Rhodes period occupation.

The next feature, ca. $23 \mathrm{~m}$ northwest of the circular stock tank, is a dipping tank for sheep. Dip tanks for livestock such as cattle, sheep, and pigs were designed to prevent the spread of splenetic fever by dipping the livestock in chemical baths to retard infestation by fever ticks. The tick eradication program was headed by the federal government beginning in 1906, and by 1945 all but the most southern counties of Texas along the border with Mexico had effectively been rid of the problem (Webb 1952:I:315-316).

This sheep dip tank is almost completely subterranean. It is rectangular in shape and is oriented northwest-southeast along its long axis. It measures $4.96 \mathrm{~m}$ long by $1 \mathrm{~m}$ wide. The dip tank is constructed of poured concrete, and corrugated tin roofing material was utilized as a form for the concrete, thus giving the walls of the tank a corrugated appearance. The dip tank has an entrance ramp on the northwestern end, which slopes down to the opposite end.

About $25 \mathrm{~m}$ west-southwest of the dip tank is another feature constructed by pouring concrete into corrugated tin forms. This feature is a rectangular stock trough. It is oriented northeast-southwest along its long axis. It measures $3.65 \mathrm{~m}$ long by $0.90 \mathrm{~m}$ wide, and its walls stand $0.58 \mathrm{~m}$ tall. These livestock and farming features cluster roughly together in an area removed from the house.

Centrally located within the site is the well. This position would have allowed it to supply water to both the house and the animals. It is a drilled wellhead with a pipe set into a poured concrete platform or cap. Informants describe this as "a shallow, 35-40-foot-deep well" (Wynn 1996). The well is located ca. $5 \mathrm{~m}$ northwest of the stock trough. The cap is rectangular in shape on its eastern half and semicircular on its western half. It is oriented northeast-southwest along its long axis, with maximum dimensions of $1 \times 2 \mathrm{~m}$.

The household component of the site lies ca.
$40 \mathrm{~m}$ southwest of the well. The house site consists of a poured concrete platform and four surviving concrete house piers. The concrete platform is rectangular in shape and is oriented northwestsoutheast along its long axis. It measures $2.50 \mathrm{~m}$ by $1.70 \mathrm{~m}$. This platform was the back porch.

Running in a roughly southwest-trending line $5 \mathrm{~m}$ north of the platform is a series of four piers. Most are not in situ, except for the westernmost pier which is still held in place with a large bolt. The piers are circular in shape.

This layout agrees well with the description of the house given by informants who lived in the house during the early days of the State Dairy and Hog farm (Wynn 1996). "It was a long rectangular house with a living room, dining room, and kitchen on one side, and three bedrooms on the right side." Wynn goes on to say,

At the house, you went up on the front porch. On the left was a living room with a stone fireplace on the wall, then there was an opening to the dining room, then you went through a single room to the kitchen. On the other side were three bedrooms. There was no hall, so each of the rooms on one side opened to the bedrooms on the opposite side. The front porch was covered, the back was not. The roof was gabled.

To the side and rear of the house (ca. $10 \mathrm{~m}$ south-southwest of the back porch) are the remains of the septic system. It consists of a collapsed area of ca. $3 \mathrm{~m}$ in diameter. There are exposed and broken, but still partially in situ, ceramic sewage pipes. There is also evidence of several efforts to cover over this exposed area with layers of wood and corrugated metal.

\section{Cultural Materials Observed and Collected}

The few artifacts observed on the surface at 41WM896 include clear bottle and jar glass (including a fragment of an embossed Dr. Pepper bottle), brown bottle glass, a tin can, and machinery parts. These few artifacts are consistent with a 1937 to 1945 occupation. It would appear that between the short period of domestic occupation and reuse of this area by the State Dairy and Hog Farm the vicinity was kept relatively free of sheet refuse. 


\section{Site History}

The T. W. Rhodes farmstead is located on lot 14 in the southeastern portion of the survey area in the Rachel Saul Survey, a one-league grant made to 1827 immigrant Rachel Saul of Jasper County. On October 5, 1837, Saul appointed Joseph M. Glasscock her attorney and requested that a deed to the league be made for Glasscock, who had paid Saul $\$ 500.00$. Possession of the property was vested in Glasscock on September 16, 1847, when he received a patent (General Land Office 1847).

On September 16, 1847, Glasscock sold the league to Morgan C. Hamilton, a resident of Austin, who subdivided much of it into lots (Deed Record 31:159-160). He sold a number of the lots and then conveyed the balance (lots 3, 5, 6, 9, 10, 13, and 14) to his nephew, Robert A. Smith, of Travis County on May 7, 1883 (Deed Record 31:159-160). Smith sold those lots to Dr. C. Q. Graves of Travis County of March 24, 1884 (Deed Record 34:130 131), who conveyed a total of eight lots to Mrs. L. A. Graves of Boone County, Kentucky, on November 21, 1894 (Deed Record 77:42-43). Mrs. Graves then sold four lots $(9,10,13$, and 14) to Effie Graves of Travis County on November 30, 1898 (Deed Record 87:200-201), who conveyed them to W. E. Armstrong and John Tyler in about 1904 (Deed Record 111:339-342).

The same year, Armstrong sold his half-interest in his Williamson County property to John Tyler (Deed Record 112:373-377), who held it until 1912 when he sold eight tracts of land in the Damon and Saul Surveys to J. T. and W. B. Sites of Caldwell County (Deed Record 161:293-296). W. B. Sites then sold out his interests to J. T. Sites in 1914 (Deed Record 161:400-402). Subsequent owners of lot 14 and the surrounding property were R. L. Bewley (1916); Van M. Smith, an Austin druggist (1916); and O. L. Koock (1918), an Austin hardware dealer whose extensive ranch headquarters was located on lot 14 northeast of site 41WM896 (Deed Record 177:106-107; 181:28-29; 183:604-606; 185:553-554; Wynn 1996).

In 1935 , the Koocks lost their ranch to the Montpelier Savings Bank and Trust (Deed Record 276:115), which sold 339 acres of the ranch in lots 9-14 to T. W. and Hattie Rhodes of Williamson County on November 4, 1937 (Deed Record 288: 459). T. W. Rhodes (1877-1966), a native of Lavaca County who moved to Williamson County and became a farmer (The Williamson County Sun, April 28, 1966:2), appears to have constructed a highly improved farmstead at 41WM896. According to records kept by the State Board of Control, the farmstead included a residence, outdoor toilet, log smokehouse, railroad tie smokehouse, log feed barn, sheep and goat shed, milking cow shed, log grain and hay crib, truck and tractor garage, brooder house for chickens, and pole frame chicken house (State Board of Control, Box 1991/16-85).

On August 27, 1945, after extensive negotiations, the Rhodeses sold their 339-acre farm to the State Board of Control (Deed Record 328:548549). Soon thereafter, Mr. and Mrs. Leonard Wynn moved into the Rhodes house as manager of the Rhodes farm division of the State Dairy and Hog Farm. The following year, the Wynns moved into a brick cottage at the headquarters area (Wynn 1996). Most components of the Rhodes farm were destroyed at an unidentified date.

\section{Assessment}

Site 41WM896, the Rhodes farm, represents the only recognizable farmstead that survives from the period before the State Dairy and Hog Farm. Other farmsteads that existed within the project area, such as the Dedear farm or the Koock farm, have been destroyed and nothing of them remains archeologically. The site has remnants of several of the major farmstead structures. However, many other farmstead features that were reported to have once been there are now gone, such as the log barn, the chicken house, the galvanized water tank, and the peach orchard (Wynn 1996). This farmstead is also unusual in that it does not have much in the way of surface artifact scatters. Due to its late historic date (1937-1945), its lack of potential to yield archeological data, and the amount of information available via other data sets (i.e., archival and informant data), it is recommended that 41 WM 896 be considered not eligible for listing in the National Register of Historic Places or for designation as a State Archeological Landmark.

\section{Site 41 WM897}

\section{Description}

Site 41WM897 consists of a single feature, a 
hand-dug well. The well sits on the crest of a small hill and is "actually a spring that was converted into a well" (Wynn 1996). The well sits in an open grassy area with an area of juniper woods to the west. The spring feeds a tributary to Buttercup Creek. Soil deposition at the site area is fairly shallow (ca. 8-10 cm) and rocky. No surface artifacts were observed in the immediate vicinity of the well, and random shovel probes yielded no artifacts.

The well has a new modern superstructure. According to Wynn (1996), "the Rehabilitation people put the rock around the well." The superstructure is square, measures ca. $1.20 \mathrm{~m}$ on a side, and stands to a height of ca. $90 \mathrm{~cm}$. Construction materials consist of mortared cut limestone topped with a gabled roof on two poles, all constructed of juniper. The well opening is round with an $80-90-\mathrm{cm}$ average diameter. It is lined with very roughly cut or natural limestone slabs. Approximately $84 \mathrm{~cm}$ of limestone lining is visible from the ground surface until visibility is obscured by refuse fill and standing water within the well.

\section{Cultural Materials Observed and Collected}

Almost no artifacts were observed associated with the well or in the area in general. The one exception is a single undecorated whiteware rim sherd found on the surface across the creek in an open field to the northeast. There is no way to know if this nondiagnostic sherd is associated with the well.

\section{Site History}

Site 41 WM897 is located in the westernmost portion of the survey area on the Samuel Damon league, a tract of land on Brushy Creek that was patented to Damon on November 29, 1847 (General Land Office 1847). Several months later, on January 22, 1848, Damon, who lived in Brazoria County, sold half of his league to Thomas Dillard of Burleson County (Deed Record 7:476), who held the property until his death. A deed dated January 18 , 1867 , suggests that his property then was partitioned and that Absalom and Poleman G. Dillard received the portion of the league on which 41WM897 was located (Deed Record 10:291-292). Absalom conveyed his portion to Sandy Shoemaker who, with
Poleman, sold the property to Robert Hannah on January 18, 1867 (Deed Record 10:291-292).

Hannah owned the property for a year before selling it to M. C. Baird (Deed Record 10:417-418). Subsequent owners included Joseph B. Long (1869-1871), Evan Phelan (1871), and John P. Dodd, who purchased land in the Damon League in 1871 and, 5 years later, purchased an additional 58.59 acres in the Damon League and 621.5 acres in the adjoining Rachel Saul League from Samuel P. Mayo. Dodd and his family probably lived a short distance northwest of the project area in Buttercup, where they owned and operated a large mill complex (Deed Record 11:447-448; 13:360-361; 17:532-533; 21:220-221).

Sometime after 1876, John P. Dodd deserted his wife and children. By 1889, Mrs. Dodd decided to sell the approximately 798 acres on Brushy Creek in the Saul and Damon Surveys to R. W. Dodd of Lavaca County (Deed Record 52:30-33). R. W. Dodd then conveyed the land to his wife, Rosa, on July 6, 1896 (Deed Record 78:173-175), and she and other family members who had an interest in the property sold it to W. E. Armstrong of Travis County (Deed Record 91:386-389). The Armstrongs then sold the land, and additional acreage in the Rachel Saul League to the east, to John Tyler between 1901 and 1904 (Deed Record 92:631-634; 112:373-377).

By 1912, John and Fannie Tyler of Williamson County owned more than 1,200 acres in and near the project area. At that point, they sold out to W. B. Sites of Caldwell County (Deed Record 161: 293-296). Later owners included J. T. Sites (1914-1919), Paul Koenig (1919-1928), Roy C. Archer, a judge in Austin (1928), and O. L. Koock of Austin, who owned the adjoining property (1928-1935) (Deed Record 161:400-402; 192:332334; 237:391; 415-416).

In 1935, the Koocks lost the western portion of their property to the Federal Land Bank of Houston (Deed Record 276:448-451). The bank then sold the acreage on which 41 WM897 is located to N. J. Dedear on May 29, 1936 (Deed Record 280:251254). The Dedears evidently intended to occupy the property, for in 1937 the arranged a mortgage in order to purchase "materials and labor for the erection of a dwelling-house and improvements ..." (Deed of Trust Record 66:219). An aerial photograph indicates that the Dedear home and farmstead were located in the vicinity of the present-day State 
Dairy and Hog Farm administrative and residential facility. A description of the farmstead listed improvements that included a six-room house with a sheet iron roof ("recently rebuilt out of second hand lumber . . ."), a sheep shed, a grain bin, a water well, and a surface tank on the creek located north of the Dedear house in the vicinity of 41WM897 (State Board of Control, Box 1991/16-9).

The Dedears sold their farm to the State Board of Control on June 2, 1942, but were given permission to occupy the property until July 4 due to an illness in the family (Deed Record 311:551-554; State Board of Control, Box 1991/16-44). According to Wynn (1996), the Dedear house remained at the headquarters area for several decades after their farm was acquired by the state.

\section{Assessment}

Site 41 WM897 is a single well. It appears to have been a remote, expedient (it uses an existing natural spring) water source location associated with the Dedears or one of the previous owners of the land. The lack of any surviving archeological component means that this site has little potential to yield information important to the history of the project area, and it is recommended that the site be considered not eligible for listing in the National Register of Historic Places or for designation as a State Archeological Landmark.

\section{BUILDINGS AND STRUCTURES}

Rural in character, the survey area contains two distinct concentrations of pre-1952 buildings and structures associated with three major development periods (Figure 20). The first concentration is located near the entrance to the facility on U.S. Highway 183 and includes administrative and residential buildings as well as agricultural resources associated with the dairy operations of the farm. The second grouping of extant pre-1952 resources is southeast of the administrative/residential/dairying area on the site of the former Rhodes farmstead. This area includes a wood-frame house and a number of scattered feed and water troughs associated with the agricultural uses of the property. Nearby are two pole barns, assorted feed and water troughs, and fencing remnants associated with hograising activities between 1946 and 1951. A third developed area consists of a row of pole barns that were originally part of the hog-raising activities and subsequently converted to dormitory use by the Leander Rehabilitation Center. This area was originally thought to have been part of hog-raising operations in the late 1940s and early 1950s. Information supplied subsequent to the field documentation by Leonard Wynn, storekeeper/accountant and then business manager for the State Dairy and Hog Farm from 1945 to 1969 , revealed that the barn/dormitory buildings were constructed about 1955. They are included in this report because they were documented, but they are outside the scope of work.

\section{Historic Resource No. 1, Storekeeper/Accountant's Office and Warehouse}

Building No.: $600 / 8120$

Function: Storekeeper/accountant's office and warehouse

Construction Date: 1943

Description: This one-story, rectangular-plan, yellow brick building (Figure 21) includes space for an office and a warehouse. Resting on a concrete slab foundation, the building has a side-gabled standing-seam metal roof and overhanging eaves with exposed rafter tails and knee braces. Although a compact building, the general effect of the massing is reminiscent of the horizontality typically associated with Ranch-style architecture. The building utilizes interior and exterior brick walls separated by a narrow air space for insulation. This building method is known as cavity-wall construction. The yellow bricks used in this building are nearly identical to those seen on the other brick buildings at the facility, but slight variations of color and texture suggest that the bricks used here came from a different source or from a different batch, or may be slightly older. The primary elevation faces west and is sheltered by an attached, full-width, shed-roof porch supported on square wood posts. Entry to the office is through a five-panel wood door at the northwest corner of the building. Warehouse entry is through hinged double wood doors on the north elevation. Most of the regularly spaced windows, which were originally wood-frame casement with horizontal lights, have been replaced with hinged plywood within the original openings. The original casement windows are similar in form and materials to those seen in buildings designed by the National 


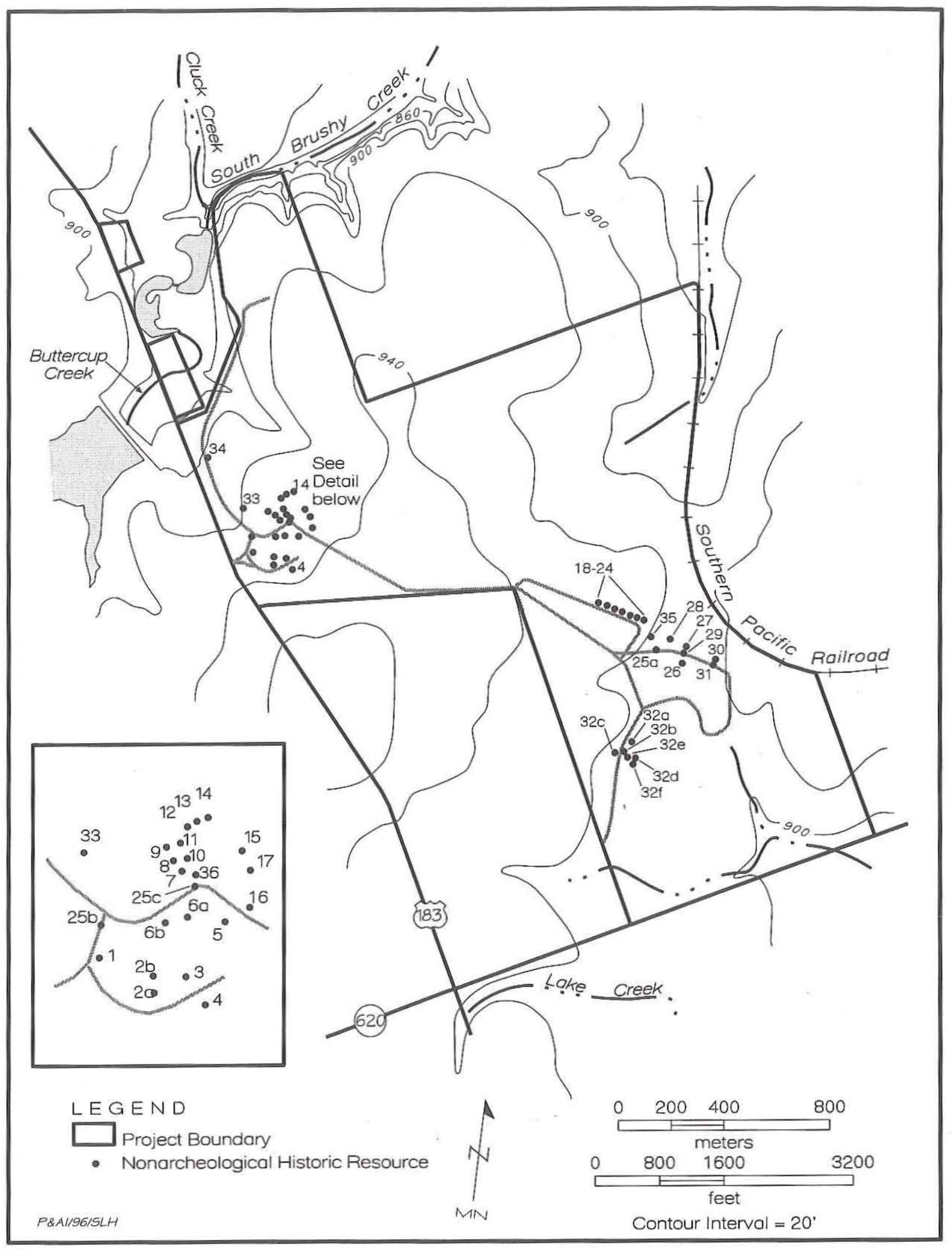

Figure 20. Locations of historic resources. 


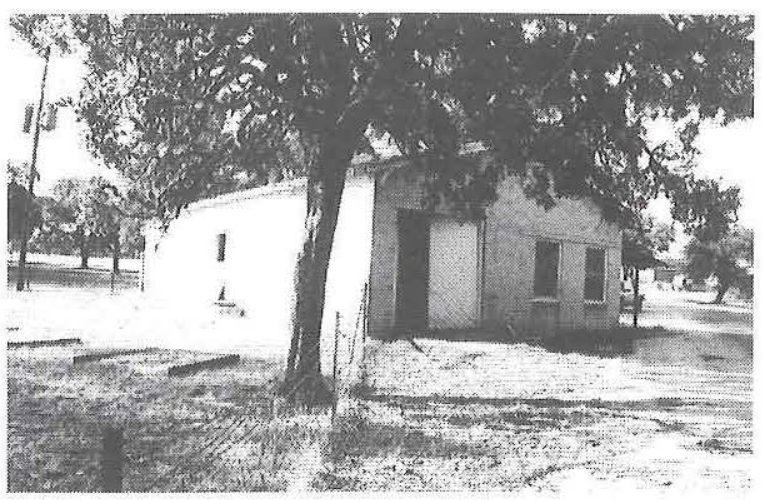

Figure 21. View to the southeast of Historic Resource No. 1, storekeeper/accountant's office and warehouse.

Park Service in the 1930s. One window in the office area of the building is a double-hung woodsash type with $8 / 8$ lights. The windows have brick sills and are placed just below a one-brick-wide string course. All interior walls are exposed brick, with the exception of the office partitions, which are constructed of a variety of sheetrock and plywood. The ceiling is open to the roof, exposing a wood truss system. Alterations appear confined to the replacement of the original windows with plywood within the original window openings, enclosure with chicken wire of a small portion of the southwest corner of the front porch, and changes to the interior partition walls. Despite these changes, the building retains its ability to convey a strong sense of time and place and has a moderately high degree of integrity.

Historical Background: Located near the entrance to the Dairy and Hog Farm, this building served as the headquarters for the facility. Administrative decisions were made there, and the warehouse provided storage for supplies. The office-warehouse is one of the six original permanent buildings and structures erected during the first phase of construction (Historic Resources Nos. 1, 2a, 3, 4, 33, and 34). The design of this building, the other four brick resources, and the concrete septic (Imhoff) tank are attributed to Walter C. Moore, Jr., an architect in the employ of the State Board of Control, which had jurisdiction over the facility and its programs by 1943 . Built during World War II, the office-warehouse was constructed by crews from the Austin State Hospital.

The use of cavity-wall construction, common in institutional and commercial buildings, may be atypical for small-scale buildings. Nonetheless, it was highly appropriate given that the technology reduces condensation, thus minimizing the transfer of humidity. Thought to have been built during World War II when metal and wood were scarce and, if available, quite expensive, the use of brick suggests that it may have been an affordable material available locally. Stylistically, the building also is atypical in that it combines an early appearance of Ranch-style domestic design with decorative features from the older Craftsman tradition. The horizontal form of the building is characteristic of Ranch-style architecture, which became the national residential style of choice in the post-World War II era. The wood knee braces, located under the eaves, reference the aesthetic associated with the Craftsman style popular nationally between 1905 and 1930. The somewhat unusual technological and aesthetic features of this building suggest that its designer was an able, innovative practitioner who appropriately modified standard construction methods and visual forms to create specialized facilities from limited materials.

Assessment: The office-warehouse is 1 of the 6 original permanent buildings and structures built at the farm and 1 of 21 buildings and structures associated with the initial use and development of the State Dairy and Hog Farm between 1942 and 1951. It contributes to an understanding of the mission of the facility during that period. It is significant for its role as the administration building at the farm and for its association with the first phase of construction. The use of cavity-wall construction and the melding of Ranch-style and Craftsman-style design features suggest architectural significance as well. Although the alterations to the windows and the enclosure of a portion of the porch have diminished its integrity somewhat, it retains sufficient original form and materials to be recognizable to its date of construction. For these reasons, it is recommended that the office-warehouse be considered eligible for listing in the National Register of Historic Places under Criteria $\mathrm{A}$ and $\mathrm{C}$ as a Contributing property within the State Dairy and Hog Farm Administrative, Residential, and Dairy Operations Historic District and for designation as a State Archeological Landmark.

\section{Historic Resource No. 2a, Superintendent's House}

Building No.: ?/8127

Function: Superintendent's house 
Construction Date: 1946

Description: This one-story, rectangular-plan, yellow brick dwelling (Figure 22) rests on what appears to be a pier-and-beam foundation enclosed by a concrete sill. Decorative brick vents provide crawlspace ventilation. The house faces south, has a partial-width integral porch at the southwest end, and is sheltered by a side-gabled standing-seam metal roof pierced by a brick chimney. Board-andbatten siding in the gable ends, exposed rafter tails, and knee braces enhance the building. Three concrete and gravel hog feed troughs are at the front of the house. Moved from elsewhere within the facility, they served as flower planters. At the rear of the house is a small attached porch addition with wide shiplap siding and $6 / 6$ wood-frame double-hung sash windows. The building is compact, but the general effect of the massing is reminiscent of the horizontality typically associated with Ranch-style architecture. The building utilizes interior and exterior brick walls separated by a narrow air space for insulation. Entry to the house is through the wood panel door with four fixed lights. The original double-hung wood-sash $2 / 2$ windows with brick sills remain in place. All interior walls were originally exposed brick. Most are now covered with drywall. A red brick fireplace surround is the focal point of the living room. The house retains a high degree of architectural integrity with the only apparent modifications being the addition of the rear porch, replacement of the original roof material (which was probably composition shingle), and the installation of drywall over the interior brick walls. Associated with the house is a detached one-story wood-frame garage (Historic Resource No. 2b).

Historical Background: Located south of the entrance to the Dairy and Hog Farm, this building is the first and largest of three brick residences clustered along a secondary road within the facility. The dwelling served as a residence for the superintendent, or primary administrator, of the facility and is one of the six original permanent buildings and structures erected between 1943 and 1946 (Historic Resources Nos. 1, 2a, 3, 4, 33, and 34). Internal correspondence of the State Board of Control dated December 3, 1945, records the completion of construction plans for this building (State Board of Control, Box 1991/16-65). The design of this building and the other five original resources are attributed to Walter C. Moore, Jr. Like the other four original brick buildings, it is of cavity-wall construction and is stylistically atypical in that it

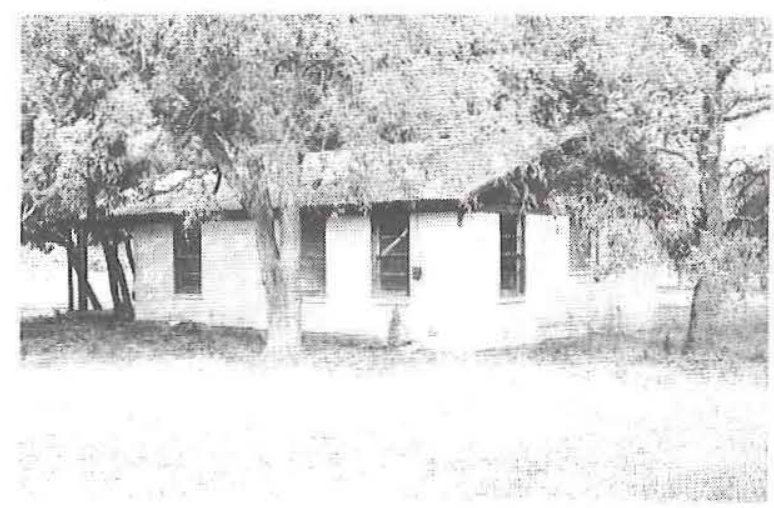

Figure 22. View to the northwest of Historic Resource No. 2a, Superintendent's house.

combines an early appearance of Ranch-style domestic design (i.e., the horizontal form of the building and the use of wood siding in the gable ends) with decorative features from the older Craftsman tradition (i.e., the wood knee braces located under the eaves and the exposed rafter tails).

Assessment: This house is 1 of the 6 original permanent buildings and structures built at the farm and 1 of 21 buildings and structures associated with the early phases of use and development of the State Dairy and Hog Farm between 1942 and 1951. It contributes to an understanding of the mission of the facility during that period. It is significant for its association with the residential aspect of the farm and for its association with the first phase of construction. The use of cavity-wall construction and the melding of Ranch-style and Craftsman-style design features suggest architectural significance as well. While the interior alterations to the walls have obscured the original interior finishes, these modifications are cosmetic and the cavity wall construction remains intact; the house is otherwise unaltered. It conveys a strong sense of time and place and is recognizable to its date of construction. For these reasons, it is recommended that this house be considered eligible for listing in the National Register of Historic Places under Criteria $\mathrm{A}$ and $\mathrm{C}$ as a Contributing property within the State Dairy and Hog Farm Administrative, Residential, and Dairy Operations Historic District and for designation as a State Archeological Landmark.

\section{Historic Resource No. 2b, Superintendent's Garage}

Building No.: 618/? 
Function: Superintendent's garage

Construction Date: 1946

Description: This one-story, rectangular-plan, wood-frame, wood-sided, three-bay garage (Figure 23) has a side-gabled standing-seam metal roof, exposed rafter tails, board-and-batten siding, and an earthen floor. None of the three bays have doors. The detached garage faces west and is located directly behind the house with which it is associated (Historic Resource No. 2a). Alterations include the addition of a small metal-sided storage room on the south elevation and the replacement of one of the original wood posts in the bay area with a metal Lally column. The roof is thought to be a replacement for original composition shingle roofing. The garage retains a moderate degree of integrity.

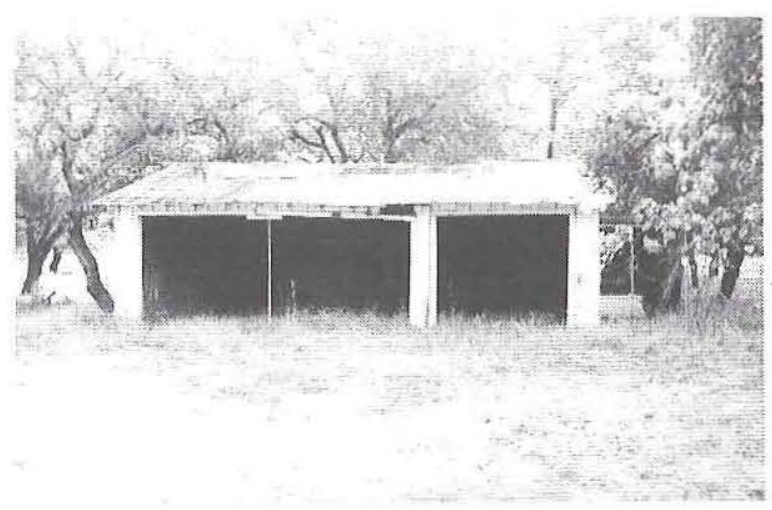

Figure 23. View to the east of Historic Resource No. 2b, Superintendent's garage.

Historical Background: This building served an auxiliary function as a garage for the superintendent, or primary administrator, of the facility. The garage is thought to have been built, probably from salvaged lumber, as part of the first phase of construction. The designer of the building is unknown. It may have been planned by Walter C. Moore, Jr. Moore, who designed the brick buildings, is thought to have prepared plans for the Imhoff tank as well. It is also possible, even likely, that the garage was built without plans.

Assessment: The garage is associated with the superintendent's house and contributes to an understanding of the uses and development of the State Dairy and Hog Farm in the 1942-1951 period. One of 21 buildings and structures associated with the initial use and development of the farm, it contributes to an understanding of the mission of the facility during that period. It is significant for its association with the residential aspect of the farm and for its association with the first phase of construction. The garage retains a moderate degree of integrity and is recognizable to its date of construction. For these reasons, it is recommended that this garage be considered eligible for listing in the National Register of Historic Places under Criterion A as a Contributing property within the State Dairy and Hog Farm Administrative, Residential, and Dairy Operations Historic District and for designation as a State Archeological Landmark.

\section{Historic Resource No. 3, Storekeeper/Accountant's Residence}

\section{Building No.: $626 / 8128$}

Function: Storekeeper/accountant's residence Construction Date: 1945

Description: This one-story, rectangular-plan, yellow brick dwelling (Figure 24) rests on what appears to be a pier-and-beam foundation enclosed by a concrete sill. Decorative brick vents provide crawlspace ventilation. The house faces south and has an asymmetrical facade with a partial-width, shed-roof attached porch supported on square posts. The house is sheltered by a side-gabled standingseam metal roof. Board-and-batten siding in the gable ends, exposed rafter tails, and knee braces enhance the building. Although a compact onebedroom house, the general effect of the massing is reminiscent of the horizontality typically associated with Ranch-style architecture. The building utilizes interior and exterior brick walls separated by a narrow air space for insulation. Entry to the house is through the wood panel door with four fixed lights. The original double-hung wood-sash $2 / 2$ windows with brick sills remain in place. All interior walls were originally exposed brick. Most are now covered with drywall. The house retains a high degree of architectural integrity with the only apparent modifications being the replacement of the original roof material, which was probably composition shingle, and the installation of drywall over the interior brick walls.

Historical Background: Located south of the entrance to the Dairy and Hog Farm just east of the superintendent's residence, this building served as a residence for the storekeeper/accountant of the facility. The house is one of the six original permanent buildings and structures erected between 1943 


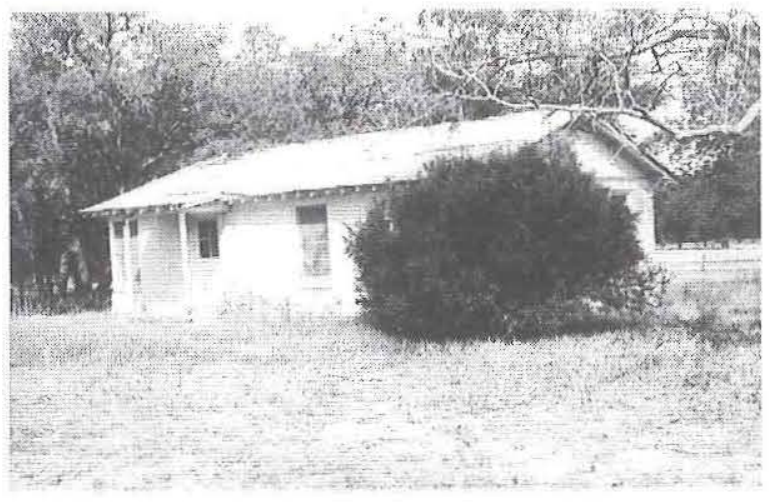

Figure 24. View to the northwest of Historic Resource No. 3, storekeeper/accountant's residence.

and 1946 (Historic Resources Nos. 1, 2a, 3, 4, 33, and 34). The design of this building and the other five permanent resources are attributed to Walter $\mathrm{C}$. Moore, Jr. Like the other four original brick buildings, it is of cavity-wall construction and is stylistically atypical in that it combines an early appearance of Ranch-style domestic design (i.e., the horizontal form of the building and the use of wood siding in the gable ends) with decorative features from the older Craftsman tradition (i.e., the wood knee braces located under the eaves and the exposed rafter tails).

Assessment: This house is 1 of the 6 original permanent buildings and structures built at the farm and 1 of 21 buildings and structures associated with the initial use and development of the State Dairy and Hog Farm between 1942 and 1951. It contributes to an understanding of the mission of the facility during that period. It is significant for its association with the residential aspect of the farm and for its association with the first phase of construction. The use of cavity-wall construction and the melding of Ranch-style and Craftsman-style design features suggest architectural significance as well. While the interior alterations to the walls have obscured the original interior finishes, these modifications are cosmetic and the cavity wall construction remains intact; the house is otherwise unaltered. It conveys a strong sense of time and place and is recognizable to its date of construction. For these reasons, it is recommended that this house be considered eligible for listing in the National Register of Historic Places under Criteria $\mathrm{A}$ and $\mathrm{C}$ as a Contributing property within the State Dairy and Hog Farm Administrative, Residential, and Dairy Operations Historic District and for designation as a
State Archeological Landmark.

\section{Historic Resource No. 4, Dairyman's Residence}

Building No.: $627 / 8129$

Function: Dairyman's Residence

Construction Dates: 1943, 1965

Description: This one-story, rectangular-plan, yellow brick dwelling (Figure 25) rests on what appears to be a pier-and-beam foundation enclosed by a concrete sill. Decorative brick vents provide crawlspace ventilation. The house faces north and has an asymmetrical facade with a partial-width, shed-roof, attached porch supported on square posts. The house is sheltered by a side-gabled standingseam metal roof. Board-and-batten siding in the gable ends, exposed rafter tails, and knee braces enhance the building. Although a compact onebedroom house, the general effect of the massing is reminiscent of the horizontality typically associated with Ranch-style architecture. The building utilizes interior and exterior brick walls separated by a narrow air space for insulation. Entry to the house is through the wood panel door with four fixed lights. The original double-hung wood-sash $2 / 2$ windows with brick sills remain in place. All interior walls were originally exposed brick. Most are now covered with drywall. Alterations include a side-gabled wood-frame room addition and a shedroof carport on the east end of the house. While these alterations are sensitive to the overall massing of the house, their prominent placement on the main elevation has altered the original scale of the building. The use of shiplap siding on the addition is incompatible with the original brick construction.

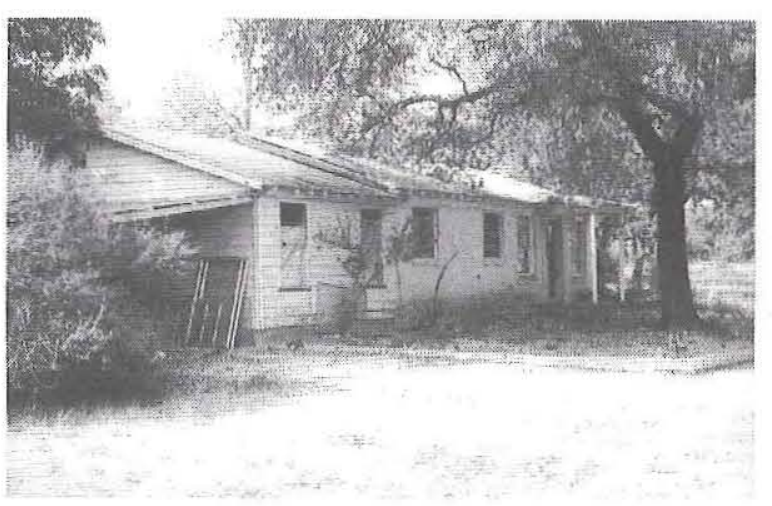

Figure 25. View to the southwest of Historic Resource No. 4, dairyman's residence. 
Because of these changes, the house retains a moderately low degree of architectural integrity.

Historical Background: Located south of the entrance to the Dairy and Hog Farm, this building served as a residence for the dairyman of the facility. The house is one of the six original permanent buildings and structures erected between 1943 and 1946 (Historic Resources Nos. 1, 2a, 3, 4, 33, and 34). The design of this building and the other five permanent resources are attributed to Walter C. Moore, Jr. Like the other four original brick buildings, it is of cavity-wall construction and is stylistically atypical in that it combines an early appearance of Ranch-style domestic design (i.e., the horizontal form of the building and the use of wood siding in the gable ends) with decorative features from the older Craftsman tradition (i.e., the wood knee braces located under the eaves and the exposed rafter tails).

Assessment: This house is 1 of the 6 original permanent buildings and structures built at the farm and 1 of 21 buildings and structures associated with the initial use and development of the State Dairy and Hog Farm between 1942 and 1951. It contributes to an understanding of the mission of the facility during that period. It is significant for its association with the residential aspect of the farm and for its association with the first phase of construction. The use of cavity-wall construction and the melding of Ranch-style and Craftsman-style design features suggest architectural significance as well. Although exterior additions have changed the scale of the dwelling, the original portion of it appears unaltered. While the interior alterations to the walls have obscured the original interior finishes, these modifications are cosmetic and the cavity-wall construction remains intact. The house is recognizable to its date of construction. For these reasons, it is recommended that this house be considered eligible for listing in the National Register of Historic Places under Criteria A and C as a Contributing property within the State Dairy and Hog Farm Administrative, Residential, and Dairy Operations Historic District and for designation as a State Archeological Landmark.

\section{Historic Resource No. 5, Maintenance Barn}

Building No.: ?

Function: Maintenance barn
Construction Date: ca. 1950

Description: This one-story, wood-frame, rectangular-plan barn (Figure 26) faces west and is covered by a front-gabled corrugated metal roof pierced by three projecting metal vents. The exterior walls are clad in corrugated metal. A large nonoriginal exhaust fan is mounted on the east endwall, which also contains two four-light fixedpane transoms in the gable end. Along the south elevation are five equidistant above-grade openings with corrugated metal doors. Just below the shallow eaves is a row of four-light fixed-pane transom windows. A sliding barn door is located in the west wall. Inside, the barn has a concrete slab floor and a wood truss roof structure. Assembled from a salvaged barn originally located at the National Youth Administration Camp at Inks Lake, alterations to this building include the installation of the exterior exhaust fan and the construction of the concrete slab floor. Although changes to the barn are minimal, it is somewhat deteriorated and in only fair condition. It retains a moderate amount of architectural integrity.

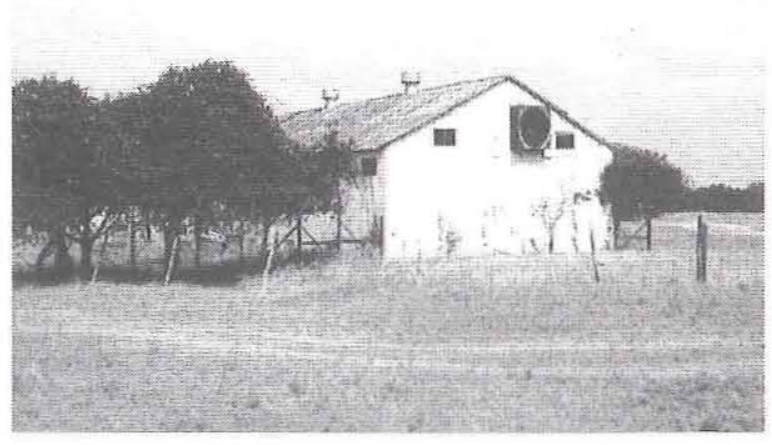

Figure 26. View to the southwest of Historic Resource No. 5, maintenance barn.

Historical Background: Located east of the entrance to the Dairy and Hog Farm in the dairy operations area of the facility, this barn was used as a maintenance building. Reassembled from salvaged materials, this building is part of the abundant government surplus materials acquired by the farm in the years after World War II. The barn served the farm during the first phase of its operations when it supplied both dairy and pork products to Austin's eleemosynary institutions.

Assessment: This barn is associated with the 
mission of the farm between 1942 and 1951 and contributes to an understanding of the uses and development of the State Dairy and Hog Farm in that period. One of 21 buildings and structures associated with this phase of use of the facility, it is significant for the secondary role it played in the operations of the farm. The barn retains a moderate degree of integrity and is recognizable to its date of construction. For these reasons, it is recommended that this barn be considered eligible for listing in the National Register of Historic Places under Criterion $\mathrm{A}$ as a Contributing property within the State Dairy and Hog Farm Administrative, Residential, and Dairy Operations Historic District and for designation as a State Archeological Landmark.

\section{Historic Resource No. 6a, Hay Barn and Implement Shed}

Building No.: ?/8135

Function: Hay barn and implement shed

Construction Date: ca. 1955

Description: This one-story, wood-frame, rectangular-plan hay barn (rear portion) and implement shed (front portion) is constructed of two sections of differing heights (Figure 27). The barn and implement shed face west; both sections are covered by a front-gabled corrugated metal roof. Shallow overhanging eaves have exposed rafter tails. The exterior walls are clad in corrugated metal, and barn door openings along the north and south elevations have hinged, wood-frame, corrugated metal-clad doors. One door on the north side has a wood sign imprinted with the word "ambulance." Inside, the implement shed has an earthen floor. The roof is supported by a wood-frame structural system. The rear barn area has a nonoriginal concrete slab floor. The roof support for the barn area is not visible due to the barn's current use for storage. There are no apparent alterations to this building. It retains a moderate degree of architectural integrity due to lack of maintenance.

Historical Background: Located east of the entrance to the Dairy and Hog Farm in the dairy operations area of the facility, this building was used as a hay storage barn and an implement shed during the second phase of operations at the farm. At various times, the barn also was used to house the facility's fireifighting equipment and an ambulance.

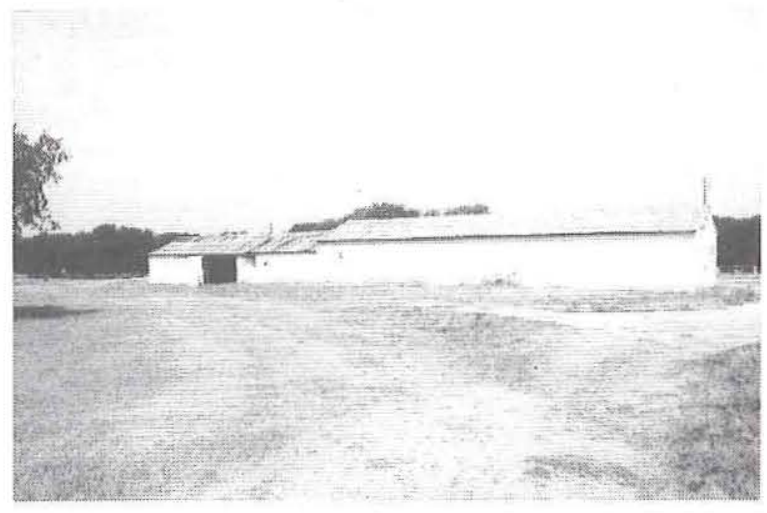

Figure 27. View to the southwest of Historic Resource No. 6a, hay barn and implement shed.

Assessment: Because this barn is not yet 50 years of age, is not associated with the first phase of operations at the farm, and is not exceptional or rare, it is recommended that it be considered not eligible for listing in the National Register of Historic Places or for designation as a State Archeological Landmark.

Historic Resource No. 6b, Truck Scale

\section{Building No.: ?}

Function: Truck scale

Construction Date: ca. 1955

Description: This truck scale is comprised of a one-story side-gabled shed and an in-ground scale (Figure 28). The shed has corrugated metal siding and roofing and a five-panel wood door, in ruinous condition. No alterations are apparent, and the scale retains a moderate degree of integrity.

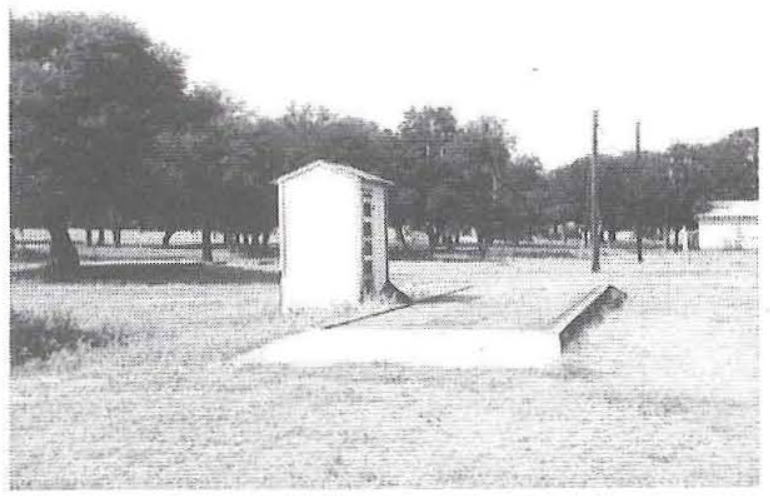

Figure 28. View to the southwest of Historic Resource No. 6 , truck scale. 
Historical Background: Located east of the entrance to the Dairy and Hog Farm in the dairy operations area of the facility, this structure assisted in the agricultural mission of the farm through its ability to weigh trucks entering and exiting the farm. Trucks arriving to remove livestock would drive onto the scale, and the truck's weight would be noted. After loading, the truck would be weighed again, and the difference would indicate the weight of the load. This structure is associated with the second phase of operations at the farm, after hog production became the sole focus of efforts.

Assessment: Because this scale is not yet 50 years of age, is not associated with the first phase of operations at the farm, and is not exceptional or rare, it is recommended that it be considered not eligible for listing in the National Register of Historic Places or for designation as a State Archeological Landmark.

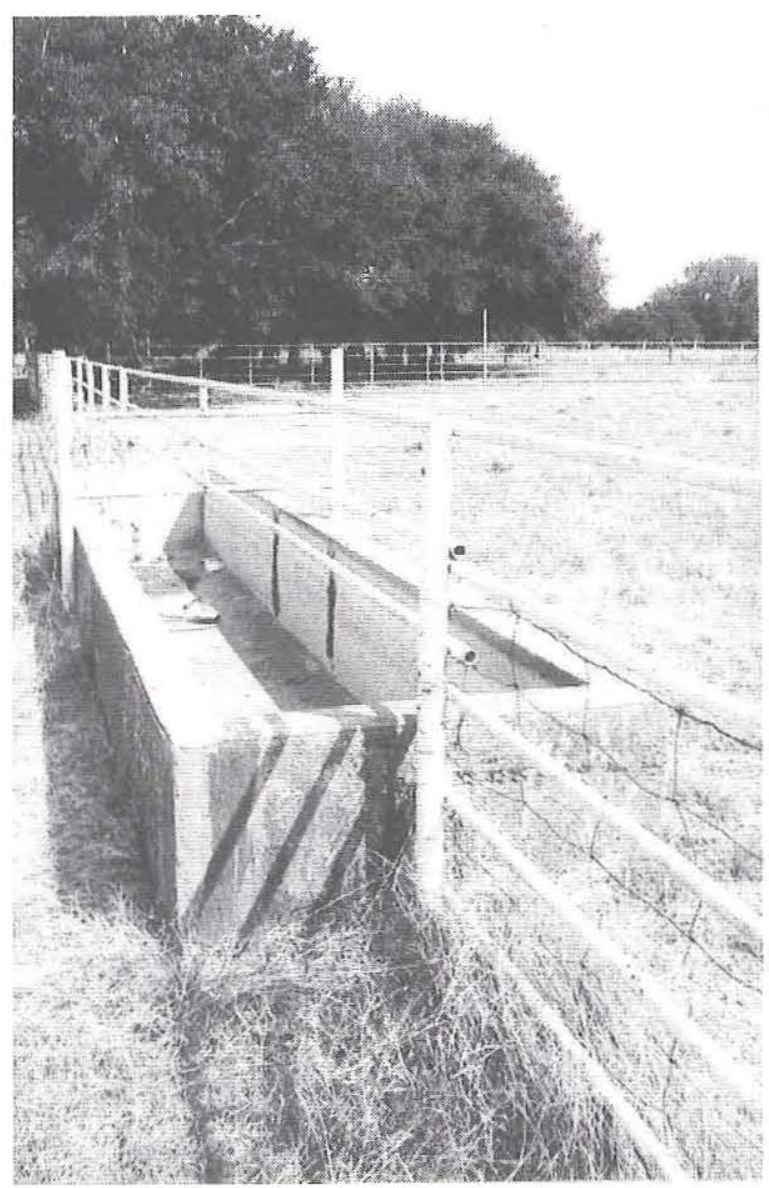

Historic Resources Nos. 7, 9, and 16, Water Troughs

Building No.: ?

Function: Water troughs

Construction Date: ca. 1943

Description: These three water troughs are constructed of poured concrete (Figure 29). Each has a metal pipe for delivering water to the trough as a primary distinguishing feature. Historic Resources Nos. 9 and 16 also have a metal grate at one end, while Historic Resource No. 7 lacks a grate. The troughs retain a moderate degree of integrity.

Historical Background: Located east of the entrance to the Dairy and Hog Farm in the dairy operations area of the facility, these structures assisted in the agricultural mission of the farm by providing water to livestock. Built as part of the

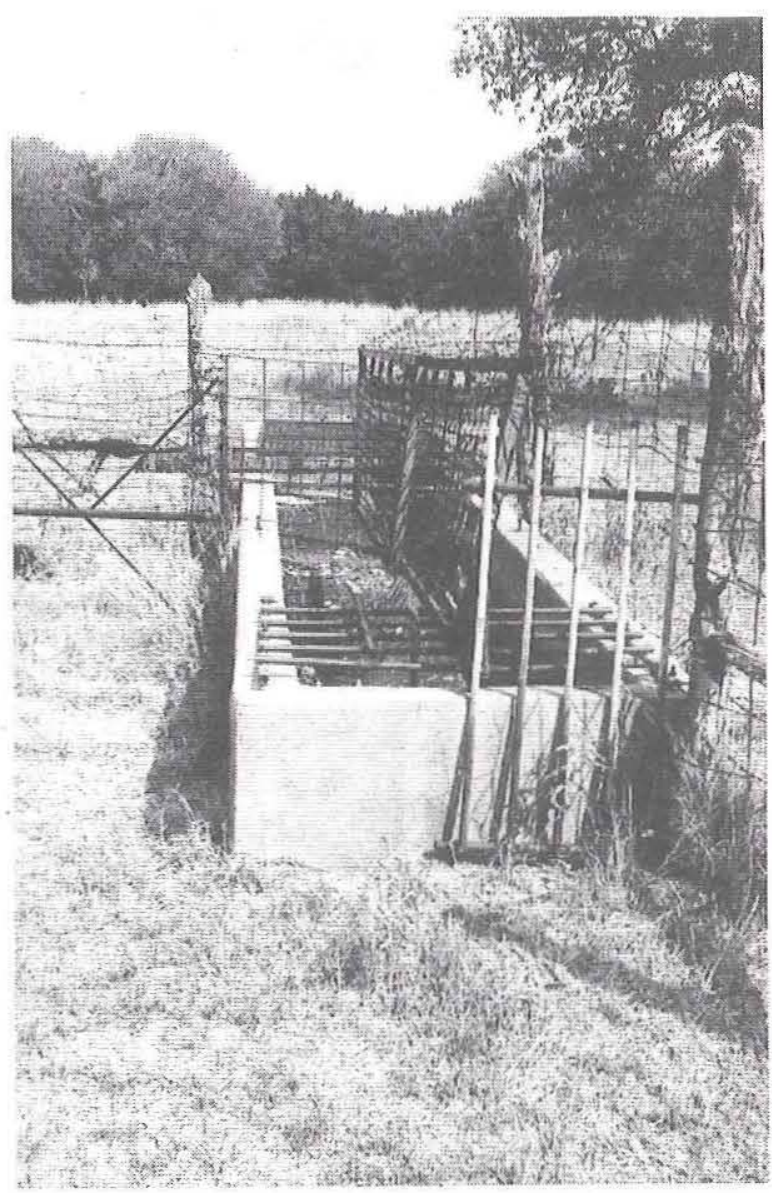

Figure 29. Views to the northeast of Historic Resources Nos. 7 (left) and 9 (right), water troughs. 
original dairy operations, they are associated with the initial development of the facility.

Assessment: These water troughs are associated with the mission of the farm between 1942 and 1951 and contribute to an understanding of the uses and development of the State Dairy and Hog Farm in that period. Three of 21 buildings and structures associated with the initial use of the facility, they are significant for the secondary role they played in the operations of the farm. The troughs retain a moderate degree of integrity and are recognizable to their date of construction. For these reasons, it is recommended that they be considered eligible for listing in the National Register of Historic Places under Criterion $\mathrm{A}$ as Contributing properties within the State Dairy and Hog Farm Administrative, Residential, and Dairy Operations Historic District and for designation as State Archeological Landmarks.

\section{Historic Resource No. 8, Water Fountain}

Building No.: ?

Function: Water fountain

Construction Date: ca. 1970

Description: This drinking fountain is constructed of a metal pipe to serve as a stand and a metal bowl (Figure 30). Adjacent to the fountain is a water valve sheathed in a section of PVC pipe. The valve delivers water to the fountain. The fountain has a moderate degree of integrity.

Historical Background: Located east of the entrance to the Dairy and Hog Farm in the dairy operations area of the facility, this structure apparently was erected of older recycled parts. It is associated with the Leander Rehabilitation Center's use of the facility, and not with the agricultural programs of the farm.

Assessment: Because this water fountain is not yet 50 years of age, is not associated with the historic farming context of the property, and is not exceptional or rare, it is recommended that it be considered not eligible for listing in the National Register of Historic Places or for designation as a State Archeological Landmark.

\section{Historic Resource No. 10, Bull Barn}

Building No.: ?/8123

Function: Bull barn

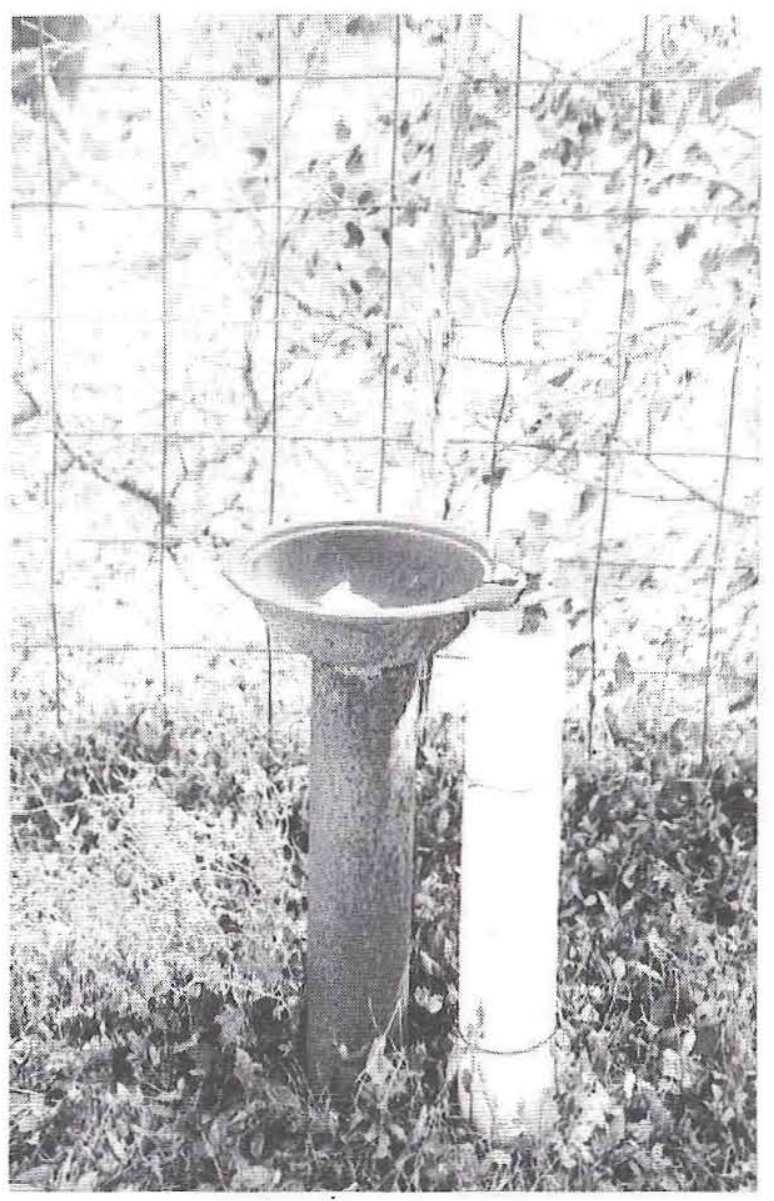

Figure 30. View to the northeast of Historic Resource No. 8, water fountain.

Construction Date: ca. 1943

Description: This one-story, wood-frame, rectangular-plan pole barn faces west and is covered by a corrugated metal shed roof and siding (Figure 31). The west wall is partially enclosed with horizontal shiplap siding, with an opening for ventilation and light at the southwest corner of the facade and a door at the northwest corner. No alterations are apparent. In fair condition, it retains a moderate amount of architectural integrity.

Historical Background: Located east of the entrance to the Dairy and Hog Farm in the dairy operations area of the facility, this barn was used as a shelter for the farm's bulls. The barn was erected during the initial phase of farm operations when it supplied both dairy and pork products to Austin's eleemosynary institutions.

Assessment: The barn is associated with the mission of the farm between 1942 and 1951 and 


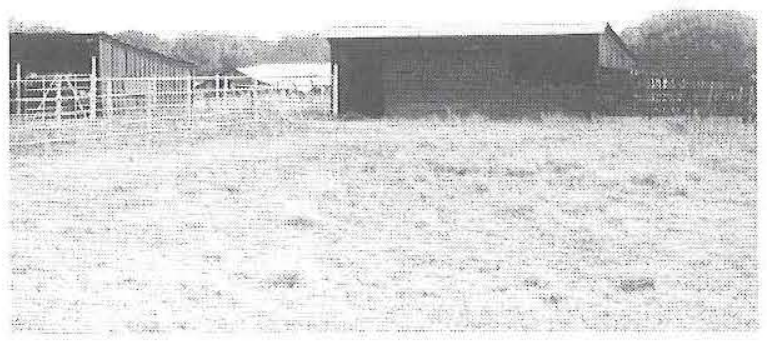

Figure 31. View to the northeast of Historic Resource No. 10, bull barn.

contributes to an understanding of the uses and development of the State Dairy and Hog Farm in that period. One of 21 buildings and structures associated with the early phases of use of the facility, it is significant for the secondary role it played in the operations of the farm. The barn retains a moderate degree of integrity and is recognizable to its date of construction. For these reasons, it is recommended that this barn be considered eligible for listing in the National Register of Historic Places under Criterion A as a Contributing property within the State Dairy and Hog Farm Administrative, Residential, and Dairy Operations Historic District and for designation as a State Archeological Landmark.

\section{Historic Resource No. $\mathbb{1 1}$, Mule Barn}

Building No.: ?/8124

Function: Mule barn

Construction Date: ca. 1943

Description: This one-story, wood-frame, rectangular-plan pole barn faces west and is covered by a corrugated metal shed roof and vertically laid flush siding (Figure 32). The west wall is partially enclosed with metal mesh screening at the north end, an alteration that only slightly detracts from the barn's integrity. In fair condition, it retains a moderate degree of architectural integrity.

Historical Background: Located east of the entrance to the Dairy and Hog Farm in the dairy operations area of the facility, this barn was used as a shelter for the farm's mules. The barn was erected during the initial phase of farm operations

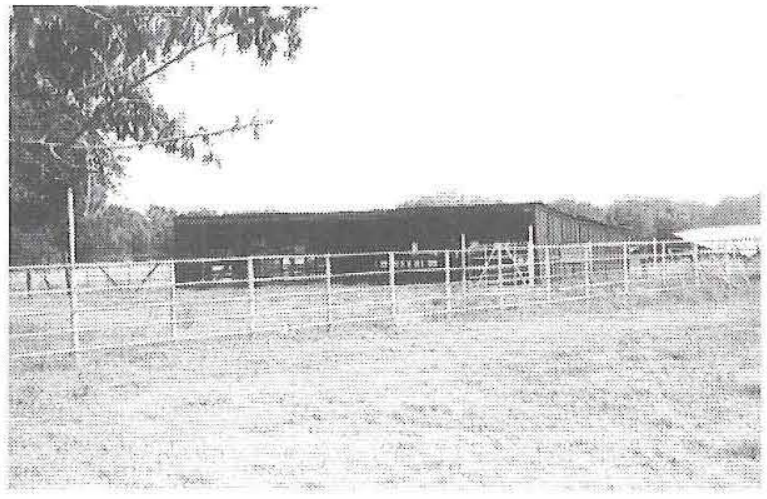

Figure 32. View to the northeast of Historic Resource No. 11, mule barn.

when it supplied both dairy and pork products to Austin's eleemosynary institutions.

Assessment: The barn is associated with the mission of the farm between 1942 and 1951 and contributes to an understanding of the uses and development of the State Dairy and Hog Farm in that period. One of 21 buildings and structures associated with the initial use of the facility, it is significant for the secondary role it played in the operations of the farm. The barn retains a moderate degree of integrity and is recognizable to its date of construction. For these reasons, it is recommended that this barn be considered eligible for listing in the National Register of Historic Places under Criterion A as a Contributing property within the State Dairy and Hog Farm 'Administrative, Residential, and Dairy Operations Historic District and for designation as a State Archeological Landmark.

\section{Historic Resources Nos. 12, 13, and 14, Calf Feeder Sheds}

Building No.: ?

Function: Calf feeder sheds

Construction Date: ca. 1950

Description: These three front-gabled sheds are less than one story in height and are constructed of wood frame with wood siding (Figure 33). Placed directly on the ground facing south, they have a single entry in the gable end to permit calves to access special feed. No alterations are apparent. In fair condition, these sheds retain a moderate amount of architectural integrity.

Historical Background: Located east of the entrance to the Dairy and Hog Farm in the dairy 


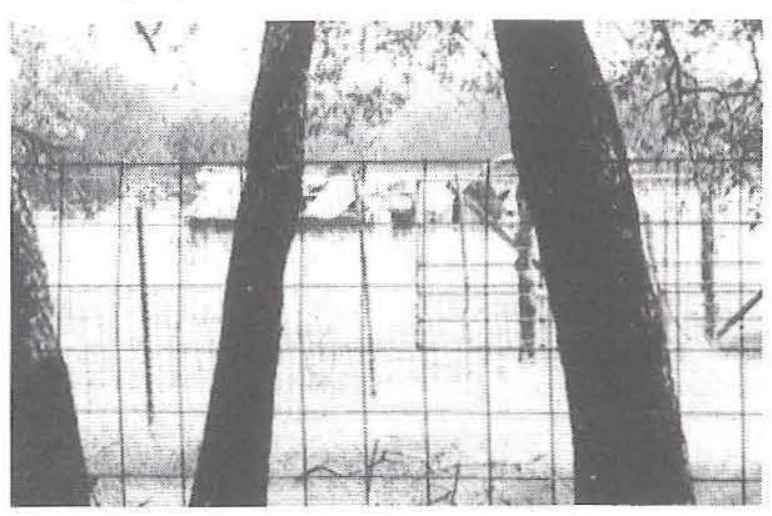

Figure 33. View to the northeast of Historic Resources Nos. 12, 13, and 14, calf feeder sheds.

operations area of the facility, these sheds were used as feeders for calves. They were erected during the period when the farm supplied both dairy and pork products to Austin's eleemosynary institutions.

Assessment: The sheds are associated with the mission of the farm between 1942 and 1951 and contribute to an understanding of the uses and development of the State Dairy and Hog Farm in that period. Three of 21 buildings and structures associated with the early use of the facility, they are significant for the secondary role they played in the operations of the farm. The sheds retain a moderate degree of integrity and are recognizable to their date of construction. For these reasons, it is recommended that they be considered eligible for listing in the National Register of Historic Places under Criterion $\mathrm{A}$ as Contributing properties within the State Dairy and Hog Farm Administrative, Residential, and Dairy Operations Historic District and for designation as State Archeological Landmarks.

\section{Historic Resource No. 15, Feed Trough}

Building No.: ?

Function: Feed trough

Construction Date: ca. 1950

Description: This cattle feed trough is constructed of poured concrete that bears the pattern of its wood form and is sheltered by a side-gabled corrugated metal roof supported on metal poles (Figure 34). A horizontal pole attached to vertical members runs the length of the concrete trough. In fair condition, it appears unaltered and retains a moderate degree of integrity.

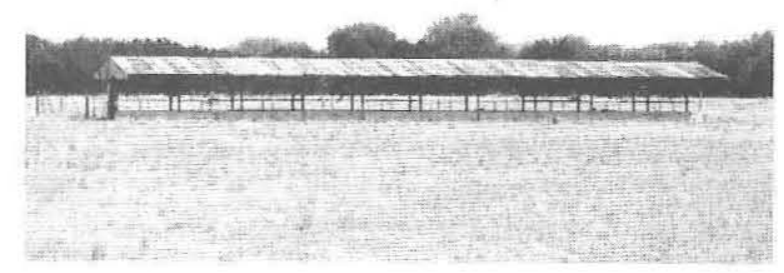

Figure 34. View to the northeast of Historic Resource No. 15, feed trough.

Historical Background: Located east of the entrance to the Dairy and Hog Farm in the dairy operations area of the facility, this structure assisted in the agricultural mission of the farm by providing feed for livestock. Built as part of the original dairy operations, this structure is associated with the early phases of development of the facility. Identical in form to, but somewhat larger than, the feed trough at Historic Resource No. 32d at the old Rhodes farm, this trough is one of two that survive on the property. Its design is attributed to programs at Texas A\&M University. According to informant testimony, similar feed troughs were in use prior to 1950. However, they lacked the horizontal bar that stretches end to end in this structure. Cows tend to feed by reaching forward, taking a large mouthful of hay, raising their heads and stepping back to chew. In the process, they drop excess hay on the ground, which then has to be raked up and returned to the trough or discarded. The design of this structure is a marked improvement in that a horizontal bar is placed across the vertical "stall" dividers that prevents the cows from raising their heads and stepping back. They quickly learn to feed with their heads down and over the trough so that excess hay falls back into the trough and is not wasted.

Assessment: This feed trough is associated with the mission of the farm between 1942 and 1951 and contributes to an understanding of the uses and development of the State Dairy and Hog Farm in that period. One of 21 buildings and structures associated with the early phases of use of the facility, it is significant for the secondary role it played in the operations of the farm. It also may be significant for its design. The trough retains a 
moderate degree of integrity and is recognizable to its date of construction. For these reasons, it is recommended that this trough be considered eligible for listing in the National Register of Historic Places under Criteria $\mathrm{A}$ and $\mathrm{C}$ as a Contributing property within the State Dairy and Hog Farm Administrative, Residential, and Dairy Operations Historic District and for designation as a State Archeological Landmark.

\section{Historic Resource No. 17, Fence}

Building No.: ?

Function: Fence

Construction Date: ca. 1943

Description: Constructed from rectangular mesh wire strung on wood and metal poles (Figure 35), this fence is a remnant of similar original fencing scattered throughout the project area. The introduction of metal poles as replacements for original wood posts has diminished the fence's integrity somewhat. However, the fencing is recognizable to its date of construction and retains a moderate degree of integrity.

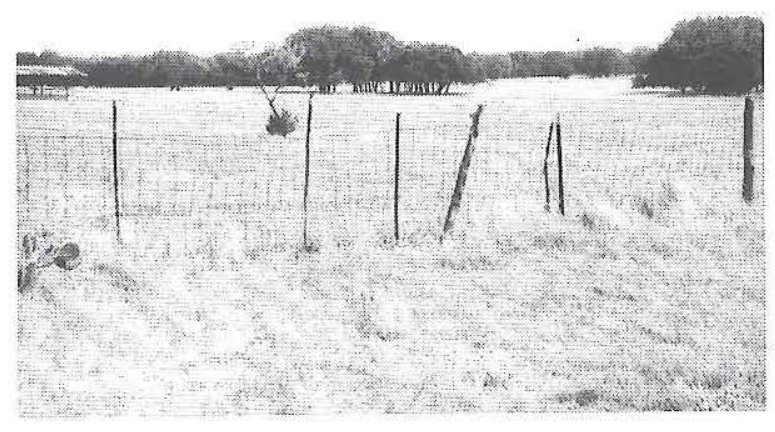

Figure 35. View to the northeast of Historic Resource No. 17 , fence.

Historical Background: Located east of the entrance to the Dairy and Hog Farm in the dairy operations area of the facility, this structure assisted in the agricultural mission of the farm by separating livestock areas from vehicular and pedestrian areas. Built as part of the original dairy operations, the fencing is associated with the initial development of the facility.

Assessment: The fencing is associated with the mission of the farm between 1942 and 1951 and contributes to an understanding of the uses and development of the State Dairy and Hog Farm in that period. One of 21 buildings and structures associated with the initial use of the facility, it is significant for the secondary role it played in the operations of the farm. The fencing retains a moderate degree of integrity and is recognizable to its date of construction. For these reasons, it is recommended that it be considered eligible for listing in the National Register of Historic Places under Criterion $\mathrm{A}$ as a Contributing property within the State Dairy and Hog Farm Administrative, Residential, and Dairy Operations Historic District and for designation as a State Archeological Landmark.

Historic Resources Nos. 18-20 and 22-24, Group Sheds/Dormitories

Building Nos.: 669/8144, 670/8145, 671/8146, $672 / 8147,674 / 8149$, and $675 / 8150$

Function: Group sheds/dormitories

Construction Date: ca. 1955

Description: These six buildings are one-story, wood-frame, rectangular-plan pole barns that have been converted into dormitories (Figure 36). They rest on concrete slab foundations and have sidegabled corrugated metal roofs. The buildings face south and have full-width attached porches with flat roofs supported on square wood posts. The porch floors are at-grade concrete slabs. The front and rear walls of the buildings are plywood; the end walls are corrugated metal. Three of the buildings have corrugated metal- sided water heater sheds attached to their east end walls. Fenestration is comprised of aluminum-frame double-hung sash windows arranged roughly equidistant in the front and rear walls. Entry is through plywood doors in the front and rear walls. Originally six of seven pole barns designed to serve as group sheds for hogs, these buildings were modified about 1975 into "rough-out," or camping, dormitories for Department of Mental Health and Mental Retardation clients. The alterations have significantly modified the buildings' original appearance by enclosing the formerly open fronts and installing windows and doors and changing the use from agricultural to domestic. Because of the changes, the buildings no longer retain sufficient integrity to be recognizable to their date of construction. They have a low 

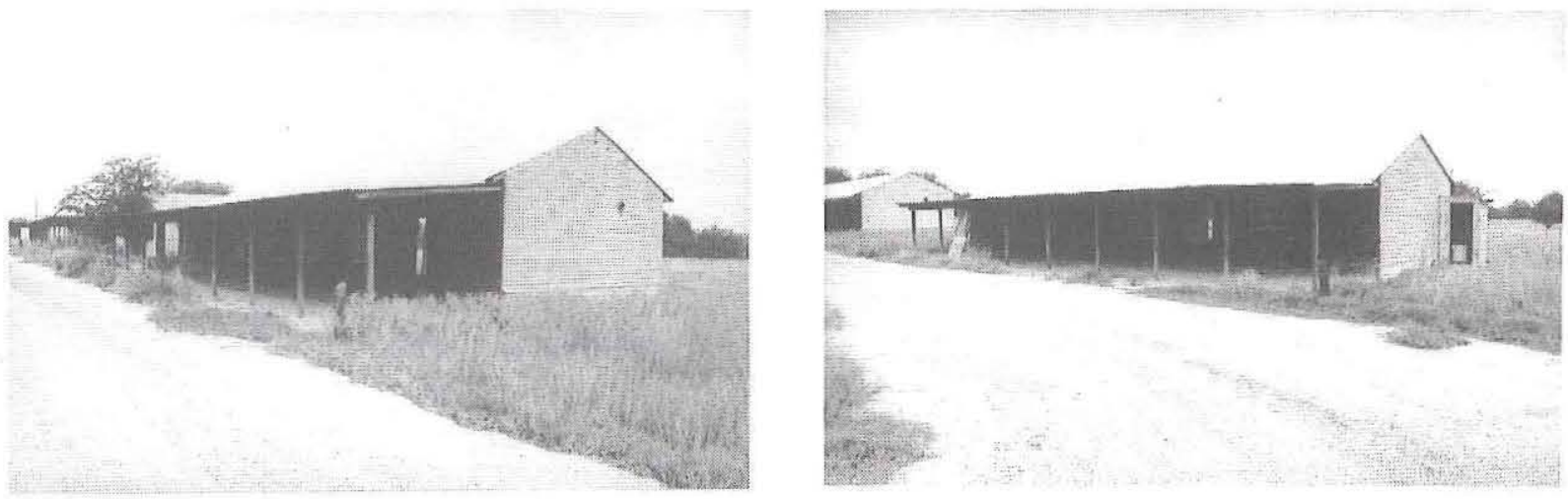

Figure 36. View to the northwest of Historic Resources Nos. 22 (left) and 23 (right), group sheds/dormitories.

degree of architectural integrity.

Historical Background: Located on the former Rhodes farmstead, these identical barns were built along an unpaved road during the second phase of the farm's operations when hog raising was the sole agricultural activity. These barns served as group sheds for hogs during their maturation period. This area also had 52 farrowing sheds for sows and piglets. Nearby, to the east, was another complex of 52 farrowing sheds and 7 group sheds built between 1948 and 1951. About 1975, after the agricultural operations had ceased, these barns were converted to dormitories for use by visiting clients participating in camping experiences. Associated with the converted use of these buildings is a kitchen-laundrybathroom facility, constructed about 1975 (Historic Resource No. 21). It is located between the first three and the last three barn/dorms in this area of the facility.

Assessment: Because these barns are not yet 50 years of age and no longer retain their architectural integrity, it is recommended that they be considered not eligible for listing in the National Register of Historic Places or for designation as State Archeological Landmarks.

\section{Historic Resource No. 21, Kitchen, Laundry, and Restroom}

Building No.: ?/8148

Function: Kitchen, laundry, and restroom

Construction Date: ca. 1955

Description: This one-story, wood-frame, front-gabled kitchen-laundry-restroom (Figure 37) has a corrugated metal roof and walls and rests on a concrete slab foundation. Wood posts and a wood "porch" railing at the front impart a residential look to the building. Behind the railing is an open area divided by a double sink. At the rear of the building are the remains of laundry and what appear to be toilet facilities. Appliances and most plumbing have been removed from the building, which is in poor condition. It has a low degree of architectural integrity.

Historical Background: Constructed between the first three and the last three barn/dormitory buildings in the 1955 hog raising area (Historic Resources Nos. 18-20 and 22-24), this building apparently was erected to provide operational support as a housekeeping facility for the campers using the adjacent converted barns. It appears to have replaced the seventh group shed. A concrete block restroom building, constructed about 1975 , is directly across the road from the kitchen.

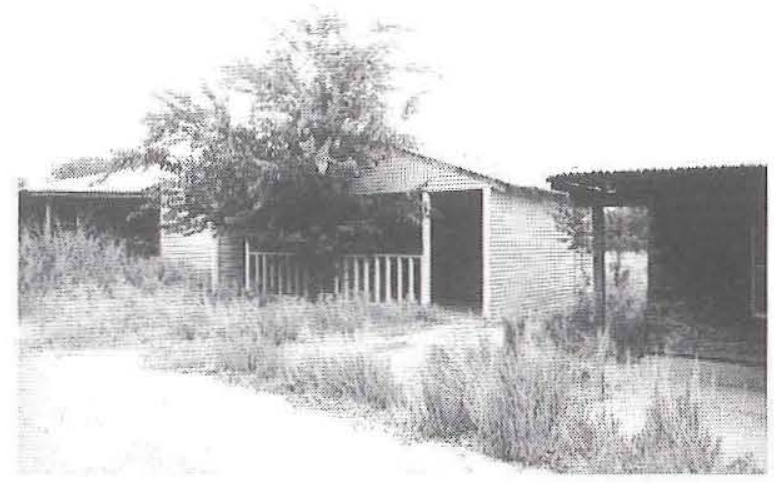

Figure 37. View to the northwest of Historic Resource No. 21, kitchen-laundry-restroom. 
Assessment: This building was constructed after the historic period and is unrelated to the historic context of the State Dairy and Hog farm's agricultural operations. It is not rare or exceptional in design or use and has no known significant historical associations. It is recommended that it be considered not eligible for listing in the National Register of Historic Places or for designation as a State Archeological Landmark.

\section{Historic Resource No. 25a, Culvert}

Building No.: ?

Function: Culvert

Construction Date: ca. 1955

Description: This culvert (Figure 38) was designed to channel wastewater from the adjacent hog sheds under the road to the spreading grounds on the opposite side. The culvert consists of a metal drain pipe connected to a poured-in-place concrete head wall at each end of the pipe. Associated with the culvert is a concrete drain pipe that extends from the barn/dormitory buildings to the north. The culvert appears unaltered and retains a high degree of integrity.

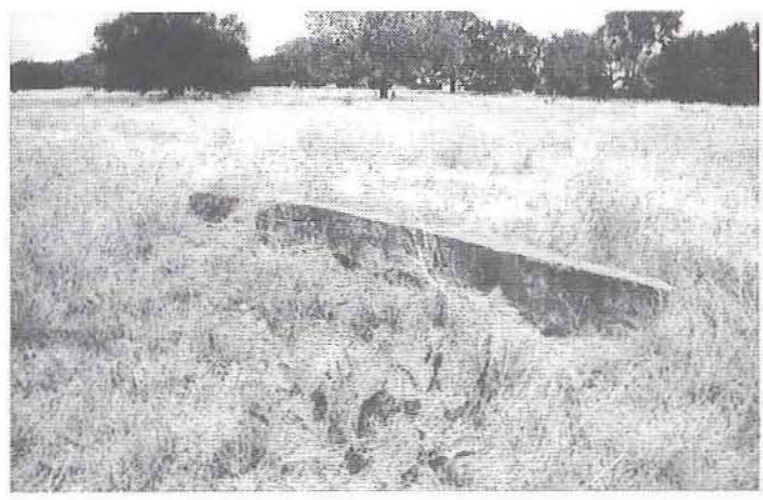

Figure 38. View to the northwest of Historic Resource No. 25a, culvert.

Historic Background: This culvert is one of three similar infrastructural elements at the farm (Historic Resources Nos. 25a, 25b, and 25c). On the north side of the road, the culvert attaches to a concrete drain pipe that brought the feed and manure runoff from the ca. 1955 barn/dormitory buildings during the time they were used to shelter swine. It provides a record of the way agricultural waste was handled at the facility in the 1950s and 1960s.
Assessment: This resource is a fragmentary part of the larger 1955 hog facility. Because it is not yet 50 years old, is a fragmentary resource, and is not rare or exceptional, it is recommended that it be considered not eligible for listing in the National Register of Historic Places or for designation as a State Archeological Landmark.

Historic Resources No. 25b and 25c, Culverts

Building No.: ?

Function: Culverts

Construction Date: ca. 1943

Description: These two culverts were designed to channel rain runoff under the main road into the dairy operations area of the farm. Both culverts contain a cattle guard attached to two poured-inplace concrete head walls. A metal drain pipe also is connected to the head walls. A third culvert, constructed about 1955, is located in the hog-raising area of the farm to the southeast (Historic Resource No. 25a). The culverts appear unaltered, and they retain a high degree of integrity.

Historic Background: These culverts are thought to be part of the original infrastructure system at the farm and are associated with the first phase of construction between 1942 and 1951. The presence of the cattle guards places them in this period and is a strong reminder of the original dual agricultural purpose of the facility. One culvert is located just east of the storekeeper/accountant's office and warehouse (Historic Resource No. 1). The other is found adjacent to the livestock chute (Historic Resource No. 36).

Assessment: These resources are significant for the minor role they played in the successful operations of the farm between 1943 and 1951. They are among the few extant resources directly associated with the dairy operations and retain a high degree of integrity. For these reasons, it is recommended that these culverts be considered eligible for listing in the National Register of Historic Places under Criterion A as Contributing properties within the State Dairy and Hog Farm Administrative, Residential, and Dairy Operations Historic District and for designation as State Archeological Landmarks.

Historic Resource No. 26, Water Trough

Building No.: ? 
Function: Water trough

Construction Date: ca. 1950

Description: This water trough is constructed of poured concrete (Figure 39). A metal pipe for delivering water to the trough and a metal grate at one end are the primary distinguishing features of this agricultural structure. Similar to water troughs in the dairy operations area of the facility (Historic Resources Nos. 7 and 9), this trough retains a moderate degree of integrity. Other features located in the vicinity are two pole barns, concrete foundations used for hog pens, and two feed troughs (Historic Resources Nos. 27-31). Nearby are a culvert and concrete drainpipe (Historic Resources Nos. 25a and 35).

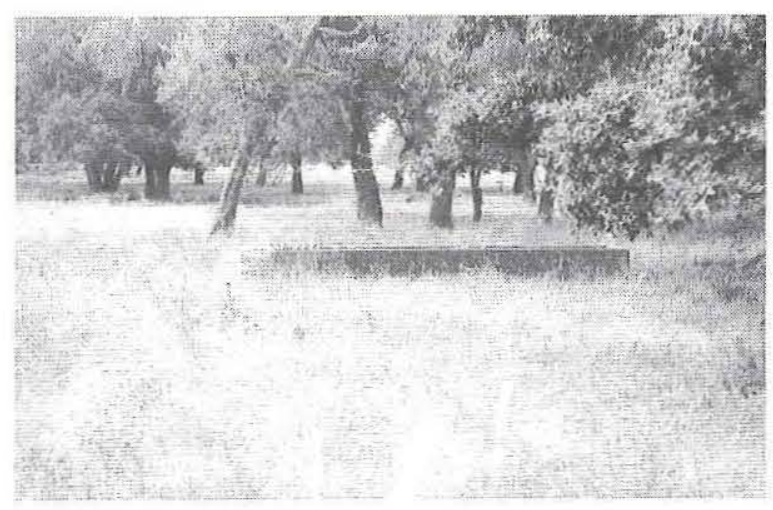

Figure 39. View to the south of Historic Resource No. 26 , water trough.

Historical Background: Located on the former Rhodes farmstead, this trough was part of the hog operations. Across the road are 2 pole barns (Historic Resources Nos. 27 and 30), which are the primary remnants of a complex that included 7 group sheds and 52 farrowing sheds built about 1950. This resource is part of the expansion of the hog operations begun in 1946 that culminated with the 1951 change in agricultural missions from combined dairy and hog programs to a solely swine operation.

Assessment: This resource is a fragmentary part of the larger hog facility. Because it is not yet 50 years old, is a fragmentary resource, and is not rare or exceptional, it is recommended that it be considered not eligible for listing in the National Register of Historic Places or for designation as a State Archeological Landmark.
Historic Resources Nos. 27 and 30, Pole Barns/Group Sheds

Building No.: $620 / 8126$ and $690 / 8162$

Function: Pole barns/group sheds

Construction Date: ca. 1950

Description: These are two one-story woodframe pole barns with side-gabled roofs and corrugated metal walls (Figure 40). The fronts of both barns, which face south, are open. Support for the roofs along the open fronts is provided by wood posts (Historic Resource No. 27) or metal Lally columns (Historic Resource No. 30). Historic Resource No. 27 is in poor condition, with part of the rear wall missing; no alterations are apparent. Historic Resource No. 30 is in fair condition; it has been altered with the installation of a metal water tank at its east end, and a metal bed frame with integral springs is attached to the wall as a kind of trellis. In front of the barns are two narrow, belowgrade concrete and pebble feed troughs (Historic Resources Nos. 29 and 31).

Historical Background: Located on the former Rhodes farmstead, these barns were part of the hog operations that began to expand in the late 1940s. Across the road is a concrete water trough (Historic Resource No. 26). Nearby are fencing remnants and a culvert and concrete sewer pipe (Historic Resources Nos. 25a, 28, and 35). These barns are the surviving primary remnants of a complex that included 7 group sheds and 52 farrowing sheds built about 1950. According to informant testimony, the 7 group sheds, of which these are 2, were designed by Jack Goodman of Barnes, Landis and Goodman, an Austin architectural firm, to specifications prepared by facility personnel. The barns are similar to standard pole barns used widely in Texas. These resources are part of the expansion of the hog operations that culminated with the 1951 change in agricultural missions from combined dairy and hog programs to a solely swine operation.

Assessment: These resources are fragmentary parts of the larger hog facility. Because they are not yet 50 years old, are fragmentary, and are not rare or exceptional, it is recommended that they be considered not eligible for listing in the National Register of Historic Places or for designation as State Archeological Landmarks. 

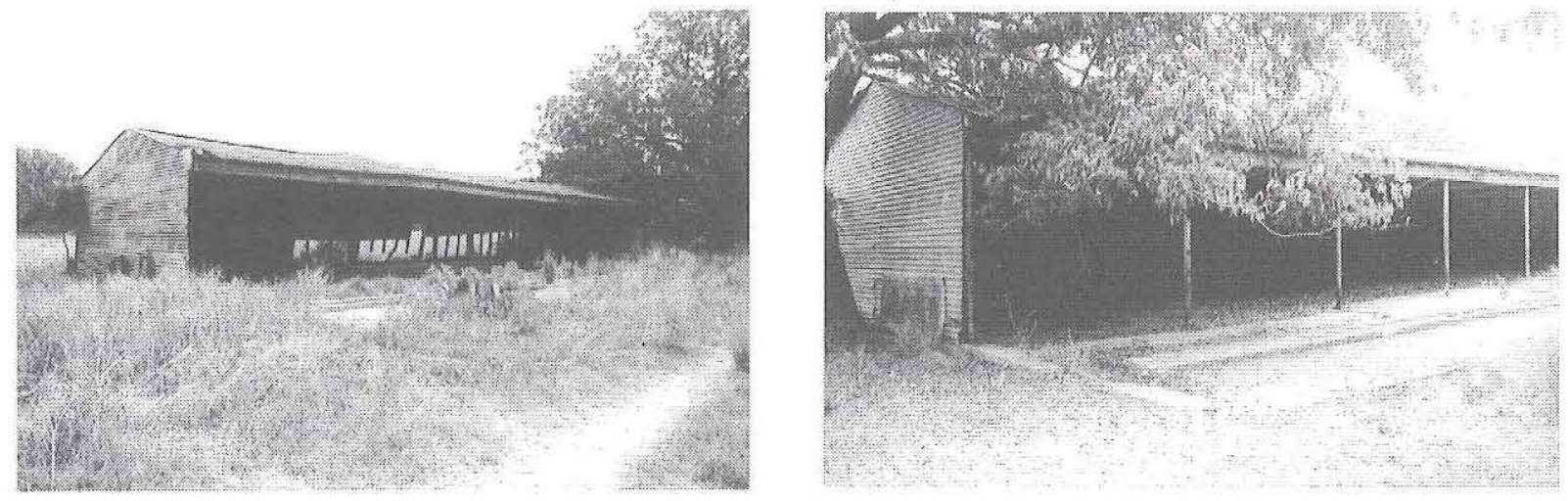

Figure 40. Historic Resources Nos. 27 (left; view to the northeast) and 30 (right; view to the southeast), pole barns/group sheds.

\section{Historic Resource No. 28, Fencing Foundation}

Building No.: ?

Function: Fencing foundation

Construction Date: ca. 1950

Description: This poured-in-place concrete foundation resembles a culvert head wall but contains holes on the top edge to accommodate fencing supports (Figure 41). Southeast of the administration-residential-dairying area, these foundations are scattered throughout the hog-raising portion of the farm that was developed between 1948 and 1955. These foundations held fencing made of World War II surplus bed frames and metal poles that created hog pens. Only the concrete foundations remain, compromising the integrity of the fencing.

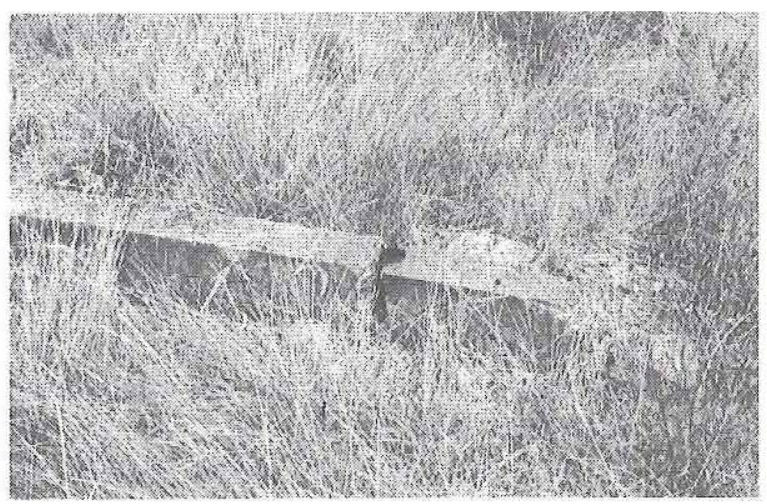

Figure 41. View to the northwest of Historic Resource No. 28, fencing foundation.

Historical Background: Located on the former
Rhodes farmstead, these foundations are scattered in the areas that contained the group sheds. Since hogs root, sturdy excavation-proof fencing is required to contain them within outdoor pens. These foundations are associated with the hog operations that began to expand in 1946 and are part of the second phase of agricultural operations at the farm that enlarged the hog operations and eventually terminated the dairy program.

Assessment: This resource is a fragmentary part of the larger hog facility. Because it is not yet 50 years old, is a fragmentary resource that has lost its integrity, and is not rare or exceptional, it is recommended that it be considered not eligible for listing in the National Register of Historic Places or for designation as a State Archeological Landmark.

\section{Historic Resources Nos. 29 and 31, Feed Troughs}

Building No.: ?

Function: Feed troughs

Construction Date: ca. 1950

Description: These hog feed troughs are constructed of poured concrete mixed with pebble aggregate (Figure 42). Divided into three compartments by sloping ramplike dividers, the troughs are placed in the ground in front of the pole barns recorded as Historic Resources Nos. 27 and 30. The slabs associated with the pole barns have a smooth finish, suggesting that they may have been poured at a different time. The troughs appear unaltered.

Historical Background: Located on the former Rhodes farmstead, these troughs are associated with the hog operations that began to expand in 1946. 


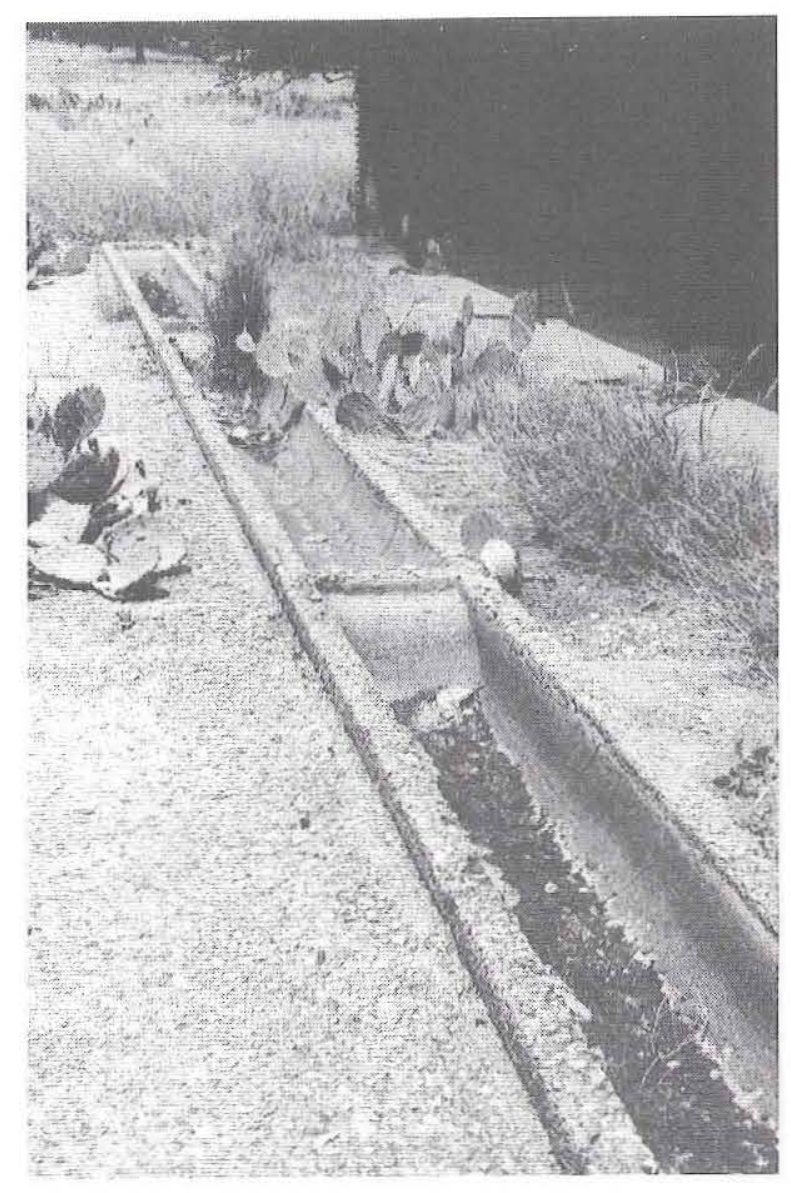

Figure 42. View to the northwest of Historic Resource No. 29, feed trough.

Behind the troughs are pole barns (Historic Resources Nos. 27 and 30). Across the road is a concrete water trough (Historic Resource No. 26). Nearby are fencing remnants and a culvert and concrete sewer pipe (Historic Resources Nos. 25a, 28 , and 35). These troughs are associated with the surviving primary remnants of a complex that included 7 group sheds and 52 farrowing sheds built between 1948 and 1951. They are associated with the hog operations that began to expand in 1946 and were part of the second phase of agricultural operations at the farm that enlarged the hog operations and eventually terminated the dairy program.

Assessment: These resources are fragmentary parts of the larger hog facility. Because they are not yet 50 years old, are fragmentary, and are not rare or exceptional, it is recommended that they be considered not eligible for listing in the National Register of Historic Places or for designation as State Archeological Landmarks.

\section{Historic Resource No. 32a, Swineherd Residence}

Building No.: ?

Function: Swineherd residence

Construction Date: ca. 1951

Description: This one-story, wood-frame, rectangular-plan dwelling rests on a pier-and-beam foundation and is distinguished by a partial-width attached porch, wood shiplap siding, 6/6 wood-frame double-hung sash windows, and a side-gabled composition shingle roof (Figure 43). The shed porch roof is supported on square wood posts. The porch floor is a raised concrete slab. The front door is placed slightly off center in the main elevation and has a wood panel front door and a wood screen door. No alterations are apparent. Original interior finishes include wood flooring, original panel doors, wood door and window moldings, and a stove vent in the kitchen ceiling. The house is in fair condition and retains a high degree of integrity. Other features located in the vicinity of the house are three water troughs, a feed trough, and a sheep dip tank (Historic Resources Nos. 32b-32f).

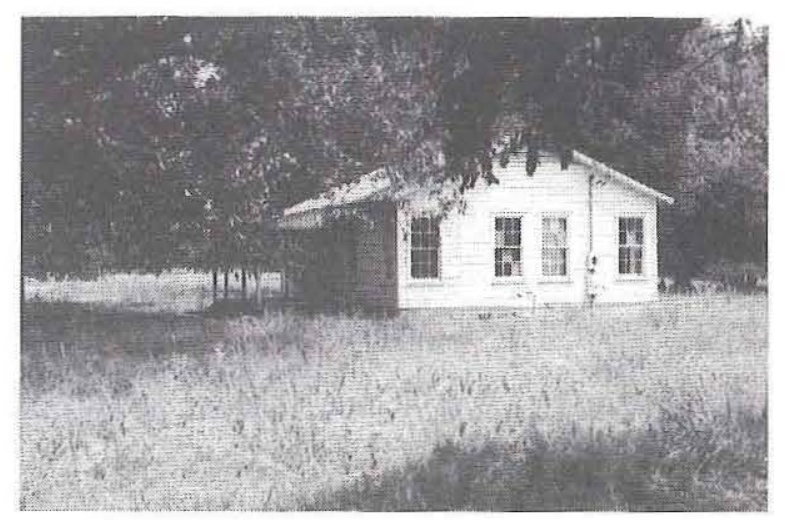

Figure 43. View to the northwest of Historic Resource No. 32a, swineherd residence.

Historical Background: Located on the former Rhodes farmstead adjacent to the site of the Rhodes farmhouse and barn, this dwelling was originally thought to have been built about 1948 and associated with the first phase of agricultural operations at the State Dairy and Hog Farm. However, informant data revealed that the house was constructed about 1951 in response to the increase in hog operations and was the swineherd's residence. It is associated with the third phase of operations at the facility that 
began in 1951 and focused solely on hog raising. The other resources recorded at this site are related geographically, but they are associated with three different periods of use at the property. Three were constructed during the operation of the Rhodes farm. The remaining resources were built after 1950 . Their fragmentary nature does not support strong associative connections, especially in view of surviving similar resources at the State Dairy and Hog Farm which do possess strong associations with the historic context as well as integrity of materials, setting, and feeling.

Assessment: Because the house is less than 50 years of age, is not exceptional in its design, construction, or use, and is a fragmentary resource associated exclusively with the hog operation, it is recommended that it be considered not eligible for listing in the National Register of Historic Places or for designation as a State Archeological Landmark.

\section{Historic Resource No. 32b, Sheep Dip Tank}

Building No.: ?

Function: Sheep dip tank

Construction Date: ca. 1937

Description: This below-grade sheep dip tank is constructed of concrete bearing the pattern of its corrugated metal form (Figure 44). In nearly ruinous condition, it retains a low degree of integrity. Other features located in the vicinity are the swineherd's house, three water troughs, and a feed trough (Historic Resources Nos. 32a and 32c-32f).

Historical Background: Located on the former Rhodes farmstead adjacent to the site of the Rhodes

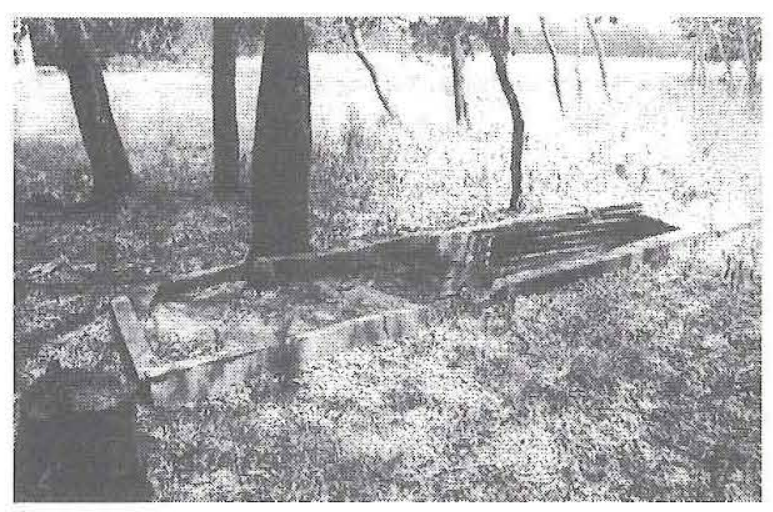

Figure 44. View to the northwest of Historic Resource No. 32b, sheep dip tank. farmhouse and barn and the swineherd's house, this agricultural feature was built about 1937 and was part of the operations of the Rhodes farm. Under legislation in effect in the $1930 \mathrm{~s}$, farmers and ranchers were required to treat their range and barnyard animals with tick-eradicating insecticides. Thus, dip tanks were erected widely. The size of this tank indicates it was used for sheep. According to informant data, it was present at the site in 1945 and was part of the Rhodes farm, all of which is now demolished except for this tank and two related water troughs.

Assessment: Because this structure is a fragmentary feature that has lost its associative nucleus, it is recommended that it be considered not eligible for listing in the National Register of Historic Places or for designation as a State Archeological Landmark.

\section{Historic Resource No. 32c, Water Trough}

Building No.: ?

Function: Water trough

Construction Date: ca. 1937

Description: This water trough is constructed of poured concrete bearing the pattern of its corrugated metal form (Figure 45). It appears unaltered and is in fair condition. It retains a moderate degree of integrity. Other features located in the vicinity are a dip tank, the swineherd's house, two water troughs, 'and a feed trough (Historic Resources Nos. 32a, 32b, and 32d-32f).

Historical Background: Located on the former Rhodes farmstead adjacent to the site of the Rhodes

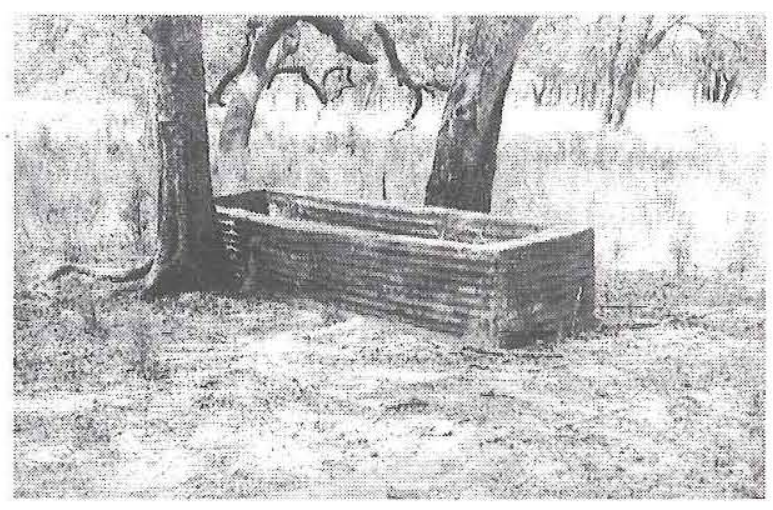

Figure 45. View to the southeast of Historic Resource No. 32c, water trough. 
farmhouse and barn and the swineherd's house, this agricultural feature was built about 1937 and was part of the operations of the Rhodes farm. According to informant data, it was present at the site in 1945 and was part of the Rhodes farm, all of which is now demolished except for this trough, a round concrete water trough, and a related sheep dip tank.

Assessment: Because this structure is a fragmentary feature that has lost its associative nucleus, it is recommended that it be considered not for eligible listing in the National Register of Historic Places or for designation as a State Archeological Landmark.

\section{Historic Resource No. 32d, Feed Trough}

Building No.: ?

Function: Feed trough

Construction Date: ca. 1950

Description: This cattle feed trough is constructed of poured concrete bearing the pattern of its wood form and sheltered by a side-gabled corrugated metal roof supported on metal poles (Figure 46). A horizontal pole attached to vertical members runs the length of the concrete trough. In fair condition, it appears unaltered and retains a moderate degree of integrity. Other features located in the vicinity are a dip tank, the swineherd's house, three water troughs, and a feed trough (Historic Resources Nos. $32 \mathrm{a}-32 \mathrm{c}, 32 \mathrm{e}$, and $32 \mathrm{f}$ ).

Historical Background: Located on the former Rhodes farmstead adjacent to the site of the Rhodes farmhouse and barn and the swineherd's house, this agricultural feature was built about 1950 and was part of the dairy operations at the State Dairy and

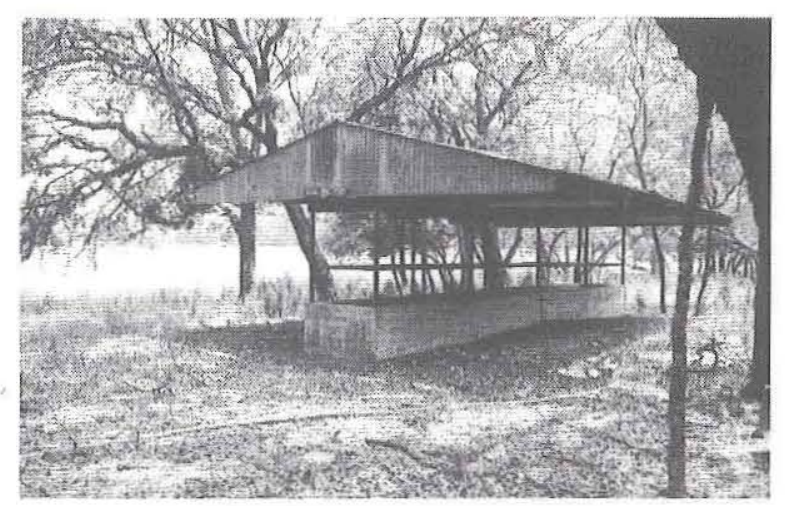

Figure 46. View to the northwest of Historic Resource No. $32 \mathrm{~d}$, feed trough.
Hog Farm. According to informant data, the gestating cows were segregated from the milk-producing cows in this area of the facility, and this trough was used as a hay feeder. Identical in form with, but somewhat smaller than the feed trough at Historic Resource No. 15 in the dairying area, this trough is one of two that survive on the property. Its design is attributed to programs at Texas A\&M University. Other agricultural features at the Rhodes farm that were likely used in the care of the gestating cows by the State include the log barn, now demolished, as well as the two water troughs at this location.

Assessment: Because this structure is a fragmentary feature that has lost its probable associative nucleus (the log barn), it is recommended that it be considered not eligible for listing in the National Register of Historic Places or for designation as a State Archeological Landmark.

\section{Historic Resource No. 32e, Water Trough}

Building No.: ?

Function: Water trough

Construction Date: ca. 1945

Description: This round water trough is constructed of smooth poured concrete (Figure 47). In fair condition, it appears unaltered and retains a moderate degree of integrity. Other features located in the vicinity are a dip tank, the swineherd's house, two water troughs, and a feed trough (Historic Resources Nos.' 32a-32d and 32f).

Historical Background: Located on the former Rhodes farmstead adjacent to the site of the Rhodes farmhouse and barn and the swineherd's house, this agricultural feature may have been part of the

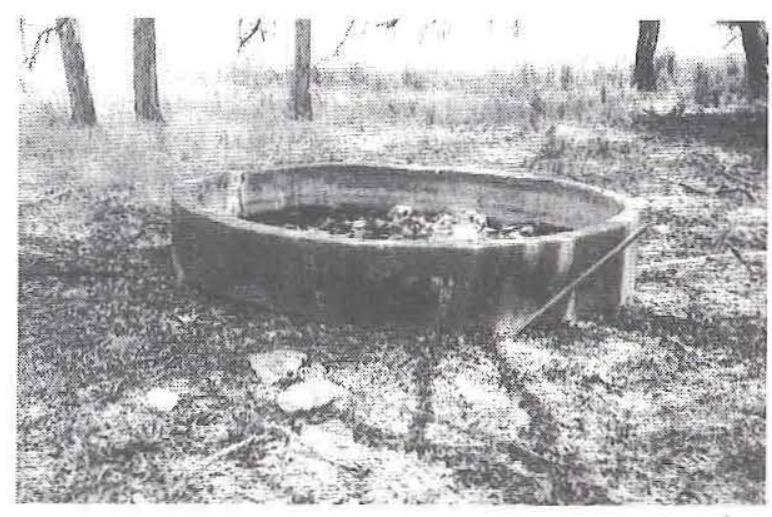

Figure 47. View to the northwest of Historic Resource No. $32 \mathrm{e}$, water trough. 
Rhodes farm operations and was used in the operations of the State Dairy and Hog Farm. According to informant data, this trough was moved to its present location in 1951 from where it was originally placed when the swineherd's house was built. It was originally located near the Rhodes farm house.

Assessment: Because this structure is a fragmentary feature that has been moved and is not yet 50 years of age, it is recommended that it be considered not eligible for listing in the National Register of Historic Places or for designation as a State Archeological Landmark.

\section{Historic Resource No. 32f, Water Trough}

Building No.: ?

Function: Water trough

Construction Date: ca. 1955

Description: This water trough is constructed of smooth poured concrete with pebble aggregate (Figure 48). In fair condition, it appears unaltered and retains a moderate degree of integrity. Other features located in the vicinity are a dip tank, the swineherd's house, two water troughs, and a feed trough (Historic Resources Nos. 32a-32e).

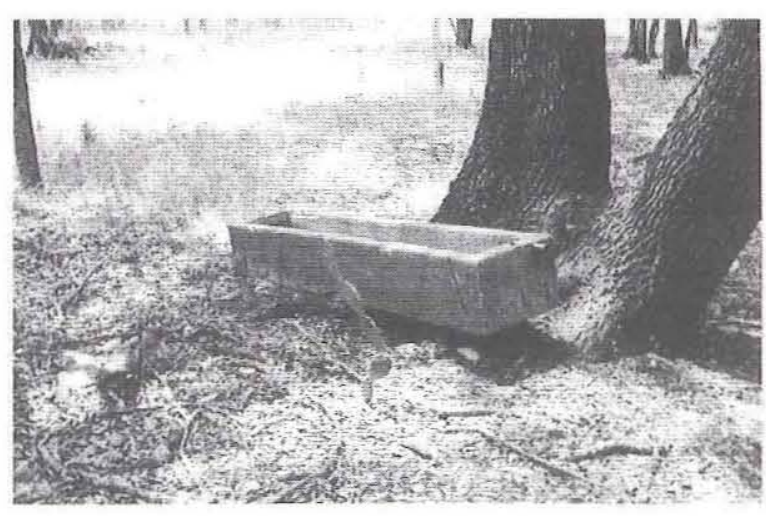

Figure 48. View to the southeast of Historic Resource No. $32 f$, water trough.

Historical Background: Located on the former Rhodes farmstead adjacent to the site of the Rhodes farmhouse and barn and the swineherd's house, this agricultural feature was used in the operations of the State Dairy and Hog Farm.

Assessment: Because this structure is less than 50 years of age, is not exceptional in its design, construction, or use, and is a fragmentary resource associated exclusively with the hog operation, it is recommended that it be considered not eligible for listing in the National Register of Historic Places or for designation as a State Archeological Landmark.

\section{Historic Resource No. 33, Kitchen, Dining Room, and Dormitory}

Building No.: 602/8121

Function: Kitchen, dining room, and dormitory Construction Dates: 1943, 1975

Description: This one-story, T-plan, yellow brick building (Figure 49) includes space for a kitchen, a dining room, and two dormitory rooms. The overall effect of the building is horizontal and somewhat sprawling. The kitchen area projects from the front of the dormitory, which faces west, forming the trunk of the $T$ plan. Immediately behind the kitchen is the dining room. Originally, it was divided into two small rectangular areas, one for African American patients and one for white patients. Behind the dining room is the dorm area, which is composed of two separate wings that flank the kitchen-dining area and form the arms of the $T$ plan. Resting on a concrete slab foundation, the dorm utilizes cavity-wall construction with the inner and outer brick walls separated by a narrow air space. The building has nonoriginal double-hung aluminum-sash windows in the dorm and kitchen areas installed inside the original window openings. The dining room and one window on the north end wall of the dorm retain their original steel-frame, fixed-pane, multilight windows. All interior walls, except those in the kitchen, are exposed brick, and the dorm and dining rooms have openings for wood stove pipes, the original heat source. Entry was originally through the kitchen at the front of the building or through the dormitory entrances that flanked the dining room and led to the segregated dorm areas. Original wood panel doors as well as replacement plywood hollow-core doors are found throughout the building. A cross-gable roof is covered with composition shingles. In addition to the window alterations, the entry into the north dorm wing, which housed African American patients, has been enclosed with plywood. The kitchen has been altered with the installation of plywood panels. In the dining room, the interior wall that originally divided the space into two segregated dining areas 


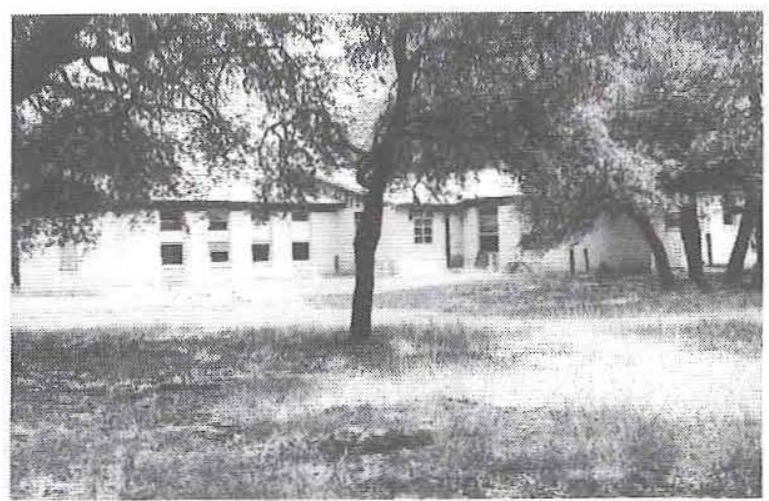

Figure 49. View to the southeast of Historic Resource No. 33, kitchen-dining room-dormitory.

has been removed. Decorative features include horizontal wood siding in the gable ends and wood knee braces. Because of the alterations to the windows and the modification on the north side of the building, it retains a moderate degree of architectural integrity.

Historical Background: Located near the site of the now-demolished dairy barn in the administrative-residential-dairy operations section of the farm, the dormitory is one of the six original permanent buildings and structures erected between 1943 and 1946 (Historic Resources Nos. 1, 2a, 3, 4, 33, and 34). The design of this building and the other five original resources is attributed to Walter C. Moore, Jr. Like the other four original brick buildings, it is of cavity-wall construction and is stylistically atypical in that it combines an early appearance of Ranch-style domestic design (i.e., the horizontal sprawling form of the building and the use of wood siding in the gable ends) with decorative features from the older Craftsman tradition (i.e., the wood knee braces located under the eaves).

Assessment: This is 1 of the 6 original permanent buildings and structures built at the farm and 1 of 21 buildings and structures associated with the initial use and development of the State Dairy and Hog Farm between 1942 and 1951. It contributes to an understanding of the mission of the facility during that period. It is significant for its role as living quarters for patients involved in the agricultural operations of the farm, for the ways in which it reflects the racial divisions of society as a whole, and for its association with the first phase of construction. The use of cavity-wall construction and the melding of Ranch-style and Craftsman-style design features suggest architectural significance as well. Although the alterations to the windows and the enclosure of the entry on the north side of the building have diminished its integrity, it retains sufficient original forms and materials to be recognizable to its date of construction. For these reasons, it is recommended that this building be considered eligible for listing in the National Register of Historic Places under Criteria $\mathrm{A}$ and $\mathrm{C}$ as a Contributing property within the State Dairy and Hog Farm Administrative, Residential, and Dairy Operations Historic District and for designation as a State Archeological Landmark.

\section{Historic Resource No. 34, Sewage Treatment Facility}

Building No.: ?

Function: Sewage treatment facility

Construction Date: 1943

Description: This rectangular-plan, poured-inplace concrete structure known as an Imhoff tank served as the sewage treatment facility for the State Dairy and Hog Farm (Figure 50). The tank is built into the slope of a hill exposing its west face, which reveals the impressions left by the wood plank form into which it was poured. The edges of the tank extend beyond the walls creating eavelike projections. Connected to the various residential buildings and the dairy barn by pipes, wastewater was channeled through the two-level chambered Imhoff tank, where anaerobic and aerobic digestion of wastes occurred, and then were distributed over designated spreading grounds northwest of the tank. Covering the tank is a heavy-gauge wire-mesh screen. This structure was part of the initial phase of construction at the farm and was one of six permanent buildings and structures erected there (Historic Resources Nos. $1,2 \mathrm{a}, 3,4,33$, and 34). No alterations are apparent, although the protective wire-mesh screen in damaged. The tank retains a high degree of architectural integrity.

Historical Background: Located north of the administrative, residential, and dairy operations area of the farm, this resource served an important role as the key element in the facility's infrastructure system. The design of this structure is based on similar wastewater treatment facilities originally designed by Dr. Karl Imhoff (1876-?), a German engineer. The Imhoff tank was developed prior to 1907 for the Enscher Sewage District in Germany. 


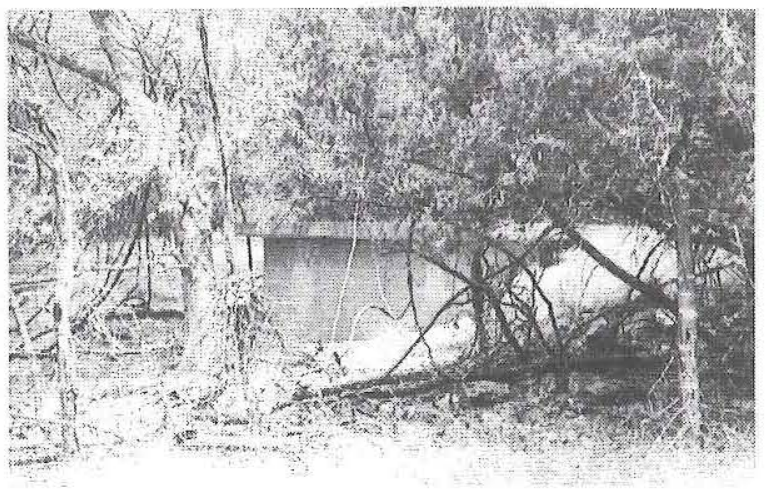

Figure 50. View to the northeast of Historic Resource No. 34 , sewage treatment facility.

It was introduced to the United States in 1907 as a patented device; it was widely used between that time and about 1960 for primary sewage treatment and in the associated preceding trickling filtration process. The Imhoff tank system was a significant advance over previously employed sewage treatment processes. It was in widespread use until the late 1930s for sewage treatment plants serving both large and small populations. Since the 1950s, installation of new Imhoff systems has decreased as technological advancements have increased efficiency and reduced costs.

A system similar to the Imhoff tank at the State Dairy and Hog Farm dating from 1917 was documented at Camp Bullis, Bexar County, Texas, in 1994 (Kibler and Gardner 1994). Another similar tank was documented in the City of Graham, Texas; it dates to about 1916 (Strong et al. 1996). Historic Resource No. 34 and the five brick buildings are attributed to Walter C. Moore, Jr.

Assessment: This is 1 of the 6 original permanent buildings and structures erected at the farm and 1 of 21 buildings and structures associated with the initial use and development of the State Dairy and Hog Farm between 1942 and 1951. It contributes to an understanding of the mission of the facility during that period. It is significant for its secondary role in the health and safety of the farm's personnel and patients as well as the agricultural operations, and as a representative example of a widely used sanitation system. It retains a high degree of integrity and is recognizable to its date of construction. For these reasons, it is recommended that this structure be considered eligible for listing in the National Register of Historic Places under Criteria A and $\mathrm{C}$ as a Contributing property within the State Dairy and Hog Farm Administrative, Residential, and Dairy Operations Historic District and for designation as a State Archeological Landmark.

\section{Historic Resource No. 35, Sewer Pipe}

Building No.: ?

Function: Sewer pipe

Construction Date: ca. 1955

Description: This concrete pipe (Figure 51) measures about 6 inches in diameter and connects square concrete clean-out traps evenly spaced about $6 \mathrm{ft}$ apart along the length of the pipe, which terminates at a culvert with a concrete head wall. A fragmentary part of a once-larger system, this portion of the pipe appears unaltered and retains a high degree of integrity.

Historical Background: Located on the former

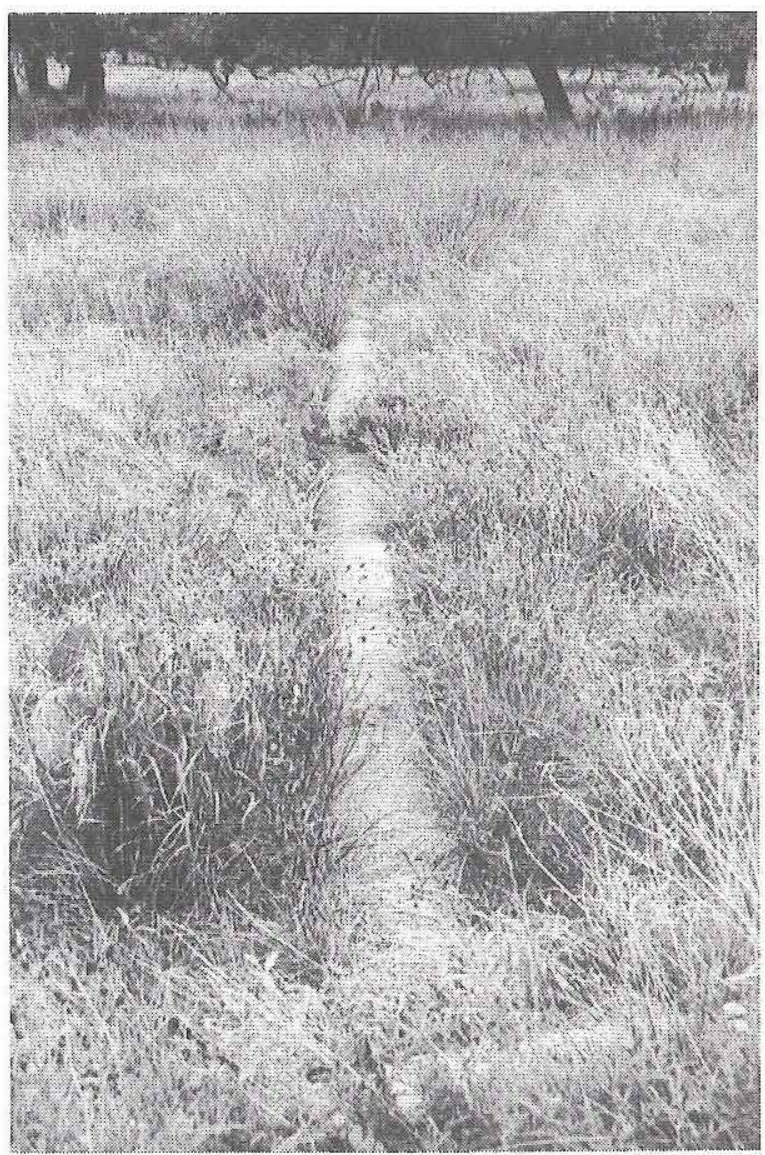

Figure 51. View to the southeast of Historic Resource No. 35, sewer pipe. 
Rhodes farmstead, this infrastructural resource was connected to the open feed troughs at the ca. 1955 group sheds. It is associated with the third phase of operations of the farm that focused solely on hog operations. The designer of the pipe is unknown.

Assessment: Because this structure is less than 50 years of age, is not exceptional in its design, construction, or use, and is a fragmentary resource associated exclusively with the post-1951 hog operation, it is recommended that it be considered not eligible for listing in the National Register of Historic Places or as a State Archeological Landmark.

\section{Historic Resource No. 36, Livestock Chute}

\section{Building No.: ?}

Function: Livestock chute

Construction Date: 1950

Description: This poured-in-place concrete livestock chute (Figure 52) was built about 1950 to replace the original chute, which was constructed of wood. The impressions left by the wood-plank form into which it was poured are still visible. The ramp of the chute is enclosed with chain-link fencing. No alterations are apparent, and the chute retains a high degree of integrity.

Historical Background: Located in the administrative, residential, and dairy operations area of the farm, the chute served an important secondary role in the management of livestock at the farm. This chute is a good representative example of livestock chutes built throughout Texas and the West.

Assessment: This livestock chute is 1 of 21 buildings and structures associated with the early use of the facility between 1942 and 1951. It contributes to an understanding of the mission of the facility during that period. It is significant for its secondary role in livestock management and the

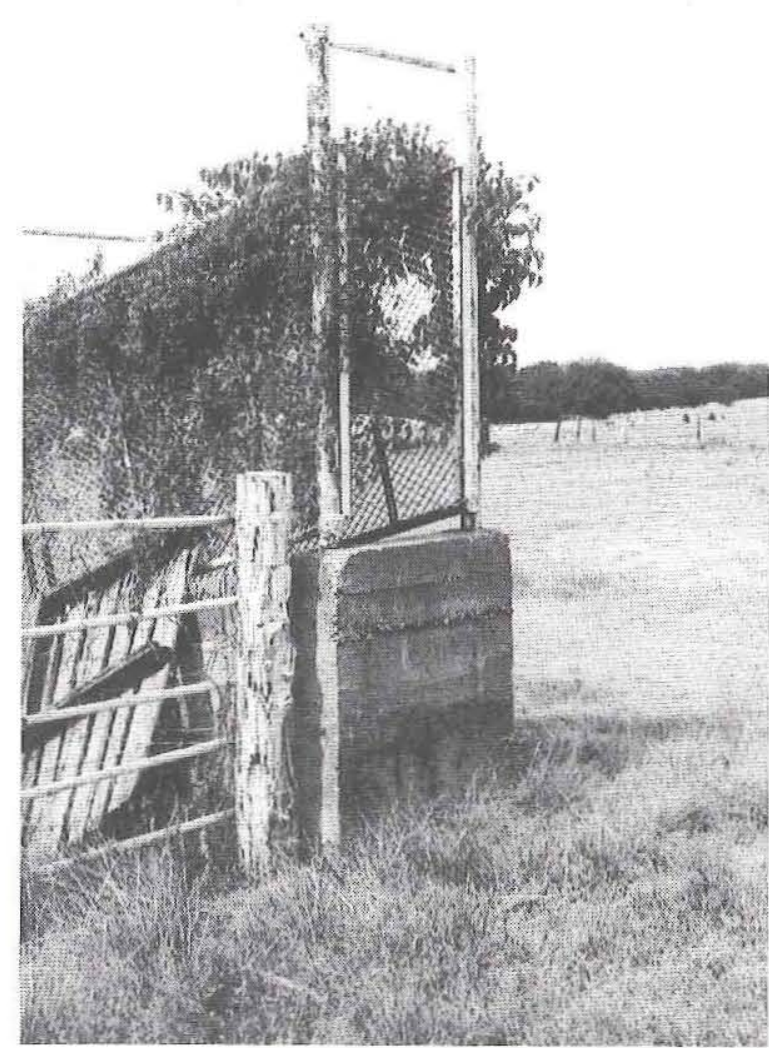

Figure 52. View to the northeast of Historic Resource No. 36 , livestock chute.

farm's agricultural operations. It retains a high degree of integrity and is recognizable to its date of construction. For these reasons, it is recommended that the chute be considered eligible for listing in the National Register of Historic Places under Criterion $\mathrm{A}$ as a Contributing property within the State Dairy and Hog Farm Administrative, Residential, and Dairy Operations Historic District and for designation as a State Archeological Landmark. 



\section{ASSESSMENTS AND RECOMIMENDATIONS}

The cultural resources investigations at the Leander Rehabilitation Center documented one prehistoric archeological site, four historic archeological sites, and 45 buildings and structures. None of the archeological sites are considered eligible for listing in the National Register of Historic Places or for designation as State Archeological Landmarks. Twenty-one of the buildings and structures are recommended as eligible for listing in the National Register as Contributing resources in a historic district and for designation as State Archeological Landmarks.

Cultural resources are eligible for listing in the National Register of Historic Places, and thus are worthy of avoidance, protection, or mitigation through data recovery, if they are significant in American history, architecture, engineering, or culture (National Park Service 1991:2). Significant properties are those that:

possess integrity of location, design, setting, materials, workmanship, feeling, and association, and

A. that are associated with events that have made a significant contribution to the broad patterns of our history; or

B. that are associated with the lives of persons significant in our past; or

C. that embody the distinctive characteristics of a type, period, or method of construction, or that represent the works of a master, or that possess high artistic values, or that represent a significant and distinguishable entity whose components may lack individual distinction; or
D. that have yielded or may be likely to yield information important in prehistory or history [National Park Service 1991:2].

Criterion D is most relevant to prehistoric archeological resources. Potentially, all four criteria may apply to historic archeological sites. However, with a single exception, the historic archeological sites reported here lack standing structures or association with historically important persons or events, and they are evaluated only in terms of Criterion D. All four criteria may apply to the architectural resources. These four criteria also are used here to assess the resources in terms of their eligibility for designation as State Archeological Landmarks.

\section{ARCHEOLOGICAL RESOURCES}

Prehistoric site $41 \mathrm{WM} 452$ is an extensive upland lithic scatter and lithic procurement site. The collection of Pedernales and Marshall dart points suggest that the site was utilized during the Late Archaic period, and it is likely that it was used during other periods as well. The fact that the site is surficial, or nearly so, indicates that identifying and isolating discrete components would be impossible. The site also lacks intact features with datable materials. Due to these contextual problems, the archeological remains do not have the capacity to contribute important information concerning the prehistory of the region. Therefore, it is recommended that $41 \mathrm{WM} 452$ be considered not eligible for listing in the National Register of Historic Places or for designation as a State Archeological Landmark.

Historic site 41WM892 is a wood-chopper camp 
consisting of three campsites/activity areas, and it may contain a component associated with an unidentified African American occupant as well. This camp was used for corporate activity from 1905 to 1908. The site retains some of its surface features in the form of rock alignments, and it has limited artifact deposits. However, the site is surficial and does not have the capacity to yield data other than that already recorded during this project. Because it cannot contribute important information and is of low integrity, it is recommended that 41WM892 be considered not eligible for listing in the National Register of Historic Places or for designation as a State Archeological Landmark.

Historic site 41 WM893 is the remnant of a railroad spur used during the 1937-1941 construction of Marshall Ford Dam (now Mansfield Dam). Besides the railroad bed itself, there are no associated features or artifacts that would yield further information about activities at this location. There is no stratified archeological deposit, and the integrity of the site is low. Further examination of this railroad spur would yield little beyond what is already known from archival sources; therefore, it is recommended that 41WM893 be considered not eligible for listing in the National Register of Historic Places or for designation as a State Archeological Landmark.

Historic site 41WM896, the Rhodes farm, is a farmstead complex occupied and used from 1937 to 1945. Several poured concrete surface features remain and represent parts of both the house area and the livestock/farm area, but artifacts that can be related to the occupation are very scarce. Further, the farmstead was modified substantially and reused during the years that the project area functioned as the State Dairy and Hog Farm. Because of the sparseness of artifacts and the lack of integrity, the site has little potential to yield important information. Therefore, it is recommended that 41WM896 be considered not eligible for listing in the National Register of Historic Places or for designation as a State Archeological Landmark.

Historic site 41WM897 is an isolated well of an unknown, pre-1940s date. The well is an adaptation of a natural spring. Most likely this well was associated with the Dedear family farmstead or another previous landowner. The lack of artifacts and other features (either surface or subsurface) suggests that this well was not associated with a dwelling. Archival information supports this conclu- sion, since no record of a habitation in this area was found. As an isolated feature with uncertain associations, the site has little potential to yield important information. Hence, it is recommended that 41 WM897 be considered not eligible for listing in the National Register of Historic Places or for designation as a State Archeological Landmark.

\section{ARCHITECTURAL RESOURCES}

Of the 45 buildings and structures surveyed at 36 locations, 24 are recommended as being not eligible for listing in the National Register of Historic Places or for designation as State Archeological Landmarks because they have lost integrity of materials, association, feeling, and setting, or they are not yet 50 years old and do not meet the National Register criteria exceptions. The 24 ineligible buildings and structures are Historic Resources Nos. 6a, 6b, 8, 18-25a, 26-32f, and 35 .

The remaining 21 buildings and structures are recommended as being eligible for listing in the National Register of Historic Places under Criteria A and/or $\mathrm{C}$ as Contributing Resources to the State Dairy and Hog Farm Administrative, Residential, and Dairy Operations Historic District; these 21 also are recommended as being eligible for designation as State Archeological Landmarks. The period of significance for this district is 1942-1951. Figure 53 shows the recommended district and resources, and Table 3 lists the buildings and structures included. None of the buildings or structures identified as Contributing to the district are sufficiently distinguished architecturally to be considered individually eligible for the National Register, nor are one or more dominant within the history of the State Dairy and Hog Farm. Rather, they are recommended as being eligible as a group because of their collective presence and their ability to provide a strong, tangible link with the initial phase of operations and development of the State Dairy and Hog Farm.

The district retains a high degree of integrity. The original administrative, residential, and dairy operations portion of the facility contained 29 buildings and structures built between 1942 and 1951 , as well as a house associated with the Dedear family, which occupied the site prior to the purchase of the land by the state. Of these, a dairy barn (1943), a hay shed (1943), a barn built at Longhorn Cavern State Park by the Civilian Conservation 


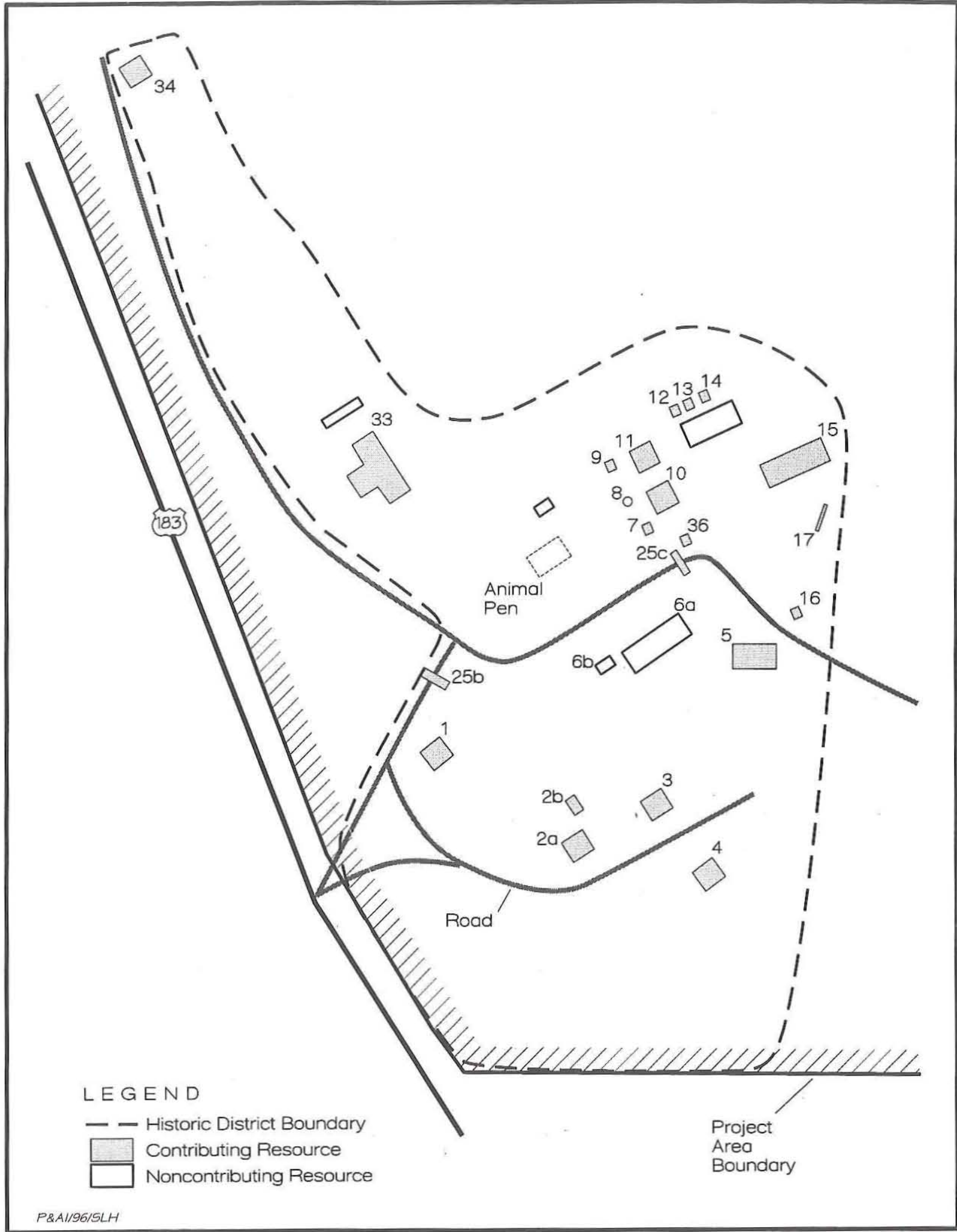

Figure 53. Recommended State Dairy and Hog Farm Administrative, Residential, and Dairy Operations Historic District (Noncontributing resources with numbers were surveyed; those without numbers were not surveyed because they are less than 50 years old). 
TABLE 3

CONTRIBUTING RESOURCES WITHIN THE STATE DAIRY AND HOG FARM ADMINISTRATIVE, RESIDENTIAL, AND DAIRY OPERATIONS HISTORIC DISTRICT

\begin{tabular}{|c|c|l|c|}
\hline Historic Resource No. & Building No. & Function & Date \\
\hline 1 & $600 / 8120$ & Storekeeper/accountant's office and warehouse & 1943 \\
$2 \mathrm{a}$ & $? / 8127$ & Superintendent's residence & 1946 \\
$2 \mathrm{~b}$ & $618 / ?$ & Garage at Superintendent's residence & 1946 \\
3 & $626 / 8128$ & Storekeeper/accountant's residence & 1945 \\
4 & $627 / 8129$ & Dairyman's residence & 1945 \\
5 & $?$ & Maintenance barn & 1950 \\
7 & $?$ & Water trough & 1943 \\
9 & $?$ & Water trough & 1943 \\
10 & $? / 8123$ & Bull barn & 1943 \\
11 & $? / 8124$ & Mule barn & 1943 \\
12 & $?$ & Calf feeder shed & 1950 \\
13 & $?$ & Calf feeder shed & 1950 \\
14 & $?$ & Calf feeder shed & 1950 \\
15 & $?$ & Feed trough & 1950 \\
16 & $?$ & Water trough & 1943 \\
17 & $?$ & Fencing & 1943 \\
$25 \mathrm{~b}$ & $?$ & Culvert & 1943 \\
$25 \mathrm{c}$ & $?$ & Culvert & 1943 \\
33 & $?$ & Kitchen/dining room/dormitory & 1943 \\
34 & $?$ & Sewage treatment facility & 1943 \\
36 & Cattle chute & 1950 \\
\hline
\end{tabular}

(1943), a hay shed (1943), a barn built at Longhorn Cavern State Park by the Civilian Conservation Corps prior to 1942 and moved to the State Dairy and Hog Farm about 1950, the Dedear farmhouse (ca. 1937), two water towers (ca. 1943), a woodframe kitchen and dining room (ca. 1948), a woodframe house (ca. 1948), and a duplex (ca. 1950) have been demolished. A hay barn just south of Historic Resources Nos. 12-14, also a Civilian Conservation Corps building from Longhorn Cavern State Park, has collapsed and is in ruins; it was not surveyed during this project and is considered Noncontributing to the historic district. Also considered Noncontributing are four buildings and structures built after 1951 (three recorded as Historic Resources Nos. 6a, 6b, and 8 and one, just north of Historic Resource No. 33, that was not surveyed) and an animal pen constructed of chain-link fencing. The 21 surviving resources are those recommended for National Register eligibility (see Table 3 ).

\section{Criterion A}

The State Dairy and Hog Farm was a swine and dairy operation that began in 1942, expanded after 1945 , and reached its height of production as a hog farm between 1950 and the late 1960s. The facility was created in response to the threatened closure of the Austin abattoir, the scarcity of food products during World War II and desire of the State Board of Control to make eleemosynary institutions in Austin self-sufficient, and a need to relieve overcrowding in the State hospital. The State Dairy and Hog Farm derives its significance from the success it achieved in food production, eventually producing meat not only for Austin's institutions but for others in the state. It also is significant because it appears to have been the only permanent eleemosynary facility constructed by order of the State Board of Control during World War II. Finally, the farm is important for the role it played in facilitating not only institutional self-sufficiency, but also client selfsufficiency through the application of modern psychiatric treatment based on the therapeutic value of manual labor.

The 21 extant resources built between 1942 and 1951 are significant at the statewide level under Criterion A for their associations with the initial 
operations of the State Dairy and Hog Farm (1942-1945) and the subsequent expansion of the combined dairy and hog operations (1946-1951). The three brick houses served as residences for the facility's management employees, the kitchen-dining room-dormitory housed patients who worked at the farm and provided facilities for feeding them, and the storekeeper/accountant's office and warehouse served as the administration facility for the farm's operations. The concrete Imhoff tank, a type of septic system widely used in the United States, was the sewage treatment plant for the farm. The culverts are part of the infrastructural system, along with the Imhoff tank, and represent the engineering technology in use for the management of sewage and storm runoff during the early twentieth century. The residences, the office-warehouse, and the dormitory are of primary significance. The Imhoff tank, the culverts, and the garage are of secondary significance.

The three residences, the storekeeper/accountant's office, the kitchen-dining room-dormitory, and the Imhoff tank, along with the wood-frame garage and the two poured-in-place concrete culverts, represent the first permanent buildings at the facility and provide tangible links to the formative period in its history. Built between 1943 and 1946, they were the nucleus for the dairy operations, which was adjacent to the residential-administrative area of the facility. The dairy operations revolved around the dairy barn (now demolished) and included a variety of pens, troughs, and barns. Two concrete water troughs, two wood-frame barns, and some wire fencing survive from the period of initial dairy operations. These agricultural resources are significant because they are associated with the initial operations of the farm. They are of secondary significance, however, since they played supporting roles to the dairy barn in those operations.

At the end of World War II, the state expanded the dairy and hog operations at the farm; as a result, additional resources were constructed to serve the growing agricultural requirements of the facility. Between 1946 and 1951, additional buildings and structures were erected in the vicinity of the dairy barn and the other dairy-related buildings and structures to serve the dairy operations. These include barns, sheds, chutes, and troughs. Six survive and are recommended for inclusion in the historic district. In 1951, dairy operations were phased out and hog operations were expanded.
Buildings and structures associated with the original hog operations, which began in 1942, were located north of the administrative, residential, and dairying portions of the farm on the Dedear tract to the southeast of the Rhodes tracts. These all have been demolished. Only six of the properties associated with the first expansion of hog operations (1946-1951) survive. These are fragmentary remains dating from about 1950 located southeast of the dairying complex. They include two pole sheds, two feed troughs, and two water troughs that have lost their integrity of setting, association, and feeling. Because they are fragmentary and are physically isolated from the original hog and dairying operations, they are recommended as being ineligible for listing in the National Register or for designation as State Archeological Landmarks. Reflecting the ongoing expansion of the swine operation after 1951, a number of buildings and structures were erected about 1955 on the Rhodes tract just northwest of the 1946-1951 swine complex. These resources consist of a row of six pole barns converted to dormitories, a kitchen-laundry-restroom facility, and a concrete sewer pipe. Initially thought to date to the late 1940s, informant testimony revealed they were built about 1955 . Thus, they are not associated with the historic period and are not eligible for listing in the National Register of Historic Places. Other resources, including the drinking fountain in the dairy operations area of the farm, also received a date and National Register eligibility reevaluation based on informant testimony.

\section{Criterion C}

In addition, the three residences, the storekeeper/accountant's office, the kitchen-dining roomdormitory, and the Imhoff tank are potentially eligible at the local level under Criterion C. Because materials were in short supply during World War II, with metal and wood especially scarce, the designer of these resources specified more-available materials - brick and concrete- that during peacetime were significantly more costly. Information from the 1946 budget for the facility notes that approximately $\$ 1,000$ more in construction costs was anticipated for the Superintendent's house due to peacetime inflation (State Board of Control, Box 1991/16-65). The facility's architect, Walter C. Moore, Jr., an employee of the State Board of Control, apparently utilized an established engineer- 
ing design for the concrete Imhoff tank. Moore utilized cavity-wall construction for the brick houses, the brick office-warehouse, and the brick kitchendining room-dormitory. Although common in institutional design during the 1930 s and later, this construction method may be unusual, even rare, in small-scale buildings and residences such as those at the State Dairy and Hog Farm. Department of Mental Health and Mental Retardation designers undoubtedly were familiar with this construction method and its use in larger-scale institutional buildings. It is interesting that Moore utilized a familiar technology and acquired available materials to design the permanent features of the farm during a national emergency. Cavity-wall construction in these small-scale buildings indicates a creative approach to the problem of construction during and immediately after the war and familiarity with thencurrent design theory and trends.

The brick buildings also may be significant as examples of early Ranch-style architectural design. Developed in the late 1930 s but not widely built until after World War II, the Ranch style came to be the design of choice for millions of houses in postwar subdivisions across the country. It is representative of the major social changes that occurred in American society after the war. The appearance of designs utilizing Ranch-style elements at the State Dairy and Hog Farm as early as 1943 is another indication that the facility's designer was well versed in current architectural theory and was forward thinking. Interestingly, the eaves are embellished with wood knee braces of the type most often found on Craftsman bungalows of the 1910s and 1920s. The use of the knee braces suggests the need to temper new design concepts with familiar elements, thus making the buildings more visually acceptable to their users. The Imhoff tank may be significant as a local example of a widely used engineering technology common in the early and mid twentieth century.

\section{Mitigation Recommendations}

If plans call for the removal or demolition of the 21 buildings and structures assessed as being eligible for listing in the National Register and for designation as State Archeological Landmarks, it is recommended that their loss be mitigated through Historic American Buildings Survey (HABS) documentation. Because original plans for the brick buildings and the Imhoff tank have not survived, HABS Level I documentation may be warranted for those buildings. This consists of preparing site plans and details, preparing measured drawings of each building and structure, taking large-format black-andwhite photographs, and preparing a historic narrative and description of the resources. It is recommended that the other resources be documented at HABS Level IV. This report and the supporting records can provide a significant portion of the materials that will be needed for both HABS Level I and HABS Level IV documentation, although additional photography and measured drawings, as well as preparation of forms according to HABS specifications, would be required. 


\section{BIBLIOGRAPHY}

Albritton, Elaine

1996 Telephone interview with Elaine Albritton, September 18, 1996 by Martha Doty Freeman, Austin, Texas.

Austin American-Statesman

Austin American, The

Austin Statesman, The

Austin History Center

AF, Municipal Buildings, M8640(2) Abattoir

Babbit, Harold E.

1953 Sewerage and Sewage Treatment. John Wiley \& Sons, Inc., New York.

Banks, James H. (Jimmy), and John E. Babcock

1988 Corralling the Colorado: The First Fifty Years of the Lower Colorado River Authority. Eakin Press, Austin, Texas.

Barnes, Virgil E. (project director)

1981 Geologic Atlas of Texas, Austin Sheet. Bureau of Economic Geology, The University of Texas at Austin.

Black, Stephen L.

1989 Central Texas Plateau Prairie. In From the Gulf to the Rio Grande: Human Adaptations in Central, South, and Lower Pecos, Texas, by Thomas R. Hester, Stephen L. Black, D. Gentry Steele, Ben W. Olive, Anne A. Fox, Karl J. Reinhard, and Leland C. Bement, pp. 17-38. Research Series 33. Arkansas Archeological Survey, Fayetteville.
Blair, W. Frank

1950 The Biotic Provinces of Texas. The Texas Journal of Science 2(1):93-117.

Boland, Beth Grosvenor

1991 Guidelines for Evaluating and Documenting Properties Associated with Significant Persons. National Register Bulletin 32. U.S. Department of the Interior, National Park Service, Interagency Resources Division, Washington, D.C.

Bolton, Herbert E.

1915 Texas in the Middle Eighteenth Century: Studies in Spanish Colonial History and Administration. University of California Press, Berkeley,

Briggs, Alton K:

1983 An Archeological and Historical Survey of the Buttercup Creek Subdivision, SD3290, Section 3, Village 1, Cedar Park, Williamson County, Texas. Report submitted to the Texas Historical Commission, Austin.

Bryant, Douglas Donne

1985 Cultural Resources Survey of the Proposed Leander Development Area, Williamson County, Texas. Submitted to Lichliter/Jameson and Associates, Inc., Austin, Texas, by Coastal Environments, Inc., Baton Rouge, Louisiana.

Campbell, T. N.

1988 Indians of Southern Texas and Northeastern Mexico: Selected Writings of Thomas Nolan Campbell. Texas Archeological Research Laboratory, The University of Texas at Austin. 
Campbell, T. N., and T. J. Campbell

1981 Historic Indian Groups of the Choke Canyon Reservoir and Surrounding Area, Southern Texas. Choke Canyon Series I. Center for Archaeological Research, The University of Texas at San Antonio.

Coffman, Robert J., Martha Doty Freeman, and Ross C. Fields

1985 Inventory and Assessment of Cultural Resources at the Ideal Basic Tract, Williamson County, Texas. Reports of Investigations 38. Prewitt and Associates, Inc., Austin.

Cavness, C. H.

[1948] Audit Report, Austin State Hospital, Austin, Texas, Sept. 1, 1941-Jan. 31, 1948. Office of the State Auditor, Austin.

Coffman, Robert J., and Elton R. Prewitt

1985 Phase 2 Cultural Resources Investigations in Portions of the Buttercup Creek Subdivision, Williamson County, Texas. Reports of Investigations 36. Prewitt and Associates, Inc., Austin.

Collins, Michael B.

1990 The Archeological Sequence at Kincaid Rockshelter, Uvalde County, Texas. Transactions of the Twenty-fifth Regional Archeological Symposium for Southeastern New Mexico and Western Texas, pp. 25-34.

1995 Forty Years of Archeology in Central Texas. Bulletin of the Texas Archeological Society 66:361-400.

Collins, Michael B., Bruce Ellis, and Cathy Dodt-Ellis

1990 Excavations at the Camp Pearl Wheat Site (41KR243): An Early Archaic Campsite on Town Creek, Kerr County, Texas. Studies in Archeology 6. Texas Archeological Research Laboratory, The University of Texas at Austin.

Collins, Michael B., Thomas R. Hester, and

Pamela J. Headrick

1992 Engraved Cobbles from the Gault Site, Central Texas. Current Research in the Pleistocene 9:3-4.

DeBolt, Gerald C.

1988 The Dictionary of American Pottery Marks:
Whiteware and Porcelain. Charles E. Tuttle Company, Rutland, Vermont.

Department of Mental Health and Mental Retardation. Asset Management

Files: Ownership Records

File : Leander Rehabilitation Center

File : Leases, Permits and Licenses

Fields, Ross C., Martha Doty Freeman, and Robert J. Coffman

1985 Inventory and Assessment of Cultural Resources at the Cypress Mill Joint Venture Tract, Williamson and Travis Counties, Texas. Reports of Investigations 37. Prewitt and Associates, Inc., Austin.

Foster, L. L.

1889 First Annual Report of the Agricultural Bureau of the Department of Agriculture, Insurance, Statistics, and History, 1887-88. State Printing Office, Austin, Texas.

Fox, Daniel E.

1979 The Lithic Artifacts of Indians at the Spanish Colonial Missions, San Antonio, Texas. Special Report No. 8. Center for Archaeological Research, The University of Texas at San Antonio.

Fox, Daniel E., and W. Hayden Whitsett

1984 Archeological Reconnaissance along South Brushy Creek, near the City of Cedar Park, Williamson County, Texas. Construction Grants and Water Quality Management Division, Texas Department of Water Resources, Austin.

Garner, L. E., and K. P. Young

1976 Environmental Geology of the Austin Area: An Aid to Urban Planning. Reports of Investigations No. 86. Bureau of Economic Geology, The University of Texas at Austin.

Gates, William C., Jr., and Dana E. Ormerod

1982 The East Liverpool Pottery District: Identification of Manufacturers and Marks. Historical Archaeology 16:1-2.

General Land Office (Texas)

1847 Milam 1st class, file 179, abstract 551. Patented September 16, 1847, by Joseph M. Glasscock. 
Goode, Glenn T.

1991 Late Prehistoric Burned Rock Middens in Central Texas. In The Burned Rock Middens of Texas: An Archeological Symposium, edited by Thomas R. Hester, pp. 71-93. Studies in Archeology 13. Texas Archeological Research Laboratory, The University of Texas at Austin.

Hall, Bernard H. (editor)

1959 A Psychiatrist's World: The Selected Papers of Karl Minninger, M.D. The Viking Press, Ney York.

Hester, Thomas R.

1989 Historic Native American Populations. In From the Gulf to the Rio Grande: Human Adaptation in Central, South, and Lower Pecos Texas by Thomas R. Hester, Stephen L. Black, D. Gentry Steele, Ben W. Olive, Anne A. Fox, Karl J. Reinhard, and Leland C. Bement, pp. 77-84. Research Series 33. Arkansas Archeological Survey, Fayetteville.

Hill, R. T.

1901 Geography and Geology of the Black and Grand Prairies, Texas, with Detailed Description of the Cretaceous Formations and Special Reference to Artesian Waters. Twenty-first Annual Report of the United States Geological Survey 1899-1900, Part 7-Texas.

Howard, Margaret A.

1983 An Archeological Survey of the Proposed Springwoods II-G Subdivision, Williamson County, Texas. Letter Report No. 206. Prewitt and Associates, Inc., Austin.

Howard, Margaret A., and Jack Jackson

1984a An Archeological Survey of the Nash Phillips/ Copus The Woods Subdivision, Williamson County, Texas. Letter Report 264. Prewitt and Associates, Inc., Austin.

1984b An Archeological Survey of the Los Indios Subdivision, Phases $A$ and $B$, Williamson County, Texas. Letter Report 268. Prewitt and Associates, Inc., Austin.

Hubbard, Richard A., David O. Brown, and Jack M. Jackson

1984 A Cultural Resources Survey and Assessment of the North Austin Municipal Utility District No. 1, Williamson and Travis County, Texas. Report submitted to the Bill Milburn Company, Austin.

Huebner, Jeffery A.

1991 Late Prehistoric Bison Populations in Central and South Texas. Plains Anthropologist 36(137):343-358.

International Text Book Company

1899 International Library of Technology: Masonry, Carpentry, Joinery. Scranton, Pennsylvania.

Jelks, Edward B.

1962 The Kyle Site: A Stratified Central Texas Aspect Site in Hill County, Texas. Archaeology Series, No. 5, Department of Anthropology, The University of Texas, Austin.

Johnson, LeRoy, and Glenn T. Goode

1994 A New Try at Dating and Characterizing Holocene Climates, as Well as Archeological Periods, on the Eastern Edwards Plateau. Bulletin of the Texas Archeological Society 65:1-51.

Johnson, Elmer H.

1931 The Natural Regions of Texas. Monograph No. 8. Bureau of Business Research, The University of Texas at Austin.

Jones, Roy,

1996 Personal Interview with Roy Jones, Facilities Manager, Texas Department of Mental Health and Mental Retardation, September 6, 1996, by Diane E. Williams, Austin, Texas.

Kibler, Karl W., and Karen M. Gardner

1994 Archeological Survey and National Register Testing at 41BX377, Camp Bullis Military Reservation, Bexar and Comal Counties, Texas. Review Draft. Reports of Investigations No. 101. Prewitt and Associates, Inc., Austin.

Lehner, Lois

1988 Lehner's Encyclopedia of U.S. Marks on Pottery, Porcelain \& Clay. Collector Books, Paducah, Kentucky. 
Masson, Marilyn A., and Michael B. Collins

1995 The Wilson-Leonard Site (41WM235). Cultural Resource Management News and Views 7(1):6-10. Texas Historical Commission, Austin.

McGraw-Hill, Inc.

1992 McGraw-Hill Encyclopedia of Science and Technology, Volume 9. McGraw-Hill, Inc., New York.

McKinney, Wilson W.

1981 Early Holocene Adaptations in Central and Southwestern Texas: The Problem of the Paleoindian-Archaic Transition. Bulletin of the Texas Archeology Society 52:91-120.

Mercado-Allinger, Patricia A., Elton R. Prewitt, and Crystal Sasse Ragsdale

1984 Inventory and Assessment of Cultural Resources in Portions of the Buttercup Creek Subdivision, Williamson County, Texas. Reports of Investigations 30. Prewitt and Associates, Inc., Austin.

Mercado-Allinger, Patricia A., and Crystal Sasse Ragsdale 1984 Inventory and Assessment of Cultural Resources, Jamail Property Development, Williamson County, Texas. Reports of Investigations 28. Prewitt and Associates, Inc., Austin.

Merritt, Frederick S. (editor)

1968 Standard Handbook for Civil Engineers. McGraw-Hill, Inc., New York.

National Park Service

1991 How to Apply the National Register Criteria for Evaluation. National Register Bulletin 15. U.S. Department of the Interior, National Park Service, Interagency Resources Division, Washington, D.C.

Newcomb, W. W., Jr.

1961 The Indians of Texas. The University of Texas Press, Austin.

Nordt, Lee C., Thomas W. Boutton, Charles T. Hallmark, and Michael R. Waters

1994 Late Quaternary Vegetation and Climate Changes in Central Texas Based on the Isotopic Composition of Organic Carbon. Quaternary Research 41:109-120.
Pearce, J. E.

1919 Indian Mounds and Other Relics of Indian Life in Texas. American Anthropologist 21(3):223-234.

1928- Reports on Yearly Works - Pearce Project.

1938 Ms. on file, Texas Archeological Research Laboratory, The University of Texas at Austin.

Prewitt, Elton R.

1981 Cultural Chronology in Central Texas. Bulletin of the Texas Archeological Society 52:65-89.

1985 From Circleville to Toyah: Comments on Central Texas Chronology. Bulletin of the Texas Archeological Society 54:201-238.

Ramsey, Charles George, AIA, and Harold Reeve Sleeper, AIA.

1936 Architectural Graphic Standards for Architects,

(1951) Engineers, Decorators, Builders and Draftsmen. John Wiley \& Sons, Inc., New York.

Scarbrough, Clara Stearns

1980 Land of Good Water, Takachue Poustru: A Williamson County, Texas, History. Williamson County Sun Publishers, Georgetown, Texas.

State Board of Control (Texas)

Records of the Board of Control in the collections of the Texas State Library and Archives, Austin, Texas.

Box'1991/16-9

Box 1991/16-12

Box 1991/16-18

Box 1991/16-31

Box 1991/16-32

Box 1991/16-40

Box 1991/16-44

Box 1991/16-53

Box 1991/16-56

Box 1991/16-65

Box 1991/16-84

Box 1991/16-85

[1947] Thirteenth Biennial Appropriation Budget [,] State of Texas[.] Prepared by the State Board of Control and Submitted by the Governor to the Forty-Ninth Legislature for Biennium Beginning September 1, 1945, Ending August 31, 1947. Von Boeckmann-Jones Co., Austin, Texas. 
Story, Dee Ann

1985 Adaptive Strategies of Archaic Cultures of the West Gulf Coastal Plain. In Prehistoric Food Production in North America, edited by R. I. Ford, pp. 19-56. Anthropological Papers 75. Museum of Anthropology, University of Michigan, Ann Arbor.

Strong, Julie W., Amy C. Earls, Karl W. Kibler, Joe C. Freeman, and Ross C. Fields

1996 Cultural Resources Assessment for the Salt Creek Flood Protection Feasibility Study, Young County, Texas. Review Draft. Reports of Investigations No. 106. Prewitt and Associates, Inc., Austin.

Texas State Historical Association

1996 The New Handbook of Texas. 6 vols. Texas State Historical Association, Austin, Texas.

Toomey III, Rickard S., Michael D. Blum, and Salvatore Valastro Jr.

1993 Late Quaternary Climates and Environments of the Edwards Plateau, Texas. Global and Planetary Change 7:299-320.

Urgurhart, Leonard Church

1950 Civil Engineering Handbook. McGraw-Hill, Inc., New York.

U.S. Department of the Interior

1910 Texas Austin Quadrangle.

Voellinger, Leonard R., and Christian Nightengale

1985 A Cultural Resources Survey of the Block House Creek Development, Williamson County, Texas. Document No. 84930. Espey, Huston and Associates, Inc., Austin.
Webb, Walter Prescott (editor)

1952 The Handbook of Texas. 3 vols. Texas State Historical Association, Austin.

Weir, F. A.

1976 The Central Texas Archaic. Unpublished $\mathrm{Ph} . \mathrm{D}$. dissertation, Department of Anthropology, Washington State University, Pullman.

Werchan, Leroy E., and John L. Coker

1983 Soil Survey of Williamson County, Texas. United States Department of Agriculture, Soil Conservation Service in cooperation with Texas Agricultural Experiment Station.

Williamson County

Deed Records

Deed of Trust Records

Williamson County Sun, The

Whitsett, W. Hayden

1981 An Archeological Reconnaissance at Cedar Park, Williamson County. C-48-1524-01. Construction Grants and Water Quality Planning Division, Texas Department of Water Resources, Austin.

Willey, Gordon R., and Philip Phillips

1958 Method and Theory in American Archaeology. University of Chicago Press, Chicago.

Wynn, Mr. and Mrs. Leonard, and Elaine Wynn Albritton 1996 Personal interview Mr. and Mrs. Leonard Wynn and Elaine Wynn Albritton, September 7, 1996 by Martha Doty Freeman and Diane E. Williams, the State Dairy and Hog Farm, Williamson County, Texas. 


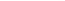


APPENDIX: Inventory of Buildings and Structures 



\begin{tabular}{|c|c|c|c|c|c|c|c|c|c|c|c|c|c|c|c|c|c|c|c|}
\hline \multicolumn{2}{|c|}{ Resource Identification } & \multicolumn{13}{|c|}{ Resource Description } & \multicolumn{5}{|c|}{ Evaluation } \\
\hline ID. No. & Building Number & $\begin{array}{c}\text { Construction } \\
\text { Date }\end{array}$ & $\begin{array}{c}\text { Averation } \\
\text { Date }\end{array}$ & Porch & Window & Door & $\begin{array}{l}\text { Ederior } \\
\text { Siding }\end{array}$ & Adétions & $\begin{array}{l}\text { Condition } \\
E=G-F-P-R \\
\end{array}$ & $\begin{array}{c}\text { Resource } \\
\text { Type }\end{array}$ & $\begin{array}{c}\text { Property } \\
\text { Type }\end{array}$ & Property Subtype & Sories & Exterior Materials & $\mathrm{H}$ & $S M$ & $\mathrm{M}$ & sL & $L$ \\
\hline 1 & $600 / 8120$ & 1943 & 1965 & $\mathrm{x}$ & $x$ & & & $x$ & $F$ & B & OS & \begin{tabular}{|l} 
office and \\
warehouse
\end{tabular} & 1 & brick & & $\mathrm{X}$ & & & \\
\hline $2 a$ & $? / 8127$ & 1946 & & & & & & & $F$ & $\mathrm{~B}$ & DS & $\begin{array}{l}\text { side-gabled } \\
\text { bungalow }\end{array}$ & 1 & brick/wood & & $x$ & & & \\
\hline $2 b$ & $618 / ?$ & 1946 & & & & & & & $P$ & $B$ & $D A$ & garage & 1 & wood & & & $\mathrm{x}$ & & \\
\hline 3 & $626 / 8128$ & 1945 & & & & & & & $F$ & $\mathrm{~B}$ & DS & $\begin{array}{l}\text { side-gabled } \\
\text { bungalow }\end{array}$ & 1 & brick/wood & & $x$ & & & \\
\hline 4 & $627 / 8129$ & 1945 & 1965 & & & & & $x$ & $F$ & $B$ & DS & $\begin{array}{l}\text { side-gabled } \\
\text { bungalow }\end{array}$ & 1 & brick/wood & & & $x$ & & \\
\hline 5 & $?$ & 1950 & & & & & & & $\mathrm{~F}$ & $B$ & $\mathrm{Ag}$ & barn & 1 & corrugated metal & & & $x$ & & \\
\hline $6 a$ & $? / 8135$ & 1955 & & & & & & & $\mathrm{P}$ & $\mathrm{B}$ & $\mathrm{Ag}$ & barn & 1 & corrugated metal & & & & $x$ & \\
\hline $6 b$ & $?$ & 1955 & & & & & & & $\mathrm{~F}$ & St & $\mathrm{Ag}$ & scale & 1 & corrugated metal & & & & $\mathrm{x}$ & \\
\hline 7 & $?$ & 1943 & & & & & & & $\mathrm{~F}$ & St & $\mathrm{Ag}$ & water trough & & concrete & & & $x$ & & \\
\hline 8 & $?$ & 1970 & & & & & & & $F$ & St & Infra & water fountain & & metal & & & & & $x$ \\
\hline 9 & $?$ & 1943 & & & & & & & $F$ & St & $\mathrm{Ag}$ & water trough & & concrete & & & $x$ & & \\
\hline 10 & $? / 8123$ & 1943 & & & & & $x$ & & $F$ & B & $\mathrm{Ag}$ & pole barn & 1 & wood & & & $x$ & & \\
\hline 11 & $? / 8124$ & 1943 & & & & & & $x$ & $F$ & B & $\mathrm{Ag}$ & pole barn & 1 & wood & & & $\mathrm{x}$ & & \\
\hline 12 & $?$ & 1950 & & & & & & & $\mathrm{~F}$ & St & $\mathrm{Ag}$ & calf feeder shed & & wood & & & $x$ & & \\
\hline 13 & $?$ & 1950 & & & & & & & $F$ & St & $\mathrm{Ag}$ & calf feeder shed & & wood & & & $x$ & & \\
\hline 14 & $?$ & 1950 & & & & & & & $F$ & St & $\mathrm{Ag}$ & calf feeder shed & & wood & & & $\mathrm{x}$ & & \\
\hline 15 & $?$ & 1950 & & & & & & & $\mathrm{~F}$ & St & $\mathrm{Ag}$ & feed trough & 1 & concrete & & & $x$ & & \\
\hline 16 & $?$ & 1943 & & & & & & & $\mathrm{~F}$ & St & $\mathrm{Ag}$ & water trough & & concrete & & & $\mathrm{x}$ & & \\
\hline 17 & $?$ & 1943 & & & & & & & $P$ & St & Infra & fence & & wood/metal & & & $\mathrm{x}$ & & \\
\hline 18 & $669 / 8144$ & 1955 & 1975 & $x$ & $x$ & $\mathrm{x}$ & $\mathrm{x}$ & & $\mathrm{F}$ & B & $\mathrm{Ag}$ & hog shed/dormitory & 1 & wood/corrugated metal & & & & & $x$ \\
\hline 19 & $670 / 8145$ & 1955 & 1975 & $\mathrm{x}$ & $x$ & $x$ & $x$ & $x$ & $P$ & B & $\mathrm{Ag}$ & hog shed/dormitory & 1 & wood/corrugated metal & & & & & $x$ \\
\hline 20 & $671 / 8146$ & 1955 & 1975 & $\mathrm{x}$ & $x$ & $x$ & $\mathrm{x}$ & & $\mathrm{F}$ & $B$ & $\mathrm{Ag}$ & hog shed/dormitory & 1 & wood/corrugated metal & & & & & $x$ \\
\hline 21 & $? / 8148$ & 1975 & & $x$ & $\mathrm{x}$ & $\mathrm{x}$ & $x$ & $\mathrm{x}$ & $\mathrm{P}$ & B & OS & $\begin{array}{l}\text { kitchen/laundry/ } \\
\text { restroom }\end{array}$ & 1 & corrugated metal/wood & & & & & $x$ \\
\hline 22 & $672 / 8147$ & 1955 & 1975 & $\mathrm{x}$ & $x$ & $x$ & $x$ & & $F$ & $B$ & $\mathrm{Ag}$ & hog shed/dormitory & 1 & corrugated metal/wood & & & & & $x$ \\
\hline 23 & $674 / 8149$ & 1955 & 1975 & $x$ & $x$ & $x$ & $x$ & $x$ & $F$ & B & $\mathrm{Ag}$ & hog shed/dormitory & 1 & corrugated metal/wood & & & & & $\underline{x}$ \\
\hline 24 & $675 / 8150$ & 1955 & 1975 & $\mathrm{x}$ & $\mathrm{x}$ & $\mathrm{x}$ & $\mathrm{x}$ & & $\mathrm{P}$ & B & $\mathrm{Ag}$ & hog shed/dormitory & 1 & corrugated metal/wood & & & & & $x$ \\
\hline
\end{tabular}




\begin{tabular}{|c|c|c|c|c|c|c|c|c|c|c|c|c|c|c|c|c|c|c|c|}
\hline Resour & Identification & & & & & & & & Resol & ce Descr & ption & & & & & Evalt & uatic & & \\
\hline ID. No. & Bullaling Number & $\begin{array}{l}\text { Construction } \\
\text { Desto }\end{array}$ & 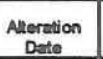 & Poren & Window & Door & $\begin{array}{l}\text { Exderlor } \\
\text { Siding }\end{array}$ & Adetitions & $\begin{array}{l}\text { Condtiton } \\
E \in G F-R-R\end{array}$ & $\begin{array}{c}\text { Rosource } \\
\text { Type }\end{array}$ & $\begin{array}{c}\text { Proposty } \\
\text { Tpen }\end{array}$ & Property Subtype & Storios & Exderior Materiale & $\mathrm{H}$ & $\sin 1$ & M & st & \\
\hline $25 a$ & $?$ & 1955 & & & & & & & $\mathrm{~F}$ & St & Infra & culvert & & concrete & & $\geq$ & $x$ & & \\
\hline $25 b$ & $?$ & 1943 & & & & & & & $\mathrm{~F}$ & St & Infra & culvert & & concrete & & & $\underline{x}$ & & \\
\hline $25 c$ & $?$ & 1943 & & & & & & & $F$ & St & Infra & culvert & & concrete & & & $\underline{x}$ & & \\
\hline 26 & $?$ & 1950 & & & & & & & $\mathrm{~F}$ & St & $\mathrm{Ag}$ & water trough & & concrete & & & $x$ & & \\
\hline 27 & $620 / 8126$ & 1950 & & & & & & & $\mathrm{P}$ & B & $\mathrm{Ag}$ & pole barn & 1 & corrugated metal/wood & & $\underline{\gamma}$ & $x$ & & \\
\hline 28 & $?$ & 1950 & & & & & & & $P$ & St & $\mathrm{Ag}$ & fencing & & concrete & & & & $x$ & \\
\hline 29 & $?$ & 1950 & & & & & & & $P$ & St & $\mathrm{Ag}$ & feed trough & & concrete/rock & & & $x$ & & \\
\hline 30 & $690 / 8162$ & 1950 & 1965 & & & & & & $\mathrm{~F}$ & B & $\mathrm{Ag}$ & pole barn & 1 & corrugated metal/wood & & & $x$ & & \\
\hline 31 & $?$ & 1950 & & & & & & & $\mathrm{~F}$ & St & $\mathrm{Ag}$ & feed trough & & concrete & & & $x$ & & \\
\hline $32 a$ & $?$ & 1951 & & & & & & & $\mathrm{~F}$ & B & DS & $\begin{array}{l}\begin{array}{l}\text { side-gabled } \\
\text { bungalow }\end{array} \\
\end{array}$ & 1 & wood & & $\underline{\gamma}$ & $x$ & & \\
\hline $32 b$ & $?$ & 1937 & & & & & & & $P$ & St & $\mathrm{Ag}$ & dip tank & & concrete & & & & $x$ & \\
\hline $32 c$ & $?$ & 1937 & & & & & & & $\mathrm{~F}$ & St & $\mathrm{Ag}$ & water trough & & concrete & & $\gamma$ & $x$ & & \\
\hline $32 d$ & $?$ & 1950 & & & & & & & $F$ & St & $\mathrm{Ag}$ & feed trough & 1 & concrete/metal & & $\underline{\gamma}$ & $\mathrm{x}$ & & \\
\hline $32 e$ & $?$ & 1945 & & & & & & & $\mathrm{~F}$ & St & $\mathrm{Ag}$ & water trough & & concrete & & $\underline{\gamma}$ & $x$ & & \\
\hline $32 f$ & $?$ & 1955 & & & & & & & $\mathrm{~F}$ & St & $\mathrm{Ag}$ & water trough & & concrete & & 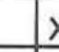 & 大 & & \\
\hline 33 & $602 / 8121$ & 1943 & 1975 & & & & & & $\mathrm{~F}$ & $B$ & DM & $\begin{array}{l}\text { kitchen/dining } \\
\text { room/dormitory }\end{array}$ & 1 & brick/wood & & & $x$ & & \\
\hline 34 & $?$ & 1943 & & & & & - & & $\mathrm{F}$ & St & Infra & $\begin{array}{l}\text { sewage treatment } \\
\text { facility }\end{array}$ & 1 & concrete & & $\underline{x}$ & K & & \\
\hline 35 & $?$ & 1955 & & & & & & & G & St & Infra & sewer pipe & & concrete & & $\underline{x}$ & $\mathrm{x}$ & & \\
\hline 36 & $?$ & 1950 & & & & & & & $\mathrm{~F}$ & St & $\mathrm{Ag}$ & livestock chute & & concrete & & $\underline{x}$ & $x$ & & \\
\hline
\end{tabular}

Key to Abbreviations:

$\begin{array}{ll}\text { Condition: } & \text { Resource Type: } \\ E=\text { Excellent } & \text { B }=\text { Building } \\ G=\text { Good } & \text { St }=\text { Structure } \\ F=\text { Fair } & S i=\text { Site } \\ P=\text { Poor } & \text { OB }=\text { Object } \\ R=\text { Ruin } & \end{array}$

Property Type:

OS = Operational Support

DS = Domestic Single

$D A=$ Domestic Auxiliary

$\mathrm{Ag}=$ Agricultural

Infra = Infrastructure

$\mathrm{DM}=$ Dormitory
Evaluation:

$\mathrm{H}=\mathrm{High}$

SM = Selected Medium

$M=$ Medium

$\mathrm{SL}=$ Selected $\mathrm{Low}$

$L=$ Low 

